\title{
Subduction and obduction processes in the Swiss Alps
}

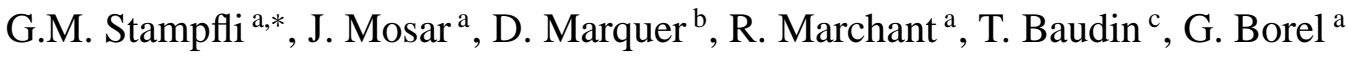 \\ ${ }^{a}$ Institut de Géologie et Paléontologie, Université de Lausanne, CH-1015 Lausanne, Switzerland \\ ${ }^{b}$ Institut de Géologie, Rue Emile Argand 11, CH-2007 Neuchatel, Switzerland \\ ${ }^{c}$ BRGM, 3 Avenue Claude Guillemin, B.P. 6009, 45060 Orleans cedex 2, France
}

\begin{abstract}
The significance of the Briançonnais domain in the Alpine orogen is reviewed in the light of data concerning its collision with the active Adriatic margin and the passive Helvetic margin. The Briançonnais which formerly belonged to the Iberian plate, was located on the northern margin of the Alpine Tethys (Liguro-Piémont ocean) since its opening in the early-Middle Jurassic. Together with the Iberian plate the Briançonnais terrane was separated from the European plate in the Late Jurassic-Early Cretaceous, following the northern Atlantic, Bay of Biscay, Valais ocean opening. This was accompanied by the onset of subduction along the northern margin of Adria and the closure of the Alpine Tethys. Stratigraphic and metamorphic data regarding this subduction and the geohistory of the Briançonnais allows the scenario of subduction-obduction processes during the Late Cretaceous-early Tertiary in the eastern and western Alps to be specified. HP-LT metamorphism record a long-lasting history of oceanic subduction-accretion, followed in the Middle Eocene by the incorporation of the Briançonnais as an exotic terrane into the accretionary prism. Middle to Late Eocene cooling ages of the Briançonnais basement and the presence of pelagic, anorogenic sedimentation lasting until the Middle Eocene on the Briançonnais preclude any sort of collision before that time between this domain and the active Adria margin or the Helvetic margin. This is confirmed by plate reconstructions constrained by magnetic anomalies in the Atlantic domain. Only a small percentage of the former Briançonnais domain was obducted, most of the crust and lithospheric roots were subducted. This applies also to domains formerly belonging to the southern Alpine Tethys margin (Austroalpine-inner Carpathian domain). It is proposed that there was a single Palaeogene subduction zone responsible for the Alpine orogen formation (from northern Spain to the East Carpathians), with the exception of a short-lived Late Cretaceous partial closure of the Valais ocean. Subduction in the western Tethyan domain originated during the closure of the Meliata ocean during the Jurassic incorporating the Austroalpine-Carpathian domain as terranes during the Cretaceous. The subduction zone propagated into the northern margin of Adria and then to the northern margin of the Iberian plate, where it gave birth to the Pyrenean-Provençal orogenic belt. This implies the absence of a separated Cretaceous subduction zone within the Austro-Carpathian Penninic ocean. Collision of Iberia with Europe forced the subduction to jump to the SE margin of Iberia in the Eocene, creating the Apenninic orogenic wedge and inverting the vergence of subduction from south- to north-directed.
\end{abstract}

Keywords: subduction; obduction; Alps; plate tectonics; Briançonnais; Tethys

*Corresponding author. E-mail: gerard.stampfli@igp.unil.ch

0040-1951

PII: S $0040-1951(98) 00142-5$ 


\section{Introduction}

Subduction and obduction processes in the western Alps can be approached through different methods (i.e. stratigraphic and sedimentologic analyses, structural analyses and dating of metamorphism, etc. ...) but only a multidisciplinary effort can build enough constraints around a still debated subject. In our approach we used data from our own field work and also a vast amount of published data. These data sets have been analysed from a structural, petrological and sedimentological point of view. Structural models were constrained at depth by deep seismic data and lithospheric cross-sections (Stampfli, 1993; Marchant, 1993; Marchant and Stampfli, 1997b). Together with palaeontological and absolute age determinations, these data allowed the construction of subsidence curves and the elaboration of flexural models. These models were incorporated and constrained by palaeo-reconstructions made in real projection using the GMAP software (Torsvik and Smethurst, 1994).

Although there has been significant progress in the dating of metamorphism events in the last decade, it is in this field that the major controversies are found, mainly regarding the timing of high-pressure metamorphism affecting both the Piémont and Valais sutures. A review of the solid data regarding mainly the collision between the Briançonnais domain and the surrounding areas is therefore necessary to constrain controversial absolute ages. The exotic position of the Briançonnais terrane between the European Helvetic margin and the AustroalpineAdria margin is fundamental to determine the timing of closure of the oceanic Piémont area and the timing of the collision between the accretionary prism and the Helvetic margin. To do so we analysed evidence pertaining to the Briançonnais crustal nappes and covers from eastern Switzerland and the Briançonnais cover nappes found as exotic klippen in the Swiss and French Préalpes and compared them. The geodynamic evolution of these domains and surrounding areas involved in Tertiary collision allows us to determine what part of these terranes were subducted or obducted and at what time.

In a first section we present the plate tectonic framework of the Alpine-Mediterranean domain to place the Briançonnais in a global Jurassic and Cre- taceous context. Then we review first the eastern Swiss Briançonnais (mainly the Tambo and Suretta nappes), then the Swiss and French Subbriançonnais Préalpes Médianes in order to compare them and show their concomitant incorporation into the Tertiary accretionary prism as exotic terranes. We discuss the collision processes and try to develop more irrefutable arguments concerning subduction and obduction processes in the western Alps. Existing absolute ages are reviewed and placed in this context of ongoing deformation. In the discussion the HP-LT debated ages are reassessed together with the location and geometry of the subduction zone affecting the Alpine region.

\section{The geodynamic framework of the western Alps}

\subsection{The plate tectonics of the western Tethyan regions}

The reconstructions shown in Figs. 1 and 2 are based on a pre-break-up fit using palaeomagnetic pole data, Euler rotation poles, as well as magnetic anomalies from the Central Atlantic which we have combined to reconstruct a consistent model for the Alpine domain s.1. (Klitgord and Schouten, 1986; Srivastava and Tapscott, 1986; Rowley and Lottes, 1988; Srivastava et al., 1990; Srivastava and Verhoef, 1992).

This plate model takes into account the likelihood of a late Palaeozoic rifting and seafloor spreading of the eastern Mediterranean basin (Stampfli et al., 1991, 1998; Stampfli and Pillevuit, 1993). This opening was concomitant with the opening of the Neotethys and the drifting of the Cimmerian continents since the late-Early Permian. This implies also a late closure of the palaeo-Tethys (Late Permian to Triassic) on a Greek and Turkish transect of the Tethyan realm, accompanied by the opening of back-arc basins along the Eurasian margin (e.g. Meliata-Hallstatt and Vardar oceans; Stampfli et al., 1991; Stampfli, 1996; Stampfli and Marchant, 1997).

The opening and closing of the Meliata ocean affected the whole Alpine history. First it created a thermal subsidence starting in the Late Permian responsible for the general Triassic transgression in the Alpine domain (e.g. Fig. 3). Then its final 
closure in the Early Cretaceous affected the whole Austroalpine domain and can be seen as a major element in the onset of the closure of the Alpine Tethys itself (see Section 5).

\subsubsection{The Apulia-Adria problem}

It is possible to show that the Apulian plate s.l. (Italy) suffered relatively little rotation in regard to Africa since the Triassic (Channell, 1992, 1996; Channell et al., 1992; Channell and Doglioni, 1994). However, when rotating the Italian Peninsula backward using data from magnetic lineation in the Atlantic, its pre-break-up position is clearly superposed on the Iberian plate. This leaves open the question of an Apulian plate being an African promontory responsible for the Alpine collision. Also, the continuity between the active subduction zone under Greece and the outer Dinarides (Wortel and Spakman, 1992; de Jonge et al., 1994) shows that there is a possible plate limit between Apulia and the autochthonous units of Greece (Fig. 6).

Together with major problems concerning the reassembling of microplates in a pre-break-up position (Fig. 1), this led us to consider that the Apulian plate s.l. is most likely cut into two pieces, an Apulian plate s.str. to the south and an Adriatic plate s.str. to the north. Both pieces were joined together during the Late Permian or Early Triassic, but further lateral displacement between both microplates is likely. The Apulian plate was certainly attached to the African plate until the Early Cretaceous, then it started a lateral displacement to reach its final position in the Miocene as a separate entity (Fig. 2). This implies the opening of a Late Cretaceous ocean just north of the former east Mediterranean ocean, an ocean represented by the Antalya and Lycian ophiolitic nappes (Stampfli et al., 1998).

The Apulian plate can therefore be considered as an exotic or rather a displaced terrane like most large tectonic units from the former southern margin of the Alpine Tethys: the Austroalpine, Carpathians and Tisza composite terranes (Figs. 1 and 2). Unlike Apulia, still rooted in the lithosphere, these composite terranes were decoupled at upper crustal levels and incorporated into the accretionary prism, their lithospheric roots were subducted. Their composite nature comes from the fact that they record the closure not only of the Alpine Tethys ocean but also of older oceanic domains such as the Meliata and Vardar oceans (Channell and Kozur, 1997).

\subsubsection{The Alpine Tethys rifting}

Late Triassic ages obtained from shear zones in the southern Alps (Schmid et al., 1987; Zingg et al., 1990; Hunziker et al., 1992) and field evidence (e.g. Froitzheim and Manatschal, 1996), indicate important transtensive events which eventually led to the opening of the central Atlantic/Alpine Tethys ocean and the break-up of Pangaea. Areas affected by Permo-Triassic rifting became subsiding rim basins of the Jurassic Alpine Tethys (Fig. 1). The Jurassic rifting cut in between these zones of thinned and already cold lithosphere.

Subsidence patterns of the marginal areas of the Alpine Tethys (Loup, 1992; Borel, 1995, 1998; Mosar et al., 1996), together with stratigraphic and sedimentological data allow us to place the onset of the final rifting in the Sinemurian (Figs. 3 and 4), followed by a widespread thermal uplift phase in the Toarcian (Favre and Stampfli, 1992; Mosar et al., 1996) and followed by seafloor spreading starting in the early-Middle Jurassic (e.g. Bill et al., 1997). In the North Atlantic ocean, spreading can be placed in the early to middle Toarcian (Steiner et al., 1998). A diachronous opening of the North Atlantic-Alpine Tethys system with a rotation point near the Black Sea can be defined.

Thermal subsidence of the Alpine Tethys started in the Bajocian. The progradation of carbonate platforms toward the rift is hampered by the presence of rim basins on both sides of the Alpine Tethys: (1) to the north, the Helvetic-Dauphinois basin and its SW extension toward the Subbriançonnais rim basin, the Sardinia and the Subbetic rim basin; (2) to the south, the Lombardian rim basin representing an aborted arm of the Alpine Tethys active from the Late Triassic to Early Jurassic (e.g. Winterer and Bosellini, 1981; Bertotti et al., 1993).

Progradation did not succeed in filling these rim basins and the former rift shoulders of the Alpine Tethys (the Briançonnais and south Helvetic domains in the north and the Canavese and lower Austroalpine domains to the south) became drowned submarine ridges developing condensed sequences.

In the Subbriançonnais rim basin, a carbonate platform developed in Middle and Late Jurassic time. 

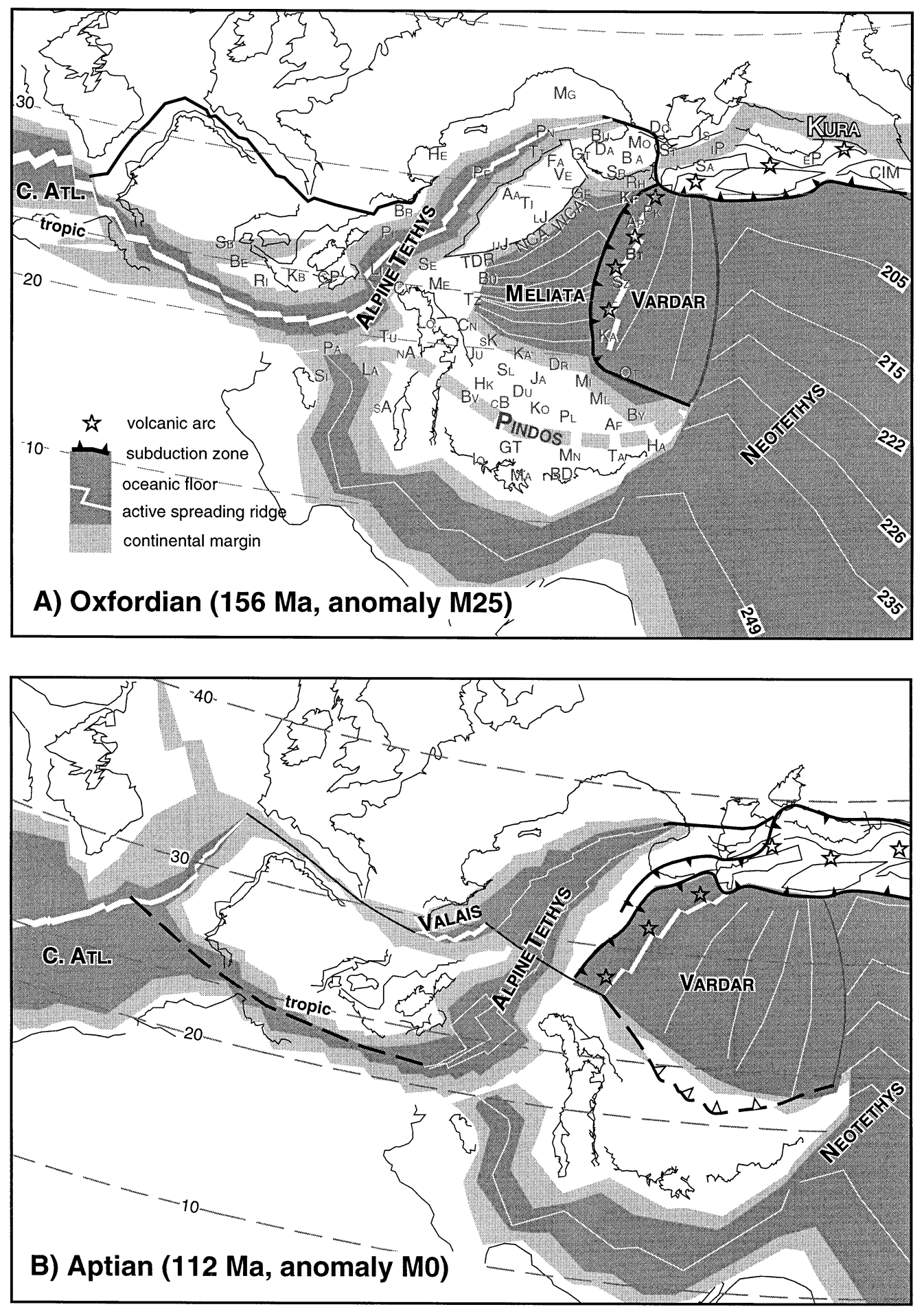
This platform, centred around the rift shoulder, prograded mainly towards the rim basin (i.e. towards the northwest, away from the oceanic realm) and is a characteristic feature of the Subbriançonnais domain (e.g. Septfontaine, 1983; Mosar et al., 1996).

\subsubsection{The Valais ocean}

In a model where the Briançonnais domain is attached to the Iberian plate (Frisch, 1979; Stampfli, 1993; Stampfli and Marchant, 1997), it can be determined that the opening of the Valais rift between the Briançonnais and southern France started in the Late Jurassic when Iberia separated from Newfoundland. In that area, the minimal Late Jurassic (160 Ma) to M0 (112 Ma; Srivastava et al., 1990; Sibuet and Colette, 1991) syn-rift opening would be $200 \mathrm{~km}$ according to the reconstruction of Malod and Mauffret (1990) or $350 \mathrm{~km}$ using that of Sibuet and Colette (1991). Discrepancies stem from the former pre-rift situation of Iberia with regard to Newfoundland. The data of Srivastava et al. (1990) and of Srivastava and Verhoef (1992) allow these differences to be narrowed down and their proposal was applied to our model. Similarly, a continental separation on the order of 200 to $250 \mathrm{~km}$ can be calculated for the Red Sea before the onset of seafloor spreading.

The Valais rift was roughly parallel to the Atlantic rift between Iberia and Newfoundland (Fig. 1) and opened at the same time and by the same amount. The oldest magnetic anomaly in this part of the Atlantic is M0 (Aptian). However seafloor spreading is inevitably slightly older than the first clear magnetic lineation (for the central Atlantic the discrepancy is on the order of 10 to $15 \mathrm{Ma}$; Favre and Stampfli, 1992; Steiner et al., 1998).

The Bay of Biscay rifting took place during the rotation of Iberia (after the Valanginian from palaeomagnetic data, Moreau et al., 1992; see also Olivet, 1996). Seafloor spreading there is younger than in the Atlantic between Iberia and America (M0, 112 Ma) and stopped in the Campanian (A33, 83-71 $\mathrm{Ma})$. In the Pyrenean region, the thermal event linked to the emplacement of basic material at depth started around $115 \mathrm{Ma}$ and lasted until $80 \mathrm{Ma}$ (Montigny et al., 1986).

Different subsidence behaviour (see Borel, 1998 for a review) can be noticed between the basins related to the opening of the Atlantic between Newfoundland and Iberia (Jeanne d'Arc, Lusitanian, Provence, Valais, S Helvetic) and the basins related to the rotation of Iberia (Biscay, Pyrenees, Aquitaine, Cantabric, western Paris basin). For the latter group, thermal subsidence is active in the Late Cretaceous where the Cenomanian is largely transgressive on the former rift shoulders (e.g. in the Pyrenees, Peybernès, 1976; Peybernès and Souquet, 1984; Simo, 1986; in Normandy, Mégnien, 1980), which implies a seafloor spreading older than the Cenomanian. For the first group, as shown by the subsidence curve established for the Préalpes Médianes (Fig. 3), the onset of thermal subsidence can be placed in the Valanginian (132-137 Ma, Gradstein et al., 1995; 122-130 Ma, Odin and Odin, 1990). Actually a major change of sedimentation in the Subbriançonnais domain is found at the top of the Calcaires Plaquetés (Python-Dupasquier, 1990) and

Fig. 1. (A) Early-Late Jurassic reconstruction (Oxfordian, $156 \mathrm{Ma}$, magnetic anomaly M25) of the Mediterranean-western Tethys domain. Europe fixed in present-day position, orthogonal projection centred at $30^{\circ} \mathrm{N}, 0^{\circ} \mathrm{E}$. (B) Early Cretaceous reconstruction (middle Aptian, $112 \mathrm{Ma}$; magnetic anomaly M0). $A A=$ Austroalpine east; $A F=$ Afyon; $A P=\mathrm{S}$ Apuseni (arc, back-arc); $B A=\mathrm{Balkhanides;} B T$ $=$ Bator (back-arc); $B D=$ Beydaghlari; $B E=$ Betic; $B Y=$ Beysehir; $B R=$ Briançonnais; $B U=$ Bucovinian; $B \ddot{U}=$ Bükk, Fatric; $B V=$ Budva; $C B=$ central Bosnia; $C I M=$ Cimmerian blocks; $C N=$ Carnic; $C P=$ Calabria, Peloritani; $C V=$ Canavese; $D A=$ Dacides; $D O$ $=$ Dobrogea $D R=$ Drina-Ivanjica; $D U=$ Durmitor; $E P=$ east Pontides; $F A=$ Fatric; $G E=$ Gemeric; $G T=$ Gavrovo-Tripolitza; $G T$ $=$ Getic; $H A=$ Hadim, East Taurus; $H E=$ Helvetic rim basin; $H K=$ high karst; $I O=$ Ionian; $I S=$ Istanbul; $J A=\mathrm{Jadar} ; J U=\mathrm{Julian}$ Alps; $K A=$ Kalnic; $K B=$ Kabylies; $K C=$ Kura south Caspian; $K F=$ Kotel flysch; $K O=$ Korab; $L A=$ Lagonegro; $L I=$ Ligurian; $L J$ $=$ lower Juvavic; $L O=$ Lombardian rim basin; $M A=$ Magura margin; $M A=$ Mani; $M E=$ Mesek west Tizia; $M I=$ Mirdita; $M L=$ Maliak; $M N=$ Menderes; $M O=$ Moesia; $N A=$ north Apenninic; $N C A=$ North Calcareous Alps; $O T=$ Othrys-Evvia ophiolites; $P A=$ Panormides; $P E=$ Penninic; $P I=$ Piemontese; $P K=$ Paikon (intra oceanic arc); $P L=$ Pelagonian; $P N=$ Pienniny; $R H=$ proto-Rhodope (prism); $R I=$ Rif; $S a=$ Sakarya; $S A=$ south Apennines; $S B=$ Subbetic rim basin; $S E=$ Sesia, Austroalpine west; $S I=$ Sicanian; $S K$ $=$ south Karawanken; $S L=$ Slavonia; $S R=$ Srednogorie; $S T=$ Strandja; $S Z=$ Szarvasko $(\operatorname{arc}$, back-arc); $T A=$ west Taurus; $T D R=$ Trans-Danubian range; $T I=$ Tirolic, Bavaric; $T T=$ Tatric; $T u=$ Tuscan nappes; $T Z=$ Apuseni east Tizia; $U J=$ upper Juvavic; $V E=$ Veporic; $W C A=$ western Carpathian. 

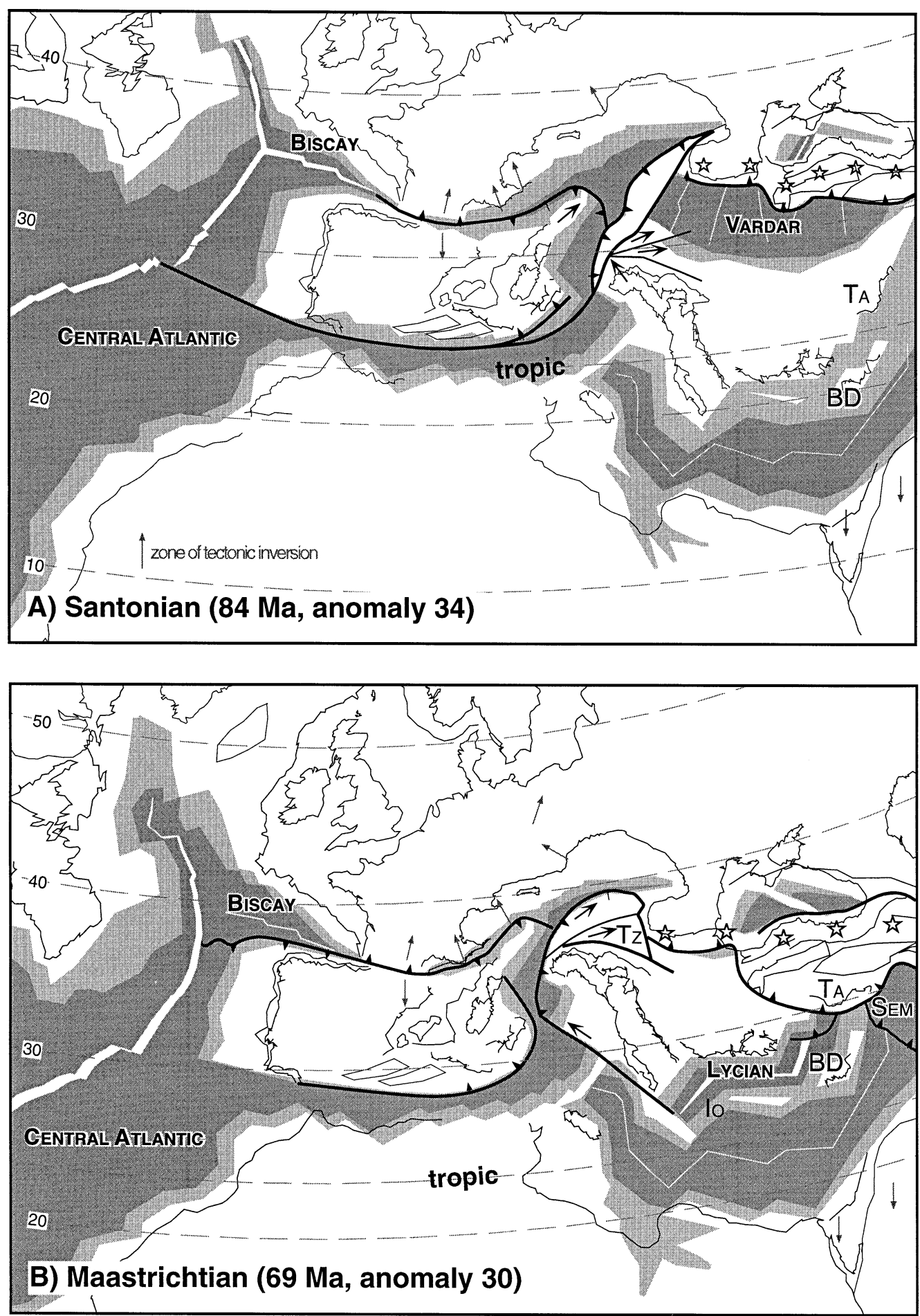

Fig. 2. Late Cretaceous reconstructions. (A) Santonian/Campanian boundary (84 Ma; magnetic anomaly 33). (B) Maastrichtian (69 Ma; magnetic anomaly 30). See Fig. 1 for legend. 


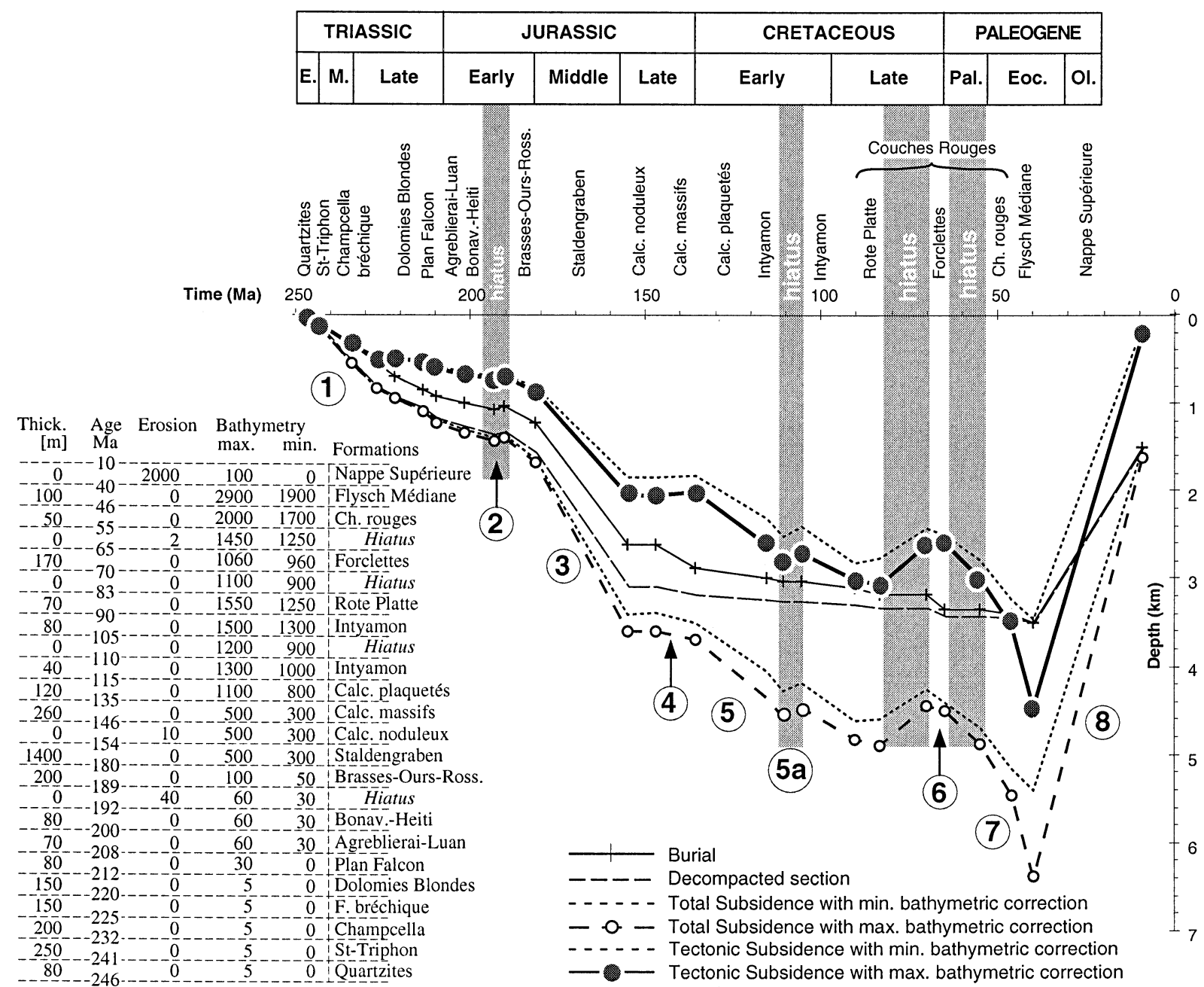

Fig. 3. Synthetic subsidence curves for the Préalpes Médianes, modified from Mosar et al. (1996) and Borel (1998). The subsidence program used to derived the curves is from R. Schegg. Timescale from Gradstein et al. (1995). $l=$ thermal subsidence of the HallstattMeliata rift; $2=$ Alpine Tethys rift thermal expansion; $3=$ Alpine Tethys thermal subsidence; $4=$ Valais rift thermal expansion; $5=$ Valais thermal subsidence; $5 a=$ onset of closure of the Valais ocean; $6=$ flexural bulge and Cretaceous Valais subduction uplift; $7=$ flexural trough; $8=$ obduction.

can be dated as Barremian (121-127 Ma, timescale of Gradstein et al., 1995; 114-116 Ma, timescale of Odin and Odin, 1990). Therefore, spreading in the Valais ocean could have lasted from the BarremoAptian to the Albo-Cenomanian, as the rotation of Iberia and seafloor spreading in the Bay of Biscay since the Albian implies a concomitant closure of the Valais ocean. This closure generated a hiatus in the Subbriançonnais basin (event 5a in Fig. 3) and westward, in the French Subbriançonnais, important deep marine re-sedimented material is found in the Albian and early Cenomanian deposits (Kerckhove, 1969; Kerckhove and Lereus, 1987). A total opening of $200 \mathrm{~km}$ during the rifting phase and more or less the same amount during spreading can be envisaged for the Valais ocean.

Both Valais margins disappeared into the lower Penninic suture zone and only the surrounding areas (rim basins, rift shoulders) can give clues about their evolution. The Préalpes Médianes Lower Cretaceous 


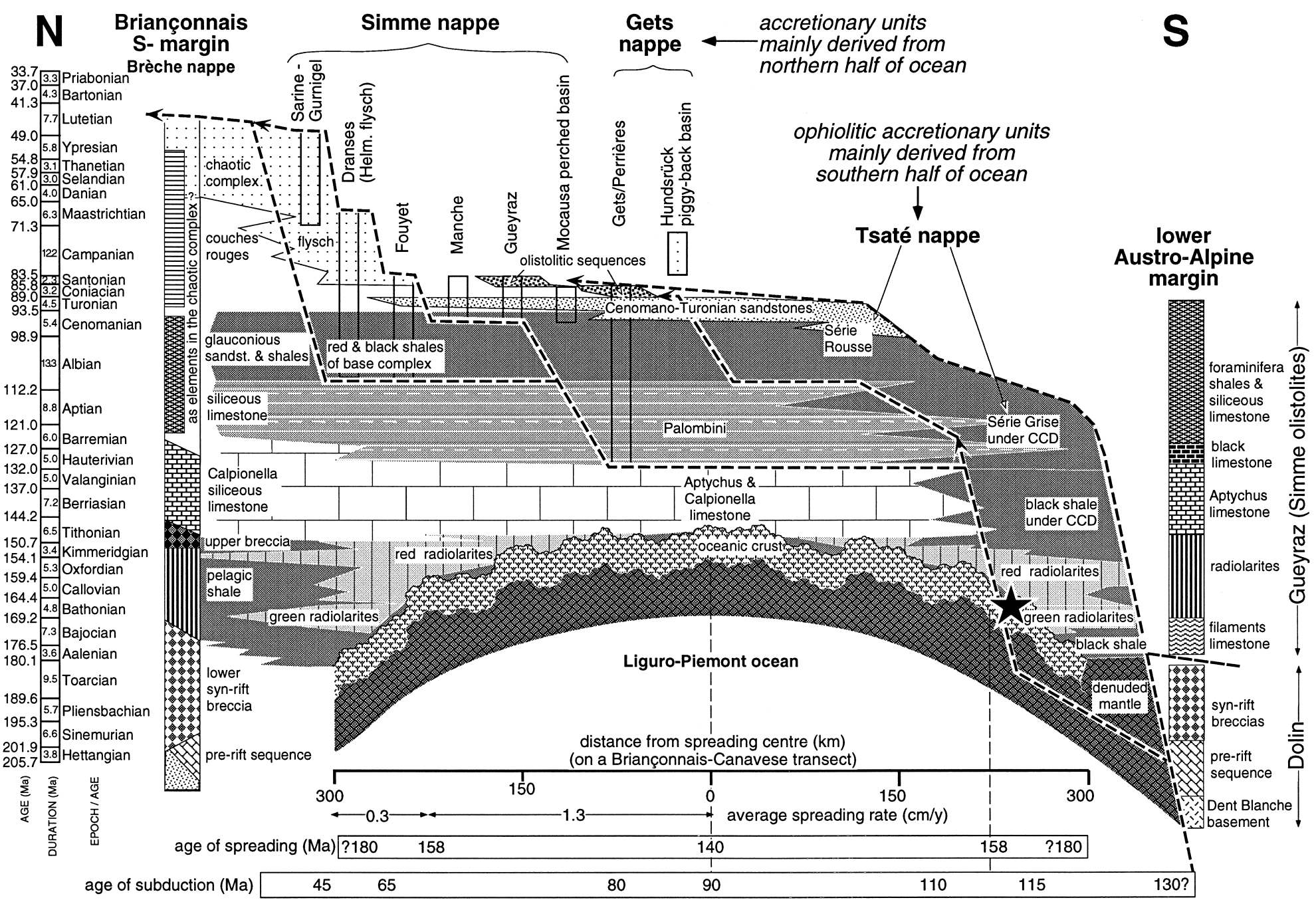

Fig. 4. Stratigraphy and origin of the oceanic series found in the accretionary sequences of the western Swiss Alps. Timescale from Gradstein et al. (1995). It can be seen that the Cretaceous accretionary units found nowadays in the Préalpes (Nappes Supérieures) are mainly derived from the northern half of the Liguro-Piémont ocean and the Tsaté accretionary units from the southern half. The star symbol represents recently dated gabbros from the Gets nappe (Bill et al., 1997). 
sequence, representing the southern shoulder area, is condensed (Python-Dupasquier, 1990) but stayed in relatively deep water conditions throughout the Cretaceous period. This region was formerly part of the Liguro-Piémont ocean Jurassic passive margin and was brought down to depth, close to the CCD, by thermal subsidence during the late-Middle Jurassic (Borel, 1995, 1998). The Early Cretaceous Valais tectonic/thermal uplift was therefore insufficient to cause it to emerge.

An oceanic connection with the Atlantic existed through the Valais/Pyrenean system. The similitude of facies between the Rheno-Danubian flysch and the Valais sequence from the Albian to Late Cretaceous (Stampfli, 1993, and references therein), and the continuity of deep water clastic facies in these two domains allows them to be assigned to the same position with regard to the European margin. The presence of contourites and strong and changing current directions along the basin (Hesse, 1974) suggest a connection with the major oceanic domains. In the Ligurian domain such turbiditic deposits are absent, the Albo-Cenomanian formation being dominated by anoxic black-shale deposits (Fig. 4).

\subsubsection{Valais subduction}

The rotation of Iberia since the Turono-Senonian implies the closure of the Valais ocean and Provence basin since that time too (Fig. 2). Subduction-related sediments from the Valais ocean have not yet been dated (see below), but in Provence, the Ciotat conglomerate records major clastic input coming from the southeast at that time (Philip et al., 1987). First stages of inversion in the French external Alps (Devoluy region) are also dated as Turono-Senonian (Huyghes and Mugnier, 1995). A flexural bulge developed in Provence during the Late Cretaceous, the flexural basin became lacustrine during the Maastrichtian (Debrand-Passard and Courbouleix, 1984). In the external Swiss Alps the Late Cretaceous Niesen conglomerates (Campanian-Maastrichtian; Ackermann, 1986) could be related to the flexure of the Helvetic margin (Fig. 14), although an origin from a major inversion of the northern Valais margin is more likely. The Niesen conglomeratic input seems to stop in the Maastrichtian (migration of the flexural bulge), it is followed by the Chesselbach flysch whose age reaches the late Lutetian
(Ackermann, 1986), Paleocene sediments seem to be absent, but Paleocene fauna is reworked in the flysch. Large conglomeratic influxes started again in the external domain during the Lutetian with the deposition of the Meilleret flysch (Homewood, 1974). The continuity of inversion-related deposits from the Campanian to Lutetian in the external Valais/Ultrahelvetic domain precludes any final closure of this domain before that time (40 Ma).

Subduction of the buoyant young Valais ocean crust certainly increased the intra-plate stress within the European margin, and could be responsible for the widespread inversion phase affecting large areas of the European plate already during the Late Cretaceous (Ziegler, 1990; Ziegler et al., 1995).

\subsection{Exotic terranes in the Alps}

\subsubsection{The Briançonnais terrane}

The separation of the Iberian plate from North America in the Late Jurassic implies a separation of the Iberian plate from Europe too. This separation, as we have seen, is brought about by the Pyrenean pull-apart rift system extending eastward into the Valais or North Penninic suture zone (Frisch, 1979; Stampfli, 1993).

The Briançonnais domain (Figs. 1 and 2) was attached to Corsica/Sardinia and therefore to the Iberian plate (Stampfli, 1993). Its former position was thus more to the (present) southeast than usually supposed (e.g. Dercourt et al., 1993) and the Valais trough was never connected to the Vocontian trough (as proposed by Dercourt et al., 1985 and by Yilmaz et al., 1996). The most internal south Helvetic domains (Ultrahelvetic), the lower Penninic Lepontine nappes and external Valais zone (i.e. zone Submédiane and the Bündnerschiefer) are therefore considered as former elements of the northern Alpine Tethys oceanic margin trapped by the eastward displacement of the Briançonnais terrane together with the Iberian plate. This displacement induced a duplication of this northern margin in the present-day Alpine orogen. The Valais ocean (sometimes referred to as the North Penninic ocean) is therefore a composite oceanic strip comprising a small segment of the Early Jurassic margin to the north (Fig. 1), represented by the Bündnerschiefer and elements of the Zone Submédiane (see below). 


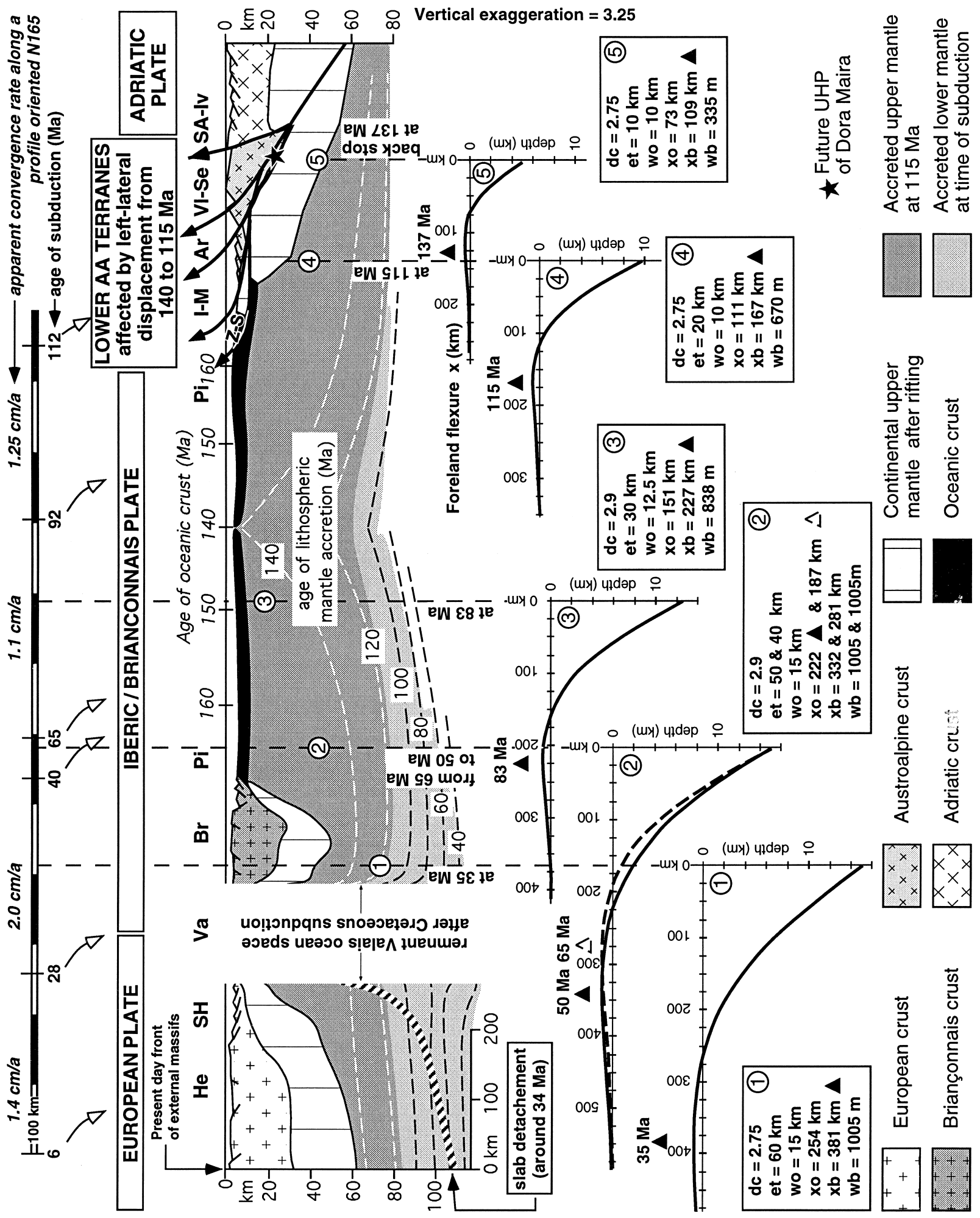




\subsubsection{The Austroalpine terranes}

The drifting of Iberia in the Early Cretaceous as well as the final closing of the remnant Meliata domain induced the subduction of the Liguro-Piémont part of the Alpine Tethys ocean in the Late Cretaceous. This is marked by HP-LT metamorphism (Hunziker et al., 1992) of elements pertaining to the toe of the Austroalpine margin (Fig. 5) and of the accretionary prism s.str. (Tsaté nappe, Fig. 4; Marthaler and Stampfli, 1989; Stampfli and Marthaler, 1990; Deville et al., 1992; Fudral, 1996). This means that most of the southern margin of the Alpine Tethys is made of exotic terranes, some of them (most of the Austroalpine?) possibly derived from the Meliata prism. In the western Alps, some of these were obducted (Dent-Blanche, Arolla-Valpelline) and displaced westward along the margin, others were only partially subducted (Sesia) and formed the back stop of the Alpine Tethys accretionary prism. Other elements were subducted and underplated at different depths and suffered important eclogitic metamorphism (internal massifs: Monte Rosa, Grand Paradis, Dora Maira, see discussion below). The westward displacement of the Austroalpine elements (Frank, 1987; Ratschbacher and Neubauer, 1989; Trümpy, 1992; Froitzheim et al., 1994) is in part related to tectonic escape movements within the Meliata accretionary prism (Froitzheim et al., 1997), although it is mainly due to an eastward-directed relative movement of Apulia, as seen in Fig. 2, following the onset of subduction of the Vardar ocean under the Rhodope.

\subsubsection{The Alboran terranes}

The Alboran plate (Rif, internal Betic, Kabylies, Peloritan, Calabria, Sardinia-Corsica microplates; Wildi, 1983) formed the southern margin of the Iberian plate (Fig. 1). This margin was affected by deformation processes from the Early Cretaceous onwards (Puga et al., 1995). Resedimentation of the Dorsale Calcaire (former rift shoulder of the southern margin of the Iberian plate) in the Rif flysch basin starts in Cenomanian time, grading into major olistostrome deposits in the Maastrichtian (Gübeli, 1982; Thurow, 1987) which we relate to the major transform linking the Atlantic and the Vardar regions, cutting in between Adria and the Austroalpine domain (Fig. 2). In Eocene-Oligocene times the Alboran (Iberian) plate locally collided with North Africa, which was accompanied by major terrane displacements and the late Tertiary opening of the Algero-Provençal and Tyrrhenian oceans, liberating the Alboran blocks from their Iberian motherland (Fig. 6). Here too, lateral displacements generated duplication of palaeogeographic elements, creating pseudo-oceanic sutures. We propose a displacement toward the southwest of the internal Betic domains (together with the Rif) subsequently incorporated into the Betic orogen as a terrane.

The Iberian margin is considered an active margin developing back-arc spreading at least since Eocene time, whilst the African margin is considered a passive margin. Terrane displacement was related to the slab roll-back of the Alpine Tethys and the local detachment of this slab.

\section{The Briançonnais terrane in eastern Switzerland}

\subsection{Geological setting}

\subsubsection{Introduction}

We shall now review in detail the geodynamic evolution of the Briançonnais terrane. Its exotic position is fundamental for determining the timing of closure of the oceanic Piémont area and the timing of the collisional events. We start first with the Bri-

Fig. 5. Evolution of the structural bulge during the subduction of the European-Iberian-Briançonnais plates. As the slab subducts the lithosphere becomes thicker, the dark grey part of the lithosphere corresponds to the thickness at the time of the reconstruction for the Alpine Tethys segment, the light grey to final thickness before the slab detachment around 35 Ma. It can be seen that the Briançonnais domain entered the flexural bulge around $90 \mathrm{Ma}$ and was in the subduction trough around 50 to $45 \mathrm{Ma}$. Ar = Arosa (Dent-Blanche); $B r=$ Briançonnais; $H e=$ Helvetic; $I-M=$ internal massifs (Monte Rosa; Grand Paradis); $P i=$ Piémont ocean; $S A-I v=$ southern Alps-Ivrea; $S H=$ South Helvetic; $V a=$ Valais ocean; $V l-S e=$ Valpelline (Dent-Blanche)-Sesia; Z-S = Zermatt-Saas ophiolite. Flexural model from M. Burkhard (Neuchâtel): $d c=$ density of crust; $e t=$ elastic thickness; $w o=$ maximum depression; $x o=$ zero elevation position of bulge; $x b=$ maximum elevation position of bulge; $w b=$ height of bulge. 


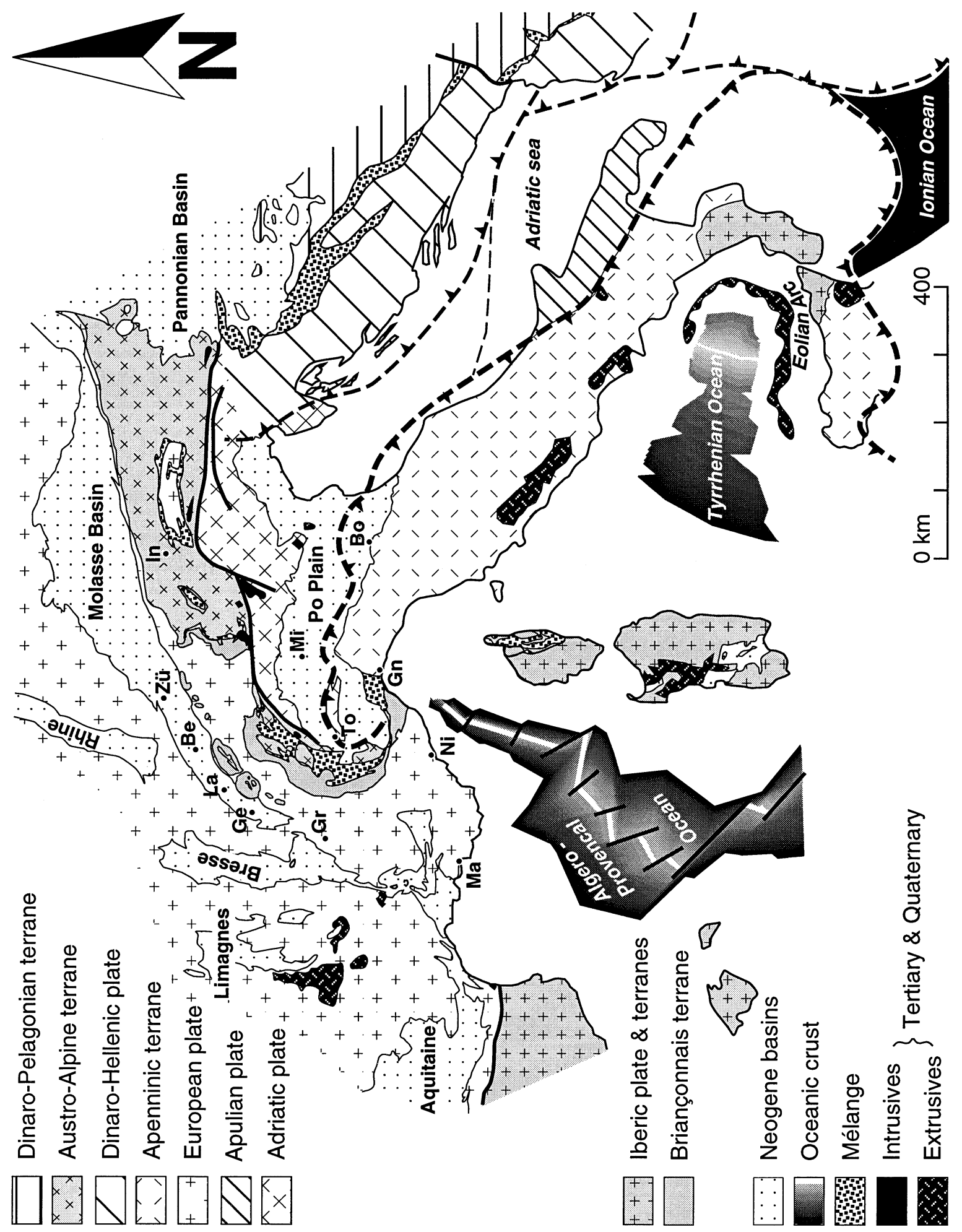


ançonnais basement from eastern Switzerland where recent studies allow a precise determination of the structural and metamorphic history.

The central Swiss Alps can be divided into the three following structural domains: (1) an external part, the Helvetic; (2) an internal part, the Penninic zone; and (3) the South Alpine units (e.g. Coward and Dietrich, 1989). The Penninic zone corresponds to the internal parts of the Alpine mountain belt. This area is constituted of imbricate stacks of sediment covers and basement slices. Deformation of these domains is related first to oceanic subduction processes starting in the Early Cretaceous, followed by incorporation of exotic terranes and finally collision of the two continents in the Tertiary. This implies several phases of deformation and systematic refolding of former structures.

Early cartographic and petrological work (Staub, 1916, 1924; Wilhelm, 1933; Grünenfelder, 1956; Gansser, 1937; Zurflüh, 1961; Blanc, 1965; Strohbach, 1965; Weber, 1966; Streiff et al., 1976), and recent detailed mapping and stratigraphic observations (Suretta nappe, Milnes and Schmutz, 1978; Schams nappes, Schmid et al., 1990; Schreurs, 1993; Tambo nappe, Baudin et al., 1993; Mayerat, 1994; Suretta cover, Baudin et al., 1995) allow the structural units in this part of the Alps (Fig. 7) to be clearly defined.

The Suretta and Tambo nappes belong to the eastern part of the Briançonnais terranes, together with their cover, the Schams and Starlera nappes in the north (Fig. 7). A new detailed tectonic framework for the frontal part of the Suretta nappe and of the Tambo nappe is described in Marquer et al. (1996) and in Baudin et al. (1993), respectively. One of the main results of these studies is the strong heterogeneous deformation undergone by the basement rocks during the Tertiary tectonics, leading to lenses of preserved material surrounded by mylonite zones at all scales. This peculiar geometry makes a precise deformation-metamorphism analysis along zones with a strain gradient (such as mylonite zones) and in areas of weak Alpine deformation possible (Marquer et al., 1994, 1996). The second main result is the description of a new unit, the Starlera nappe, lying on the reduced autochthonous cover of Tambo and Suretta (Baudin et al., 1995) (Fig. 7).

The Tambo and Suretta nappes form a thin crystalline sliver, each about $3.5 \mathrm{~km}$ thick and covered by a reduced autochthonous sedimentary cover. They are mainly composed of old crystalline basement and small occurrences of Early Permian granites (Roffna and Truzzo granites). These nappes are bounded by different Permo-Mesozoic covers (Gansser, 1937). (1) The Misox zone, between Tambo and Adula, which is the southern extremity of the North Penninic Bündnerschiefer and flysch domain (Steinmann, 1994a) and does not exceed $800 \mathrm{~m}$ in thickness. This zone consists mainly of calcareous schists with some extremely stretched lenses of gneisses (Gadriol gneiss) and basic rocks (MORB of Valais and/or Piémont origin; Dürr et al., 1993; Steinmann, 1994a,b). (2) The Splügen zone, between Tambo and Suretta and the Avers and Schams nappes at the top of Suretta. The Splügen zone shows important thickness variations.

\subsubsection{Polycyclic basements}

The polycyclic basements are essentially composed of metapelites and metagreywackes (paragneiss and micaschists) including some lenses of mafic rocks (amphibolites) with local migmatites (Wilhelm, 1921; Staub, 1924; Gansser, 1937; Grünenfelder, 1956; Schaerer, 1974).

The basement rocks of Suretta are intruded by pre-Alpine magmatic bodies (Fig. 7), and an Early Permian subvolcanic intrusion, the Roffna granite, in the frontal part (Marquer et al., 1996). The Roffna porphyry has a high-level intrusive and volcanic origin (Grünenfelder, 1956; Milnes and Schmutz, 1978) and forms the frontal part of the Suretta nappe. Until now, its age has been considered to be 350 $\mathrm{Ma}\left({ }^{207} \mathrm{~Pb} /{ }^{206} \mathrm{~Pb}\right.$; Hanson et al., 1969) but new age determination (in progress) and the similarity of most of these volcaniclastic facies with those of the Permo-Triassic cover, directly overlain by Triassic

Fig. 6. Present-day plate tectonic setting and distribution of major tectonic units in the Alpine and western Mediterranean areas. $B e=$ Bern; $B o=$ Bologna; $G e=$ Geneva; $G n=$ Genova; $G r=$ Grenoble; $I n=$ Innsbruck; $L a=$ Lausanne; $M a=$ Marseilles; $M i=$ Milano; $N i=$ Nice; $T o=$ Torino; $Z \ddot{u}=$ Zürich. (Modified from Stampfli and Marchant, 1997.) 


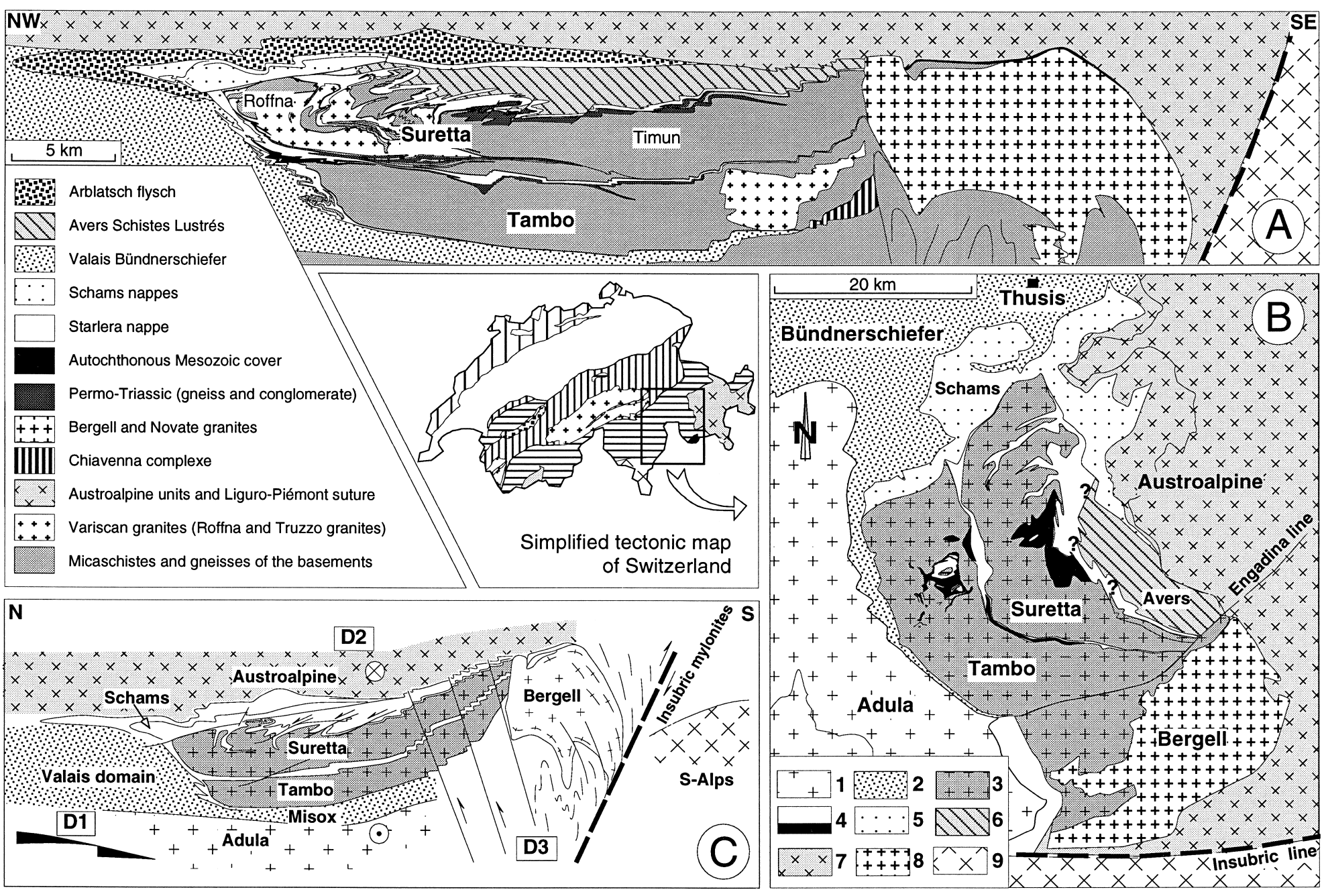

Fig. 7. (A) Cross-section of the internal eastern Swiss Alps showing the structure of the Suretta and Tambo Briançonnais nappes. (B) Simplified structural map of the internal eastern Swiss Alps. 1 = European units of the lower Penninic structural domain (Adula); $2=$ Bündnerschiefer of the Valais domain; $3=$ Briançonnais basement nappes: Tambo and Suretta north of Engadina line, Chiavenna, Gruf, Belinzona-Dascio south of the line; $4=$ Briançonnais covers, allochthon: Starlera (white); autochthon (black); $5=$ Schams nappe; $6=$ Avers Schistes lustrés (Piémont oceanic accretionary units); $7=$ Austroalpine domain; $8=$ Bergell granite; $9=$ south Alpine domain. (C) Synthetic tectonic scheme of cross-section (A). 
carbonate, indicate a Permian age. The intrusive relationships between the foliated basement and the Roffna granite show that the basement rocks present a strong deformation, trending NNE-SSW, and a high-grade metamorphism inprint older than Early Permian. Lenses of mafic rocks are found in the Suretta basement (Timun complex; Zurflüh, 1961; Blanc, 1965) and new metamorphism-deformation studies allow two distinct subduction events for this basement to be defined: one pre-Alpine HP-HT and the second Alpine HP-LT (Biino et al., 1997).

The Tambo basement consists mainly of polycyclic rocks which are intruded in the south by the Truzzo granite. Much of this basement is characterised by strong pre-Alpine deformation. In the northern part of the nappe, alignment of lenses of mafic and ultramafic rocks are especially well developed. These amphibolites with a few preserved pyroxene-garnet assemblages (pyroxenites or eclogites) testify to a pre-Alpine HP-HT metamorphism (Biino et al., 1997). In other parts of the nappe, these mafic rocks have suffered a complete retrograde metamorphism which produced prasinites or ovardites. The monocyclic basement in the Tambo nappe is represented by the Truzzo granite, wellexposed in the southern part of the nappe (Blanc, 1965; Weber, 1966; Gulson, 1973; Marquer, 1991). This granitic complex is $293 \pm 14 \mathrm{Ma}$ old $(\mathrm{Rb} / \mathrm{Sr}$ whole rock dating; Gulson, 1973) and has suffered Alpine deformation only. It appears as an originally isotropic and homogeneous body of porphyritic granite (with centimetric K-feldspar porphyroclasts), crossed by many Alpine shear zones (Marquer, 1991). The top of the granite is generally overlain by polycyclic rocks except in the southeastern part of the area, where it is directly covered by the Permo-Triassic unit (see below).

\subsubsection{Cover units}

Autochthonous cover. The chemical composition and textures of the Roffna granite are close to those of rhyolitic-granitic rocks and they are associated with volcanic effusives (metatuffs) unconformably overlying the basement of both the Tambo and the Suretta nappes. This monocyclic Permian volcaniclastic cover progressively grades into conglomerates, subsequently metamorphosed into chloritoalbitic gneiss. Our recent field work has revealed

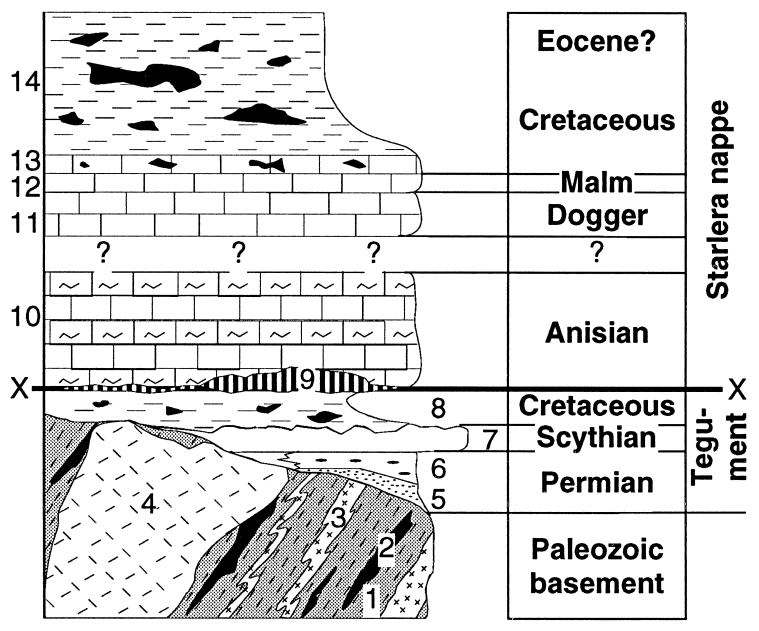

Fig. 8. Synthetic lithological section of the Suretta nappe. 1 $=$ micaschist and paragneiss; $2=$ amphibolite, prasinite; $3=$ orthogneiss; $4=$ Roffna gneiss; $5=$ albitic micaschists; $6=$ conglomeratic micaschists; $7=$ quartzites; $8=$ lower polygenic breccias with calcschist matrix; $9=$ Cornieules; $10=$ dolomites and limestones; $11=$ dark fetid limestones; $12=$ white marbles; $13=$ upper polygenic breccias with white marble matrix; $14=$ upper polygenic breccias with white calcschist matrix. Modified after Baudin et al. (1995).

that monocyclic Permo-Triassic rocks are more abundant in the Tambo and Suretta nappes than previously recognised (Baudin et al., 1991). They generally overlie the basement, but can also be found as thin wedges pinched between slabs of crystalline rocks at the front or in the roof of the nappe, and also at the base of the overlying Suretta unit (Fig. 8). The age attribution of the Permo-Triassic cover is based on its stratigraphic position between old basement and Mesozoic carbonate series, and its facies, which is similar to that of the Briançonnais zone (Staub, 1958a). Conglomerates at the bottom of the stratigraphic pile show lithological similarities with the classic Verrucano facies and pass progressively into more quartzitic formations. In places, the series seems to begin with an augengneiss a few metres thick and generally shows strong volcaniclastic tendencies with gneiss-like rocks rich in $\mathrm{K}$ - and Na-feldspars. One can observe a clear facies convergence between the latter rocks and the Roffna porphyry.

This Permo-Triassic sequence is followed upwards by pure quartzite present only on the Suretta nappe, probably Scythian in age. On Tambo and Suretta, a strongly reduced carbonate series, with 
polygenic breccia, lying unconformably on the older sediment or directly on the basement exhibits a Briançonnais-type stratigraphy (Baudin et al., 1995). For a long time, the carbonate Mesozoic cover of the Tambo nappe (Splügen zone) and the Suretta nappe were regarded by most previous authors (with the exception of Staub, 1958b) as only Triassic. Our recent field work has shown the presence of a complete cover in a normal position, systematically overlying the Permo-Triassic cover. It compares well with other areas of the Briançonnais (Barrhorn series, Sartori, 1990; and Vanoise cover, Jaillard, 1988) characterised roughly by the same stratigraphic sequence starting with Middle Triassic dolomite, followed by the Dogger or Malm breccias, Malm layered marbles and Cretaceous (up to Palaeogene?) phengite-rich marbles or calcareous schists and breccia. These facies are also found in the Schams nappe, located in front of Tambo/Suretta basement units (Schmid et al., 1990; Mayerat, 1994). The thickness of the Mesozoic Splügen zone varies from a few metres up to several hundred metres.

Allochthonous cover. The sedimentary rocks above the Suretta and Tambo nappes are regarded as a series which can be divided into a reduced autochthonous cover overlain by a more complete allochthonous cover, the Starlera nappe (Baudin et al., 1995). It must be pointed out that the Permo-Triassic and the carbonate series of the autochthonous cover are frequently separated by a cornieule layer which developed from Middle Triassic dolomites (and evaporites?) belonging to the Starlera nappe. The compilation of several sections, already described by Baudin et al. (1995), allows the stratigraphy of this nappe to be summarised from the bottom to the top as follows (Fig. 8).

Banded marbles and dolomites (Middle Triassic), dark stinky marbles sometimes with monogenic microbreccias (Dogger), massive ivory-white marbles (Malm) and a thick member of calcschists and breccias. These breccias are polygenic and contain clasts of basement, Triassic quartzites and dolomites as well as Jurassic carbonates. At the top of the Suretta nappe, the breccia grades upwards into a thick calcschist series, including large basement boulders and is therefore hardly distinguishable from the Avers Schistes Lustrés.
No age determinations were possible and the interpretation of the given ages has to be taken with caution. They are based on a facies comparison with the typical French Briançonnais series (Barféty et al., 1992). Alternatively to the hypothesis of an early syn-orogenic history for the 4th écaille described by Barféty et al. (1992), this series is interpreted here as a syn-rift sequence (Fig. 9).

\subsection{Tectonic evolution of the eastern Penninic Alps}

\subsubsection{Introduction}

The Alpine nappe pile was created in a subduction zone environment during the closure of the Piémont and Valais oceans. The Austroalpine nappes were thrust towards the west during the Late Cretaceous oceanic subduction phase (see review in Froitzheim et al., 1994), whereas the Penninic units were emplaced by thrusting towards the northwest in the early Tertiary (e.g. Schmid et al., 1996). The upper Penninic units represent an orogenic wedge, consisting of underplated basement and sedimentary slices detached during the oceanic closure (e.g. Marquer et al., 1994). During the early Tertiary the Misox zone was subducted below the Tambo and Suretta northern Briançonnais border. The overall structure of this area was already recognised by Milnes (1974), based on structural observations in the Suretta nappe. On a larger scale, the basement slices were thought to be a combination of thrusts and huge recumbent folds (Milnes, 1974; Milnes and Schmutz, 1978). Recent structural and seismic investigations in the eastern Swiss Alps showed that the nappe geometry appears to be related to thrust tectonics and postnappe refolding (Schmid et al., 1990; Pfiffner, 1990; Pfiffner et al., 1990b; Schreurs, 1993; Marquer et al., 1996). Recent investigations (Suretta nappe, Milnes and Schmutz, 1978; Marquer et al., 1996; Schams, Schmid et al., 1990; Schreurs, 1993; Tambo nappe, Baudin et al., 1993; Mayerat, 1994; Suretta cover, Baudin et al., 1995; Adula nappe, Heinrich, 1982; Löw, 1987; Meyre and Puschnig, 1993; NFP-20East, seismic lines, Pfiffner et al., 1988, 1990a; Frei et al., 1989; Schmid et al., 1990) and tectonic models (Merle et al., 1989; Schmid et al., 1990; Marquer et al., 1994; Merle, 1994) gave different scenarios of Tertiary tectonic evolution for this area. For the Suretta and Tambo nappes, the sequence of Alpine 


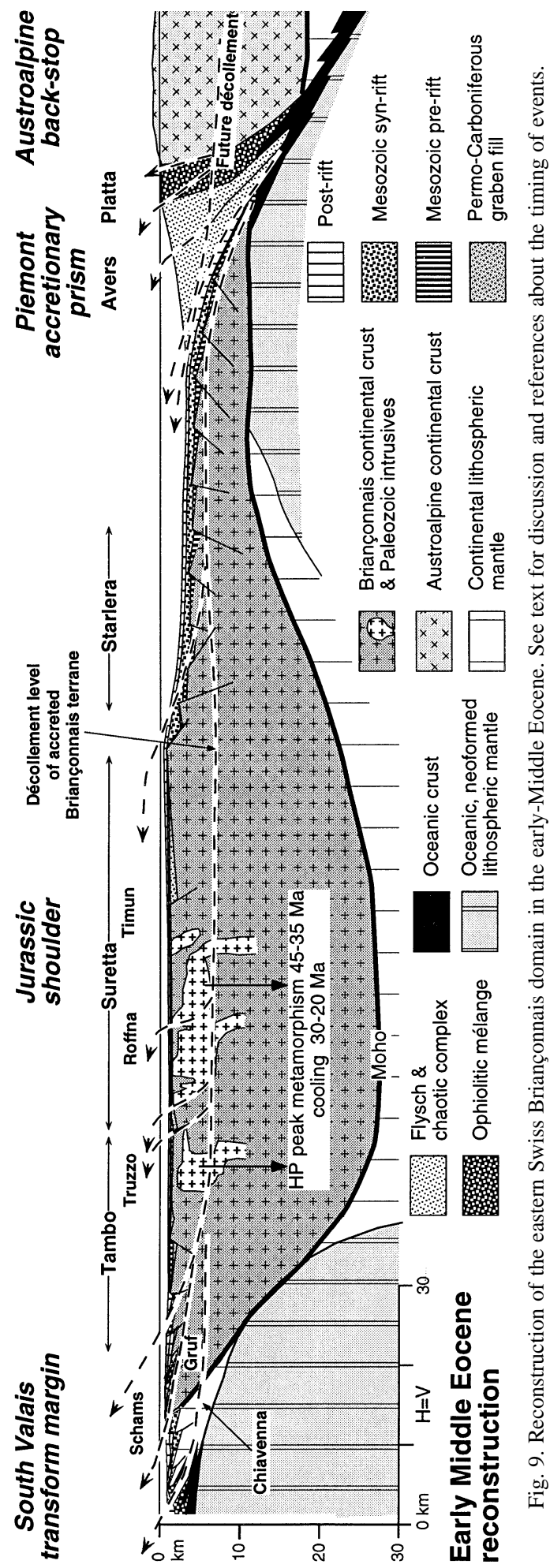

deformation events can be divided in four stages (D1 to D4) following the emplacement of the Starlera nappe (according to Baudin et al., 1993; Marquer et al., 1994, 1996). There is some disagreement in these models concerning the D2 deformation event and the associated overall kinematics (see discussion in Nievergelt et al., 1996).

\subsubsection{Thin-skin tectonics}

The Starlera nappe (Fig. 8), recently defined as an early cover décollement (Baudin et al., 1995), tectonically overlies either the reduced autochthonous cover or the basement of the Tambo and Suretta units. In the Splügen zone located between the Tambo and Suretta units, the Suretta nappe directly overlies the Starlera nappe. This early thin-skin tectonics is of importance because it constrains the palaeogeographic reconstructions as the following thrusts will develop an out of sequence geometry.

\subsubsection{Subduction of the Briançonnais terrane}

The stacking of the Adula, Tambo and Suretta nappes results from early Tertiary crustal stacking (Marquer et al., 1994). A narrow suture, the Misox zone, separates the south European margin (Adula nappe) from the Briançonnais Tambo and Suretta nappes. The Misox zone constitutes the southern extremity of the Bündnerschiefer and flyschs which belong to the Valais oceanic zone (Steinmann, 1994a,b) and gives a minimum time bracket for the onset of the final Valais ocean closure as the Arblatsch flysch, the uppermost sediments, was dated as Paleocene-Early Eocene (Ziegler, 1956; Eiermann, 1988). Therefore this zone was underplated below the northern Briançonnais realm (Tambo and Suretta) not before the Early Eocene and most likely in Middle Eocene (49-37 Ma, Gradstein et al., 1995; 46-37 Ma, Odin and Odin, 1990). The D1 ductile deformation (Fig. 10) is linked to the progressive Eocene stacking of the Adula, Tambo and Suretta nappes towards the north-northwest. The absolute ages for the HP metamorphism in the Adula and Cima-Lunga nappes are given around 37-44 Ma (Sm-Nd garnet; Becker, 1993) and $35 \mathrm{Ma}$ (shrimp zircons; Gebauer, 1996) while $\mathrm{K}-\mathrm{Ar}$ and $\mathrm{Rb}-\mathrm{Sr}$ phengite ages, ranging between 45 and $30 \mathrm{Ma}$, are recorded in the Suretta nappe (Purdy and Jäger, 1976; Steinitz and Jäger, 1985; Baltzer, 1989; Schreurs, 1993) and interpreted 

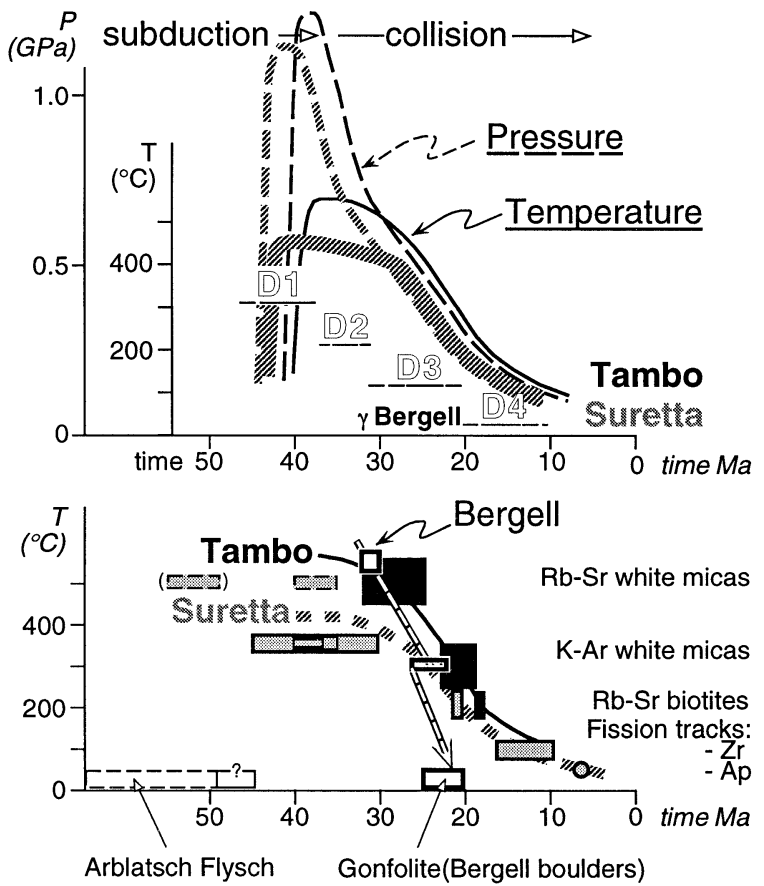

Fig. 10. $P-T-t$ paths for the eastern Switzerland Briançonnais basement nappes (see review of ages and references in Marquer et al., 1994).

as crystallisation ages (as the Suretta nappe never reaches high temperatures; Jäger et al., 1967). The white mica ages in the Suretta nappe were not selected with respect to the microstructural sites and could therefore not be linked precisely to the D1 or D2 ductile deformations. Burial of the thinned continental crust of the eastern Briançonnais margin induced in the basement nappes a ductile thrusting D1 that propagated as isoclinal folds F1 into the cover. D1 is associated with a strong SSENNW stretching lineation and a top to the NNW shear sense. Estimates of the P-T conditions based on phengitic substitution (Massonne and Schreyer, 1987) in D1 mylonitic foliations systematically show HP-LT metamorphic conditions. For example, metamorphic conditions of about $12 \mathrm{kbar}$ and $500^{\circ} \mathrm{C}$ are reached in the Tambo nappe (Baudin et al., 1993). In front of the Tambo and Suretta basement, the pile of crystalline and sedimentary slabs (Areua, Schams, Vignone) represents an accretionary wedge particularly well-developed in the northern Penninic Bündnerschiefer and flysch (Steinmann, 1994a,b). The overall geometry of the frontal slices is related to the closure of the Valais trough. As said before (rotation of Iberia) part of the structural fabric of the Valais accretionary prism could be Late Cretaceous, unless the Cretaceous prism was totally subducted.

\subsubsection{Subduction of the European margin and syn-collision extension (related to slab-break-off?)}

The subsequent deformations D2, D3 and D4 did not modify the overall framework of the nappe pile. After the onset of continental collision, eastwest extension took place along major ductile displacement zones (e.g. Turba Mylonite Zone, Liniger, 1992; Nievergelt et al., 1996). Event D2 is a ductile and heterogeneous deformation associated with a gently E-dipping schistosity and an E-W stretching lineation. Most of the D2 mylonitic zones cross-cut previous contacts and indicate top to the east shearing. As a consequence of the subvertical shortening between the subhorizontal D2 shear planes (Baudin et al., 1993), the gently SE dipping D1 foliation and the pre-Alpine foliations (previously steeply dipping towards the southeast) underwent strong SE-vergent folding. D2 is responsible for the large structure on the top of the Suretta nappe developing both recumbent SE-vergent folds F2 with very low angles between fold axes directed mainly N70 and E-W stretching lineations. This D2 deformation is correlated with the Niemet-Beverin phase described in the Suretta and the Schams nappes by previous authors (Milnes and Schmutz, 1978; Schmid et al., 1990; Schreurs, 1993).

The Mesozoic sediments of the Schams nappes are wrapped around the front of the crystalline basement nappes (equivalent of the Niemet-Beverin post-nappe fold in many works; Milnes and Schmutz, 1978; Schmid et al., 1990; Schreurs, 1993). The rheological contrast between basement and cover became very low during D2 deformation. This led to a very similar style of heterogeneous deformation affecting both basement and cover. The phengitic substitution values measured in the D2 mylonites or in the D2 shear bands indicate pressures decreasing with time and associated with a slight decrease of temperature (Fig. 10). For example, a progressive decrease of pressure and temperature from $1.1 \mathrm{GPa}$ to $0.5 \mathrm{GPa}$ and $550^{\circ} \mathrm{C}$ to $500^{\circ} \mathrm{C}$ is recorded at the bottom of the Tambo nappe (Baudin and Marquer, 1993) and from 1.0 GPa to 0.5 $\mathrm{GPa}$ at $400-450^{\circ} \mathrm{C}$ in the Roffna granite (Nussbaum et 
al., 1998). The ductile D2 mylonites and shear zones were first created at a deep crustal level. The progressively shallower tectonic setting of the Tambo and Suretta nappes during D2 deformation, corresponding to isothermal decompression of about $0.5 \mathrm{GPa}$, is considered a syn-collision extension process caused by the D2 ductile vertical shortening, low-angle detachments toward the east (e.g. Turba Mylonite Zone; Nievergelt et al., 1996) and associated erosion. This progressive extension is defined by eastward-escaping extensional structures produced by the relaxation of a buoyancy disequilibrium in an abnormally thickened accretionary prism (see review of exhumation processes in Platt, 1993). The Turba mylonite, an EW extensional structure (Liniger, 1992; Nievergelt et al., 1996), related to the $\mathrm{D} 2$ event, is cross-cut by the Bergell granodiorite (at Lavinair Crusc, Swiss geogr. coordinates: 772/138), which intruded around $30 \mathrm{Ma}$ (von Blanckenburg, 1990). Therefore D2 must have occurred before $30 \mathrm{Ma}$. The Bergell intrusion is directly linked to the slab break-off (Davies and von Blanckenburg, 1995).

It is important to note that D2 W-E stretching was still active in the upper Penninic nappes while the lower Penninic nappes were progressively transported towards the north-northwest. Moreover, D2 thinning could also explain part of the exhumation of the eastern part of the high-grade Lepontine thermal dome (Bradbury and Nolen-Hoeksema, 1985; Hurford, 1986; Hurford et al., 1989; Merle, 1994).

\subsubsection{Subduction of the European margin and collision (back-thrusts and late extension)}

D3 and D4 deformation events occurred under lower greenschist facies conditions and are much more localised. Event D3 consists of local staircaseshaped folding with steeply S-dipping axial surfaces and $\mathrm{E}-\mathrm{W}$ fold axes. They are preferentially developed in the southern parts of the nappes (Baudin et al., 1993). In the root zone, a conjugate set of E-W-directed thrusts is responsible for the pop-up structure formed by the whole Bergell area (Huber and Marquer, 1996). The D3 event is probably synto post-Bergell granodiorite intrusion. Submagmatic deformation in the Tertiary intrusion, and the folding of the western intrusive contact (Davidson and Rosenberg, 1996), indicate, in deeper levels of the continental crust, kinematics compatible with the pre- viously described D3 phase. D3 deformation during cooling is supported by the south-dipping (north-vergent) thrusts which cross-cut the intrusion when solidified (Rosenberg et al., 1994, 1995). Rapid cooling corresponding to the D3 uplift is also reported from the Suretta and Tambo nappes from 30 Ma until about $20 \mathrm{Ma}$ (Hurford et al., 1989; Marquer et al., 1994). This ductile-brittle D3 deformation was generated by differential uplift of the southern part of the nappe and could be associated with the OligoMiocene vertical movements along the Insubric line which started shortly after the Bergell intrusion (Hurford, 1986; Heitzmann, 1987; Schmid et al., 1989).

The last extensional D4 deformation consists of several NNW-SSE brittle-ductile normal faults, steeply dipping towards the east-northeast and lowering the eastern sides with pluri-hectometric fault throws (e.g. the Forcola fault; Marquer, 1991). This late D4 extensional deformation seems to be a symmetrical structure, coeval with the last Simplon normal faulting in the western part of the Penninic zone (Mancktelow, 1985; Steck, 1984, 1990). Although perhaps not contemporaneous with it, because of the younging of the cooling ages towards the Simplon area (Hurford et al., 1989; Hunziker et al., 1992). D4 could also be linked to late transpression of the Apulian plate along the Alpine arc (Schmid and Froitzheim, 1993). The timing of the D4 phase is not well constrained. We assume that the D4 phase may be around or younger than $20 \mathrm{Ma}$ and is coeval with the dextral strike slip along the Insubric line, which post-dates the uplift of the whole region.

In this part of the Alps, the ongoing syn-collision extension, leading to D2 and D4 structures, is interrupted by a double event corresponding to the Bergell intrusion and the D3 pop-up structures. The progressive deformation during $\mathrm{D} 3$ led to a succession from ductile to brittle-ductile structures.

\section{Western Briançonnais cover nappes}

\subsection{Geological setting of the Préalpes fold-and-thrust belt}

\subsubsection{Introduction}

We shall now move to the review of the Briançonnais sedimentary cover as exposed in western 
Switzerland and in the French Savoie region. This cover was obducted with the frontal part of the accretionary prism in Eocene times and therefore escaped metamorphism. All major geological events are well dated by fossils and offer a perfect complementary data set in regard to what can be defined in the Briançonnais basement nappes in eastern and western Switzerland. The reader can find more detailed descriptions and discussions on the Préalpes Médianes, as well as references, in Masson (1976), Plancherel (1979), Baud and Septfontaine (1980), Trümpy (1980), Mosar et al. (1996), and a quite complete bibliography (more than 950 references) on the World Wide Web site: www-sst.unil.ch/marge and co/prealps/REFEREN.htm.

The Préalpes consist of several klippen along the northern front of the Swiss and French Alps (Fig. 11) from east of the Mythen near Luzern (Switzerland) to the Klippe des Annes near Annecy (France), of which the Chablais Préalpes south of Lake Geneva and the Préalpes Romandes between Lake Geneva and Lake Thun are the most important. It was Schardt $(1884,1893,1898)$ who first demonstrated that the Préalpes were allochthonous. The Préalpes Médianes (Fig. 11) are the largest of several allochthonous structural and palaeogeographic units, among which one can differentiate from top to bottom: (1) the Nappe Supérieure, which itself can be subdivided into four different units: the Gets nappe, the Simme nappe, the Dranses nappe and the Gurnigel nappe (Fig. 4); (2) the Brèche nappe resting on the trailing part of the Préalpes Médianes only (Figs. 11 and 12); (3) the Préalpes Médianes nappe; and (4) the Niesen nappe which exists in the meridional part of the Préalpes only and which today forms the southernmost structural unit (Caron, 1972, 1973; Ackermann, 1979; Bernoulli et al., 1979; Matter et al., 1980; Trümpy, 1980; Caron et al., 1989). The Préalpes Médianes are separated from the Niesen nappe by the 'Zone Sub-médiane' (Weidmann et al., 1976).

Between their original position and their presentday location as klippen, the Préalpes underwent a complex history of palaeotectonics and Alpine tectonics. Due to the opening of the Alpine Tethys ocean to the south, the Briançonnais sedimentation realm of the Préalpes Médianes evolved as a rim basin on the northern passive margin during the
Middle and Late Jurassic (Fig. 12). With the Early Cretaceous opening of the Valais rift to the north, the Briançonnais portion of the sedimentary basin and its basement evolved into a microcontinent until the Eocene (Frisch, 1979; Stampfli and Marthaler, 1990; Stampfli et al., 1991; Stampfli, 1993; Mosar et al., 1996). A variety of palaeotectonic features (normal faults, syn-sedimentary growth structures, inversion structures; Septfontaine, 1995) developed during this palaeotectonic history. Isolated from the Iberian continent during the Palaeogene, the Briançonnais exotic terrane was incorporated into the accretionary prism of the closing Alpine Tethys and the incipient Alpine orogen during the Lutetian-Bartonian.

During its 'Alpine' deformation the Préalpes Médianes nappe was detached from its basement and transported onto the foreland. Equivalent stratigraphic units have been found in the Siviez-Mischabel and Pontis nappes of the Pennine Alps, south of the Rhone valley (Ellenberger, 1950, 1952; Sartori, 1987, 1990; Sartori and Marthaler, 1994; Fig. 11). There the corresponding stratigraphic units (basal series and lateral equivalents) remained attached to their pre-Triassic basement and were intensely deformed. The very low-grade metamorphic conditions (recently dated at 27-28 Ma, M. Jaboyedoff, Lausanne, oral commun., 1998) have their origin in the heat flux induced by tectonic burial beneath overriding nappes (Nappes Supérieures) in the accretionary prism. After having been transported on top of the developing Helvetic nappes, the Préalpes were emplaced in their present-day position in front of the Alpine mountain belt during Oligocene times. Postemplacement and out of sequence thrusting, possibly younger than Oligocene, is observed and can be related to thrusting in the sedimentary substratum and the basement (Stampfli, 1993, 1994; Mosar et al., 1996).

\subsubsection{Sedimentology and palaeotectonics}

The Préalpes Médianes are formed by limestones, dolomites, marls and shales ranging from Triassic to Tertiary in age (Trümpy, 1960, 1980; Badoux and Mercanton, 1962; Plancherel, 1979, 1990; Baud and Septfontaine, 1980; Baud et al., 1989; Borel, 1995; Mosar et al., 1996). The reader can find more detailed descriptions and discussions of the various formations encountered in the Préalpes Médianes in: 

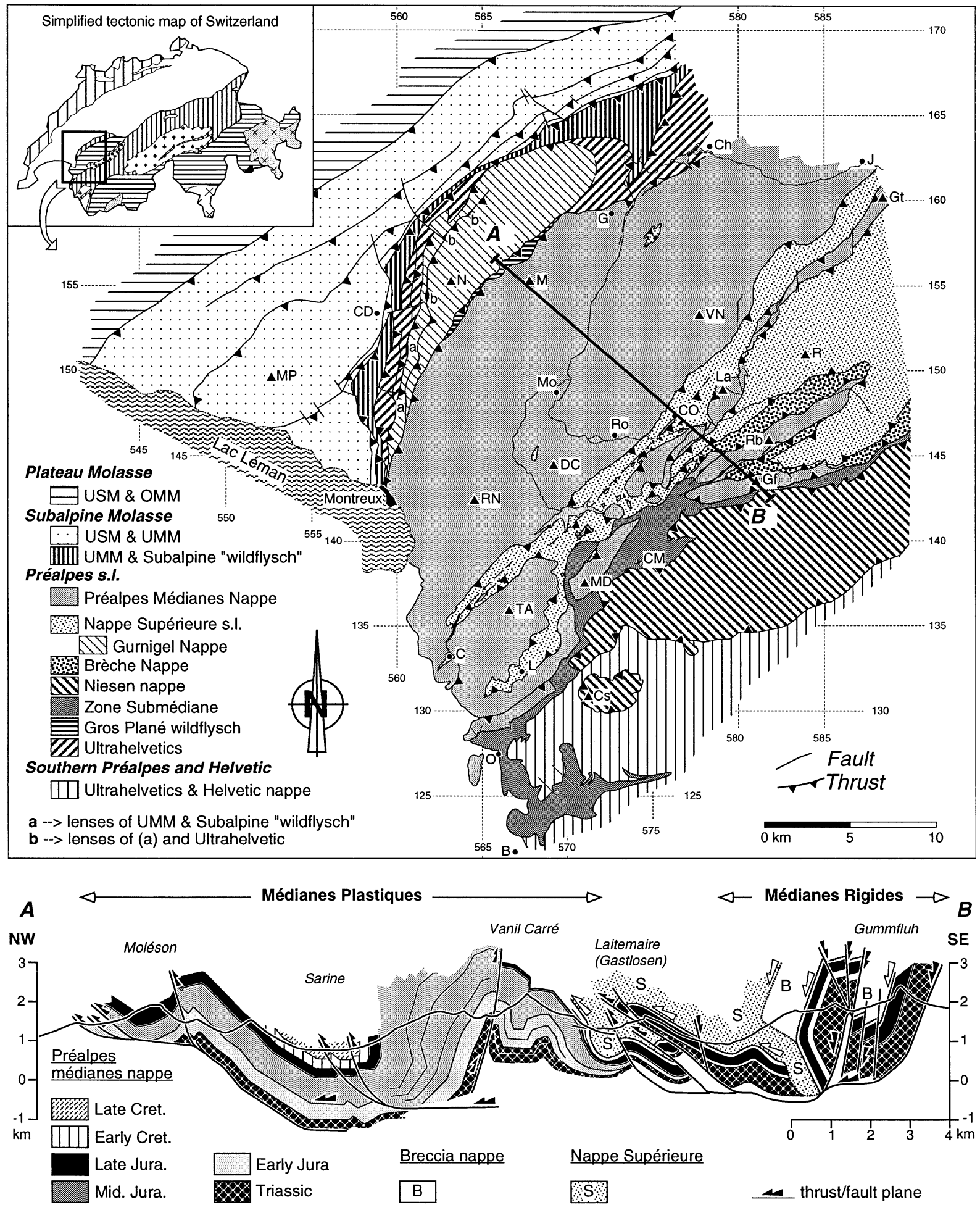

Fig. 11. Detailed map and cross-section of the Préalpes east of lake Geneva. UMM = Lower Marine Molasse; OMM = Upper Marine Molasse; USM = Lower Freshwater Molasse. 


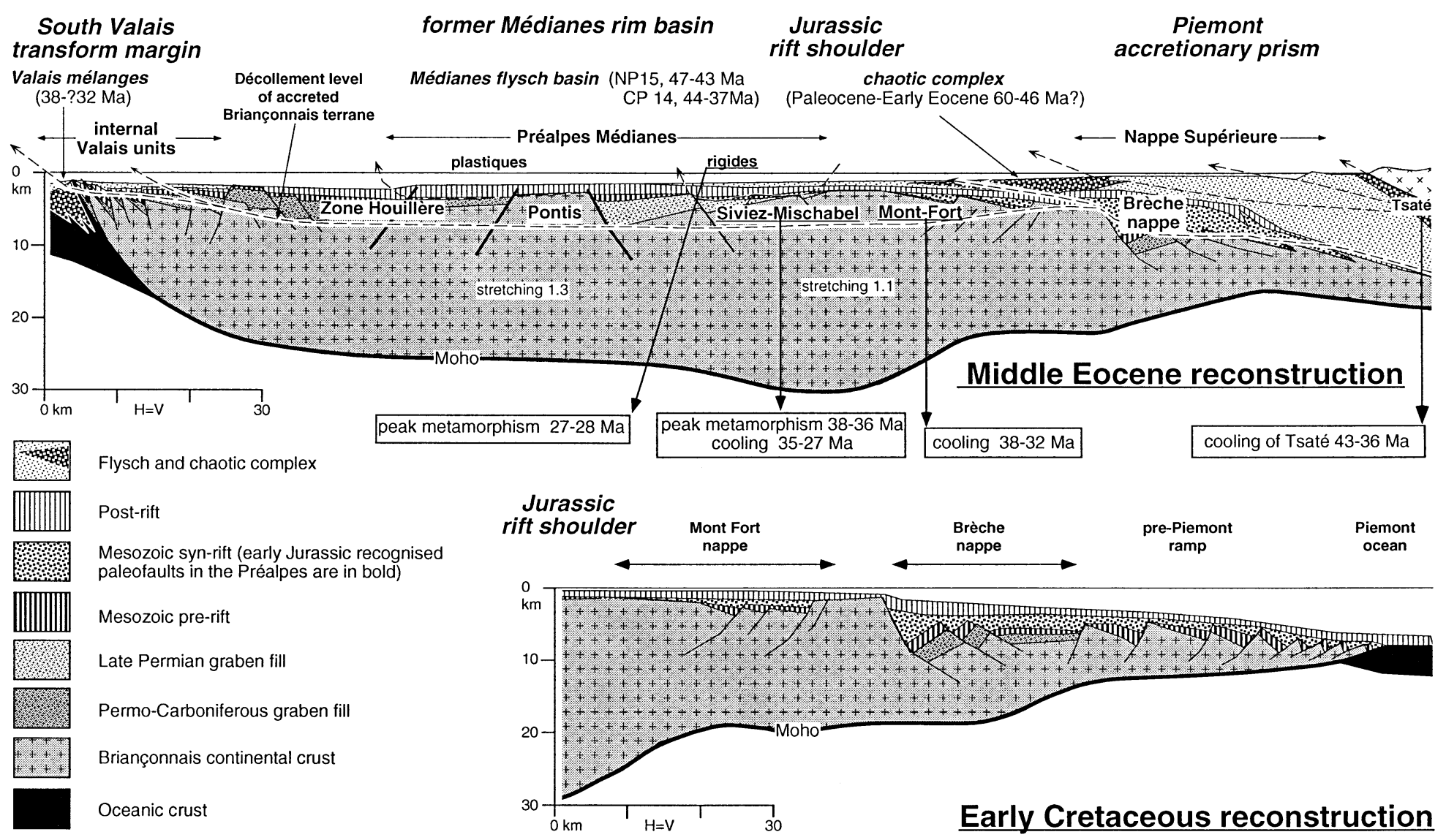

Fig. 12. Reconstruction of the Briançonnais domain in Early Cretaceous and early-Middle Eocene. See text for discussion and references about the timing of events. Stretching factor from Marchant and Stampfli (1997b), assuming original crustal thickness of $30 \mathrm{~km}$. 
Baud (1972, 1987) for the Triassic; Thury (1973), Mettraux (1989), Mettraux and Mosar (1989), and Borel (1998) for the Lower Jurassic (Lias); Furrer and Septfontaine (1977), Furrer (1979), and Septfontaine (1983) for the Middle Jurassic (Dogger); Weiss (1949), Isenschmid (1983), Heinz (1985), and Heinz and Isenschmid (1988) for the Upper Jurassic ('Malm'); Boller (1963) for the Lower Cretaceous (Neocomian); Caron and Dupasquier (1989), and Python-Dupasquier (1990) for the middle Cretaceous; Guillaume (1986) for the upper CretaceousTertiary.

The Préalpes Médianes are separated into two major sedimentation realms clearly differentiated since the Liassic and separated by two minor domains (Fig. 13): to the north-northwest, in the Médianes Plastiques, a large basin is marked by a thick Jurassic sequence. To the south this subsiding domain turns into a ramp - associated with a continuously active structural high - that gives way to a platform and lagoonal environment in the Médianes Rigides (Baud and Septfontaine, 1980).

The sedimentary record in the two major domains is quite different (Fig. 13). It reflects the important role played by the rift shoulder of the Alpine Tethys ocean since late Liassic, separating the rim basin to the north-northwest from the margin s.str. to the south-southeast (Fig. 12). Sedimentary sequences of Middle Triassic age in the Médianes Rigides are formed by massive, sometimes dolomitic limestones developed in a lagoonal and inter- to supratidal environment. In the Médianes Plastiques the stratigraphic sequence starts with interbedded formations of Late Triassic shales and dolomites. The depositional environment is very shallow to lagoonal.

Rhetian limestones including tempestites witness the onset of crustal extension and may be as thick as $200 \mathrm{~m}$ (Borel, 1998). Lumachellic limestones, oolites, sandy, as well as entrochal calcarenites and spongolites indicate a general deepening of the depositional environment during early to middle Lias. Locally, polyphase megabreccias, karsts and fissure fillings developed (Baud and Masson, 1975; Baud et al., 1979; Mettraux and Mosar, 1989; Hürlimann et al., 1996; Poinssot et al., 1997). The active development of syn-sedimentary normal faults created small depositional domains, with series up to several hundred metres thick. During Toarcian times, interbedded black marls and black argillaceous limestone were deposited in an anoxic environment. An accelerated subsidence during the late Liassic resulted in the appearance of the deep argillaceous Cancellophycus limestone facies in the Médianes Plastiques. This deposition continued into the Middle Jurassic (Dogger) with sporadic appearances of oolitic or spatic and sandy limestone. Slumps and turbidites are frequent in a ramp setting dipping towards the north. To the south, in the Médianes Rigides, a lagoonal facies developed starting in the Bajocian with its marly and argillaceous limestone containing Mytilus and coal layers. This facies is transgressive on Triassic limestone in this meridional area. From the Middle Jurassic onward the rim basin geometry is well established, characterised by a north-facing progradation, away from the opening Alpine Tethys in the south.

During the Late Jurassic $200-300$ m of massive, thick-bedded limestone were deposited, with facies ranging from hemipelagic limestones with interbedded calcareous turbidites to shallow platform carbonates in the Médianes Rigides (Heinz and Isenschmid, 1988). These sediments rest in stratigraphic unconformity on Triassic limestones in the southern part of the Médianes Rigides and indicate the general drowning of the former rift shoulder at that time (Borel, 1998). This ubiquitous, competent massive limestone controls the structural development of folds and thrusts.

Cherts are more frequent towards the top, with a progressive transition to the Lower Cretaceous (Neocomian) pelagic limestones interbedded with cherts and marls. The sediments are strongly folded, making it difficult to determine the original thickness (estimated at 100-150 m). The succession thins towards the centre of the basin and pinches out to the southeast, suggesting deposition along a slope.

An important change occurred during the lateEarly Cretaceous as shown by the appearance of pelagic and hemipelagic argillaceous, anoxic sediments and a large decrease in sedimentation rate. The interbedded limestones and shales (grey, red and green) of the Late Cretaceous/early Tertiary Couches Rouges Group indicate yet another major change in environment. These sediments are deposited in a drowned and starved realm, possibly reaching the CCD. Important stratigraphic gaps 
(a) ${ }_{\mathrm{NW}} \leftarrow$ Subbriançonnais $\rightarrow$

Briançonnais

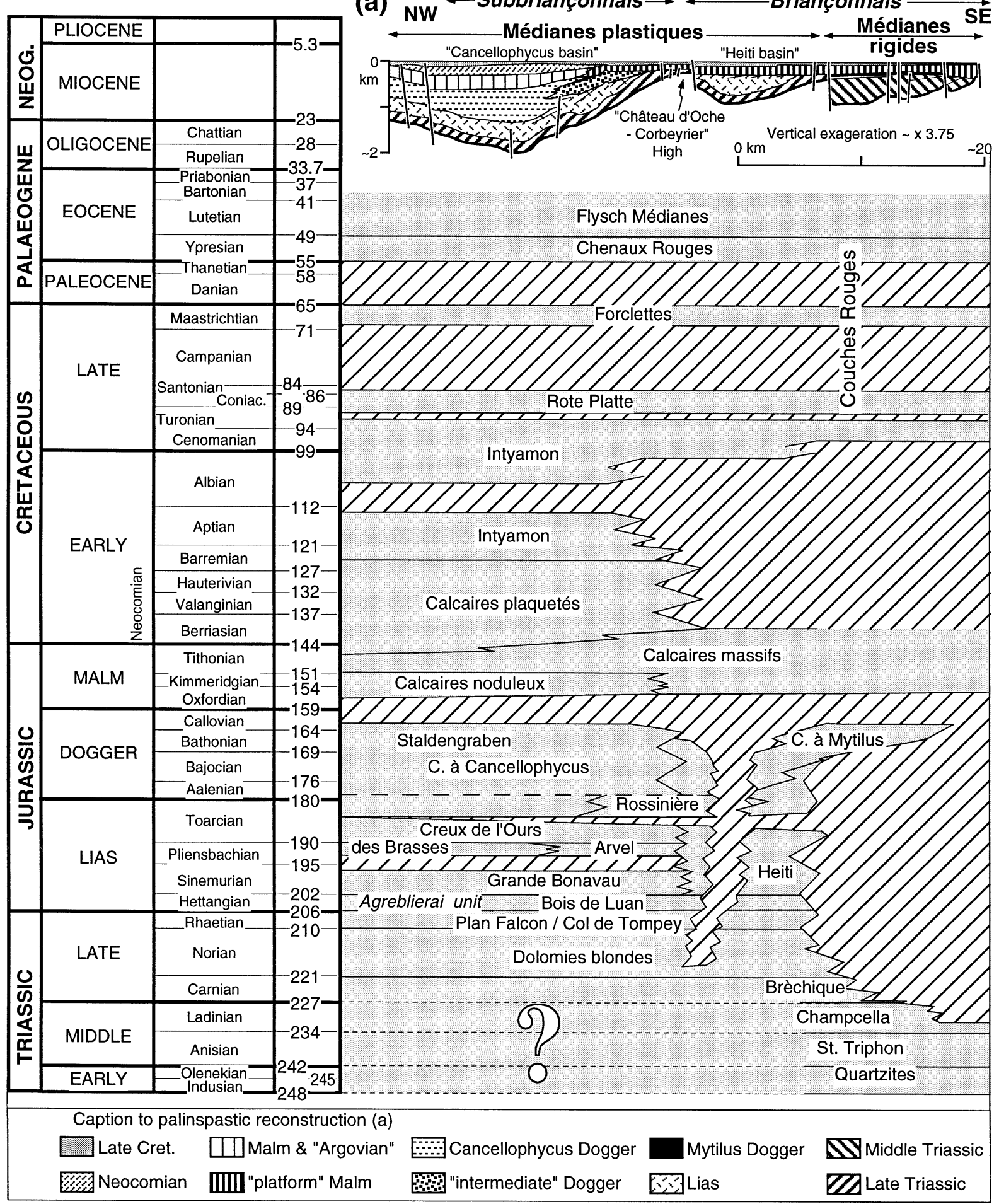


(Fig. 13) during this Late Cretaceous to Eocene period are recorded by hardgrounds and condensed beds. The Couches Rouges Group rapidly changes upward to schistose sand-rich flysch deposits of Lutetian age, thus ending the sedimentation history in the Préalpes Médianes.

\subsubsection{Regional structural geology of the Préalpes Médianes}

The Préalpes Médianes underwent thin-skinned tectonics and show the typical characteristics of a foreland fold-and-thrust belt (Fig. 11; see Mosar and Borel, 1992; Mosar, 1994, 1997; Mosar et al., 1996, and references therein). The foreland propagating thrust sequence developed above a basal décollement in Triassic evaporites, mainly during its incorporation in the accretionary prism of the closing Alpine Tethys. It is along this décollement that the Préalpes have been detached from their basement and partly carried over the Helvetic units onto the NNW Alpine foreland. Two major transport directions, top-to-the-N/NW, towards the Alpine foreland have been determined. At the western termination late movements to the west in the complex frontal imbricate of the Médianes Plastiques can be demonstrated (Mosar, 1994; Mosar et al., 1996).

The Préalpes Médianes nappe is subdivided into the Médianes Plastiques, forming the frontal (NW) part of the nappe and Médianes Rigides, forming the trailing (SE) part of the nappe (Fig. 11). A domain with intermediate characteristics exists between the Médianes Rigides and Plastiques: the Gastlosen range. The Médianes Plastiques are composed of a succession of large-scale fault-related folds, whose trends vary from $\mathrm{E}-\mathrm{W}$ in the eastern part of the nappe to NNE-SSW, and even N-S, in the western part of the nappe. Folds and associated thrust planes die out along-strike, resulting in 'en échelon' fold-thrust structures. The trailing part of the nappe, the Médianes Rigides, is formed by one major, in some places one or two minor, imbricated thrust slices that dip to the N/NW. These slices form faultbend-like folds that are cut by a large backthrust in their ramp portion. The imbricates dip gently to the north in the Simmental area of the eastern Préalpes Médianes and are steeply dipping in the western region near Châteaux-d'Oex (Fig. 11). Different types of backthrusts have developed: large backthrusts resulting from the inversion of former normal listric, syn-sedimentary faults; backthrusts associated with pop-up structures developed in large-scale fold cores; and backthrusts developed at the transition between ramps and flats in thrust hangingwall blocks.

\subsubsection{Transported metamorphism and internal deformation in the Préalpes Médianes}

Numerous studies in recent years (see Mosar, 1988; Zahner and Mosar, 1993; Jaboyedoff and Thélin, 1995) have shown that the Préalpes Médianes underwent a very low-grade metamorphism. This metamorphism varies from diagenesis in the north (i.e. in the Médianes Plastiques) to epizone in the south (i.e. in the Médianes Rigides, $300-400^{\circ} \mathrm{C}$ ). This zonation also exists from top to bottom in the southern part of the Préalpes nappe stack. The epizonal conditions contrast with the diagenetic conditions preserved in the top part of the underlying Niesen nappe. Metamorphism in the Préalpes Médianes is thus a transported feature! Similar discontinuities in metamorphism occur between the Niesen nappe and the underlying Ultrahelvetic units, and between the Ultrahelvetic units and the underlying Helvetic nappes (Burkhard, 1988).

Metamorphism of the Préalpes Médianes occurred during thrusting of the overlying nappes and subsequent burial. In order to explain the epizonal temperatures above $300^{\circ} \mathrm{C}$ with a geothermal gradient of $\sim 30^{\circ} \mathrm{C} / \mathrm{km}$, the Préalpes Médianes would thus have to have been buried to a depth of $10 \mathrm{~km}$ in their trailing portion, whereas the frontal portion was probably only buried to a depth of $\sim 4$ to $5 \mathrm{~km}$. These could be minimum estimates of burial depth, since in the context of subduction in an accretionary prism the geothermal gradient would have been significantly lower than normal, although slab detachment in the Early Oligocene would have increased this gradient.

Fig. 13. Stratigraphic scheme for the Préalpes Médianes (modified from Mosar et al., 1996 and Borel, 1998). Formation names are shown; hatch pattern indicates erosion and/or non-deposition; timescale after Gradstein et al. (1995). Palinspastic reconstruction (a) modified from Baud and Septfontaine (1980). 
$\mathrm{Rb} / \mathrm{Sr}, \mathrm{K} / \mathrm{Ar}$ and ${ }^{40} \mathrm{Ar} /{ }^{39} \mathrm{Ar}$ dating of white micas in the Médianes Rigides from Triassic and Middle Jurassic limestone yielded ages of $\sim 60$ to $80 \mathrm{Ma}$ (the Gummfluh imbricate, Masson et al., 1980; Huon et al., 1988; Cosca et al., 1992; the Amselgrat imbricate, De Coulon, 1990). Results from a recent investigation by M. Jaboyedoff and M. Cosca (oral commun., 1998, Lausanne) show that these ages are mixed ages and that the age of the metamorphism in the Médianes Rigides is early-Late Oligocene (27-28 Ma).

The internal deformation of the Préalpes Médianes limestone has been quantified using the distortion of pellets and ooids as well as twinning of sparitic calcite (Mosar, 1989). The strain intensity in the frontal Médianes Plastiques is very low and dominated by transgranular deformation mechanisms, mainly pressure solution, with weak development of calcite twins. This deformation corresponds to an 'early' shortening parallel to bedding, emphasised by the development of tectonic stylolites. The strain increases towards the Médianes Rigides, where intragranular deformation mechanisms, such as twinning (numerous large, curved and twinned twins) and dynamic recrystallisation, prevail. The most intense strain is associated with thrusting along the basal décollements of the Préalpes Médianes nappe and of the overlying Brèche nappe. The maximum finite extension direction is sub-parallel to the thrust planes in their vicinity. A sub-horizontal cleavage, which makes only a small angle to the bedding planes, developed in the same context. Elsewhere in the Médianes Rigides, the extension direction dips at a high angle to the thrust planes, reflecting early layer-parallel shortening similar to that recognised in the Médianes Plastiques.

\subsubsection{Transitions from the Préalpes Médianes to neighbouring structural units}

The transition from the Préalpes Médianes nappe to the underlying and overlying structural units is marked by mélange units which are often termed wildflysch in the Alpine literature (Homewood and Caron, 1982). The contacts are characterised by special types of units and rocks such as mélanges and rauhwackes (cornieules) associated with anhydrites. For the Préalpes Médianes two groups of mélanges can be distinguished: the supra-Préalpes Médianes mélanges mostly related to the emplacement of the
Nappe Supérieure and the infra-Préalpes Médianes mélanges (they are mostly supra-Helvetic) that are linked to the Préalpes Médianes emplacement.

The mélange zones. The Préalpes Médianes rest on top of the Helvetic nappes in the south and the Subalpine Molasse and flysch in the north. Along this contact we observe the Ultrahelvetic and the 'Zone Submédiane' units which have been interpreted as mélanges similar to those formed in accretionary prisms (Jeanbourquin, 1992, 1994; Jeanbourquin et al., 1992). They were subsequently strongly overprinted by Alpine tectonics, especially during nappe emplacement. We shall review these mélanges starting from the external to the internal.

(1) The Ultrahelvetics can be subdivided into upper and lower Ultrahelvetic mélanges. The lower ones are always associated with a specific Helvetic nappe, whereas the upper ones do not show this systematic correspondence and their kinematic development appears to be closely related to the evolution of the Préalpes nappe stack (Jeanbourquin, 1991a,b, 1992, 1994; Jeanbourquin et al., 1992). These Ultrahelvetics are formed by a succession of units and slivers (or nappes) in each of which a complete (though sometimes dismembered) stratigraphic sequence is defined (Badoux, 1963, 1965; LempickaMünch and Masson, 1993). Their palaeogeographic origin is located to the south of the Helvetic domain and in the external Valaisan realm (Jeanbourquin and Burri, 1991). In the meridional Préalpes they are located between the Préalpes nappes and the Helvetic nappes. The Ultrahelvetic mélange is also found beneath (Badoux and Norbert, 1952) and in front of the Préalpes Médianes nappe (Weidmann, 1985, 1992).

(2) The Zone Submédiane (Weidmann et al., 1976) is found below the basal décollement of the meridional part of the Préalpes Médianes. It forms the contact with the underlying Niesen flysch nappe in the central and eastern Préalpes Romandes and the Ultrahelvetic units in the western part of the Préalpes Médianes along the Rhone valley. This zone is a mélange of blocks of various lithologies recording a continuous sedimentation from Triassic to Eocene. Its origin has tentatively been located in the Valais oceanic domain of which it represents the suture, therefore, north of the Préalpes Médianes depositional realm (Weidmann et al., 1976; Stampfli, 1993; 
Jeanbourquin, 1994). The presence of Liassic breccias, pelagic Dogger and Malm give a slope-to-basin character to this sequence, the presence of Urgoniantype limestone allows this sequence to be positioned south of the Helvetic domain. This is one of the arguments used by Stampfli (1993) to propose a duplication of the north Alpine Tethys margin in the western Alps transect. The Valais ocean rifting is documented by the Late Jurassic/Early Cretaceous spilite and the Albian sandstones and breccias. Very large outcrops of anhydrites and gypsum deposits are present along the Rhone valley between Ollon and Bex. These anhydrites, of which some were formerly attributed to the Ultrahelvetic units, can now be considered part of the Zone Submédiane. Superposed folding of the anhydrite bands is evidence of multiphase deformation (Zahner and Mosar, 1993; Mosar et al., 1996). A wildflysch forms the matrix of the zone together with the gypsum and cornieules. Some cannibalism of mélanges can be demonstrated, such as the Paleocene Trom Breccia (with basement and Tithonian limestone clasts) reworked in an Eocene wildflysch. A Tertiary flysch with Nummulites, Discocyclines and Globorotalia is also present. The deformation, as well as the mixing of the mélanges, has largely been explained by thrusting along the Préalpes Médianes basal décollement. Thus, the Zone Submédiane mélange is primarily tectonic in origin (Jeanbourquin op. cit.).

(3) The 'Flysch with Couches Rouges lenses' (Chaotic complex in Fig. 12) is found on top of the Préalpes Médianes as well as associated with the overlying Brèche nappe and/or the Nappe Supérieure. These complexes can form rather continuous horizons and primarily contain characteristic slivers of the hemipelagic Couches Rouges Group.

\subsection{Geodynamic evolution of the western Penninic Alps}

\subsubsection{Subduction-obduction processes}

Subduction and obduction processes affecting the oceanic sequences of the Piémont ocean are shown in Fig. 4. This figure together with Fig. 5 is based on spreading rates obtained from the central Atlantic magnetic anomalies which allow the opening of the Alpine Tethys to be defined. The rates of convergence between Africa and Europe are also derived from the Atlantic magnetic anomalies and reported along a transect perpendicular to the western Alps.

The time sequence of incorporation of the different terranes on a western Alps transect is well established based on the age of associated flysch deposits (Caron et al., 1989).

In the Piémont domain on a western Alps transect, the Gurnigel flysch was deposited from the Maastrichtian until the Middle Eocene (Caron et al., 1980a,b) and followed by the chaotic complex of likely Middle Eocene age (Steffen et al., 1993) which includes elements from the Briançonnais southern margin (Brèche nappe).

In the Briançonnais domain the deposition of the Médianes flysch (Caron et al., 1980a; Guillaume, 1986; Hable, 1997) lasted at least until Lutetian time (NP 15, 47 to 43 Ma or CP 14, 43-37 Ma, according to Wei and Peleo-Alampay, 1993). It is a rather distal flysch deposit, precluding any deposition on an already detached substratum. Thus the subduction of the Briançonnais domain did not take place before the late-Middle Eocene, as is confirmed by the fact that metamorphic ages from the Briançonnais basement in Valais start at around $38 \mathrm{Ma}$ (Fig. 10) (Markley et al., 1995, 1998). Slivers of basement with part of their cover were detached from the subducting slab and underplated; they form presently the bulk of the middle Penninic domain (Escher et al., 1997). Part of the cover was detached from the basement and incorporated into the still-active accretionary prism to form the exotic Préalpes Médiannes domain (Mosar et al., 1996).

Elements from the Valais ocean were then accreted and are represented by the 'Valaisan trilogy' (Aroley, Marmontains, Saint Christophe; Burri, 1958) made of poorly dated clastic deep-sea sediments outcropping at present in the Sion-Courmayeur zone. MORB from the Valais ocean are found in a few places in the Valais and in eastern Switzerland in the Bündnerschiefer (Dürr et al., 1993). The obduction of oceanic material could witness the Cretaceous very oblique subduction phase of the Valais ocean, but no metamorphic Cretaceous ages or Cretaceous mélanges have been found so far. However the St. Christophe flysch or Flysch de Tarentaise is recognised as sedimented on a structured substratum (e.g. Antoine, 1971; Gély, 1989; Fudral, 1996) and its age is Campanian or younger, which fits the closure of 


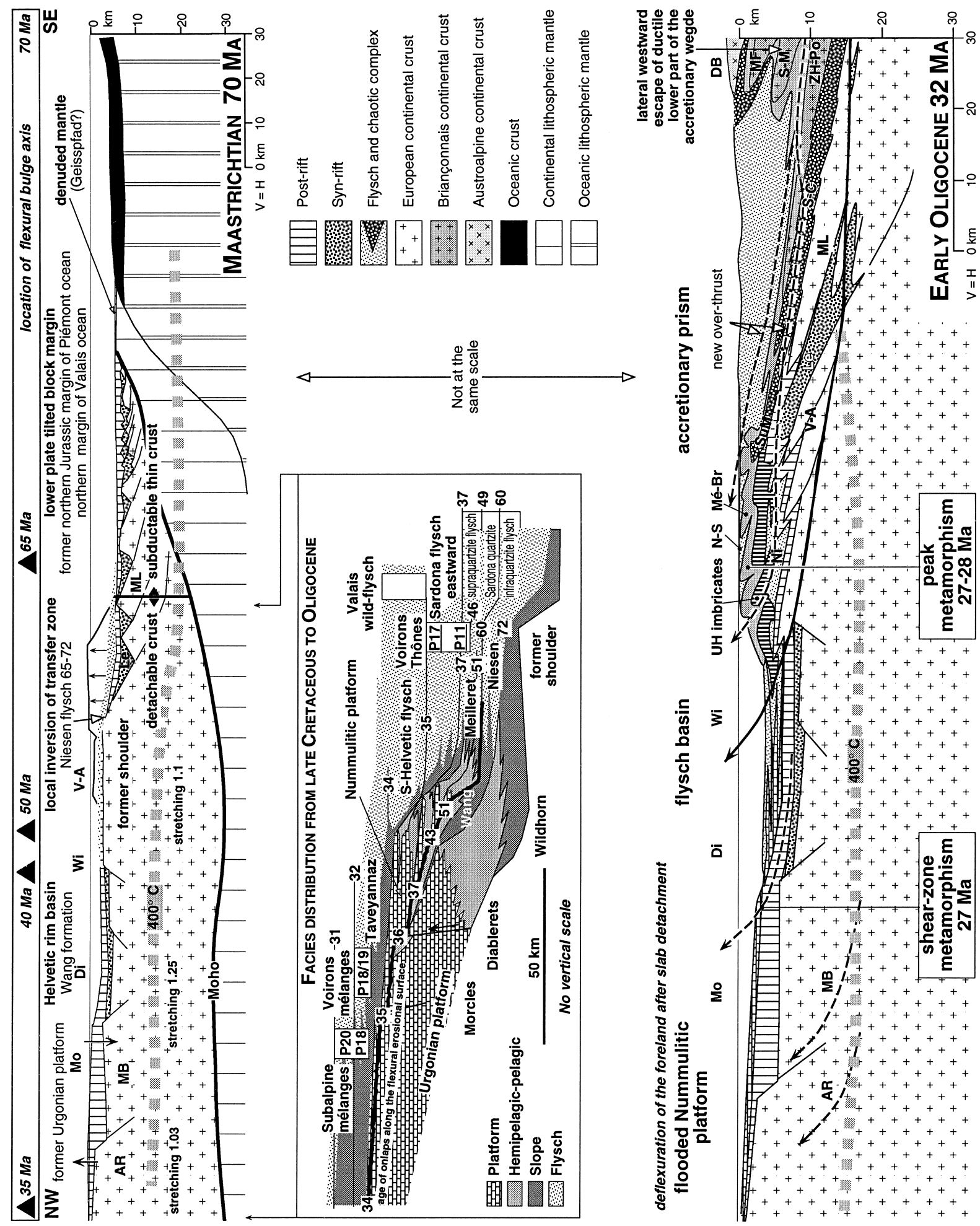


the Valais domain at that time due to the opening of the Biscay ocean (Fig. 2). HP metamorphism is recorded in these sequences but not dated yet. HP ages in eastern Switzerland (Bündnerschiefer; Goffé and Oberhänsli, 1992) are between 44 and $35 \mathrm{Ma}$ (see above). Cooling ages in the Valais sequences of the French Alps are centred around $33 \mathrm{Ma}$ (Cannic, 1996). If a Late Cretaceous accretionary mélange existed it was certainly reworked and incorporated into younger mélange possibly affected by HP metamorphism. Recent microfossil findings in the internal Valais mélanges (the external Zone Houillère) allow the closure of the remnant Valais ocean to be determined. Late Eocene to possibly Early Oligocene pelagic microfauna has been found in these mélanges (M. Sartori, oral commun., 1998, Geneva; Bagnoud et al., 1998) which reworked mainly the Briançonnais basement (Zone Houillère) and parts of its Jurassic cover (e.g. Pierre Avoi sequence). Palaeogene and Cretaceous (not older than Aptian) microfauna are also reworked, but as no Cretaceous element from the Subbriançonnais basin are reworked this implies (a) the presence of pelagic deposits of this age in the Valais domain (the Valais trilogy), and (b) that the Subbriançonnais cover nappes (Préalpes Médiannes) were still attached on their substratum in the Early Oligocene. In this context it is possible that part of the 'ophiolitic' Versoyen sequence is effectively of Carboniferous age (Cannic, 1996; Cannic et al., 1996) and reworked as major olistolites into this Late Eocene/Oligocene mélange.

Incorporation of the Helvetic margin into the prism (Fig. 14) is well constrained by the ages of the south Helvetic flysch (e.g. Jeanbourquin and Burri, 1991; Jeanbourquin, 1994) and their possible equivalent in France (e.g. Niélard flysch; Gély, 1989) and the Sardona flysch in east Switzerland (Lihou, 1996). It can be placed after the Priabonian since the Valais mélange is dated as Early Oligocene and the Ultrahelvetic flysch has been dated in the western Alps as Late Eocene (37 to $34 \mathrm{Ma}$; e.g. Kindler,
1988; Charollais et al., 1993), but the Priabonian fauna is described as reworked in the Niélard flysch (Gély, 1989). Most of the attenuated crust from the Helvetic margin was subducted and little is known about its syn-rift sequences. The highly metamorphic Lebendun conglomerates of the Simplon region have been interpreted as syn-rift deposits (Spring et al., 1992). Their obducted equivalent is represented by the sub-Niesen Dogger sequence from le Sepey (Homewood, 1974; Badoux and Homewood, 1978), made of pebbly mudstone, conglomerates (with Triassic and basement clasts) and thick turbiditic sandstones. The Monte Leone crustal nappe is considered a former tilted block from that margin. It is presently in tectonic contact with mantle rocks from the Geisspfad massif (Keusen, 1972; Pastorelle et al., 1995), representing denuded mantle from the toe of the margin. The Zone Submédiane elements (see above) are to be placed on this distal part of the Helvetic margin, the younger flysch deposits there are at least of Middle Eocene age. General metamorphism of the south Helvetic domain ranges in age from 30 to 20 Ma (cooling ages; Steck and Hunziker, 1994) and mylonites from the Helvetic nappes have been dated between 32 and $13 \mathrm{Ma}$ (Kirshner et al., 1996).

Further subduction of the Helvetic rim basin led to the decoupling of major parts of its crystalline basement (Mont Blanc and Aiguilles Rouges massifs; Fig. 14). This decoupling was made possible by the increased heat flux following slab detachment around 35-33 Ma (Wortel and Spakman, 1992; Stampfli and Marchant, 1995, 1997). This detachment corresponds to the emplacement of the peri-Adriatic intrusives (e.g. Bergell intrusion) and the rapid Early Oligocene transgression on the Helvetic domain following a temporary de-flexuring of the lower plate and which created an underfilling of the foreland basin at that time (Sinclair, 1997). This phenomenon allowed further subduction of the European plate (Marchant and Stampfli, 1997a). Younger phases of advance of the prism into the European margin are

Fig. 14. Reconstruction of the Helvetic margin in Maastrichtian and Early Oligocene. See text for discussion and references about the timing of events. Stretching factor from Loup (1992). $A R=$ Aiguilles rouges massif; $D i=$ Diablerets nappe domain; $D B=D e n t$ Blanche nappe; Le = Lebendun sequence; $M B=$ Mont Blanc massif; $M F=$ Mont Fort nappe; $M o=$ Morcles nappes domain; $M e ́-B r=$ Médianes and Brèches nappes; $M L=$ Monte Leone nappe; $N i=$ Niesen nappe; $N-S=$ Nappes Supérieures; $S$ - $C=$ zone Sion-Courmayeur; $S$ - $M=$ Siviez-Mischabel nappe; $S u M=$ zone Submédianes; $V-A=$ Verampio-Antigorio nappes; $W i=$ Wildhorn nappe domain; $Z H$ - $P o=$ zone Houillère, Pontis nappes. 
well recorded by the Molasse basin deposits (e.g. Schlunegger et al., 1997) and the obduction of the Jura (e.g. Burkhard and Sommaruga, 1998).

\subsubsection{Subduction of the Piémont ocean and evolution of the flexural bulge}

We reported the evolution of the flexural bulge in time along a convergent Alpine transect as shown in Fig. 5. In the Briançonnais and Helvetic domains the flexural bulge can be detected through a good preservation of the sedimentary sequences.

The flexural bulge affected the Briançonnais domain in the Late Cretaceous and could have been responsible both for the major hiatuses in the sedimentary record at that time (Figs. 3 and 13) and for the very condensed nature of the section as a whole (Couches Rouges, Guillaume, 1986). The Valais ocean oblique subduction at that time would have affected this area in a similar fashion, due to the high buoyancy of the young Valais oceanic crust. Therefore it is difficult to relate this uplift and associated breccia deposits to one event or the other. Late Cretaceous to early Tertiary breccias are rather limited in the Subbriançonnais (Hürlimann et al., 1996) but quite widespread in the French Briançonnais (Chaulieu, 1992). The flexuring might also be responsible for the emplacement of withinplate basalts in Maastrichtian-Paleocene times in the Briançonnais domain (E. Deville, pers. commun., 1992; Deville, 1993), although they could also be related to the onset of separation of the Briançonnais from the Iberian plate.

The distal Helvetic margin was affected by vertical movements (mainly inversion of former normal faults) already in the Late Cretaceous (Figs. 5 and 14) characterised by the Niesen flysch deposits (Ackermann, 1986) that we link to the Valais ocean subduction. The general onset of widespread inversion on the European margin and further north starting in the Late Cretaceous (Ziegler et al., 1995) implies intra-plate stress generation due to recoupling of the subducting plate with the upper plate. This is certainly true for the Valais subduction where the subducting oceanic material is young and buoyant and also in the Meliata subduction zone where the Austroalpine (e.g. Schweigl and Neubauer, 1997) and inner Carpathian microcontinents (e.g. Plasienka, 1996) started subducting in the Early Cretaceous.
A general emersion of the Helvetic-Dauphinois and Subalpine domains took place at least as early as Paleocene time (Allen et al., 1991; Lihou and Allen, 1996; Burkhard and Sommaruga, 1998) and can be related to the only flexural bulge effect. In view of different transgressive patterns of the Nummulitic platform onto the retreating forebulge (Herb, 1988; Menkweld-Gfeller, 1997), it could be suggested that the collision was slightly oblique and diachronous, being older eastward than westward.

\section{Discussion}

\subsection{Incorporation of the Briançonnais terrane in the accretionary prism, implications}

In view of the data presented above, this incorporation can now be quite precisely placed in Middle Eocene time, and certainly not before $45 \mathrm{Ma}$. This date comes from the age of the Médianes flysch (43-47 Ma) and chaotic complex (younger than 46 $\mathrm{Ma})$ as well as from the metamorphism of the Briançonnais basement between 32 and 38 Ma for the Penninic nappes of the Valais and between 35 and $40 \mathrm{Ma}$ for the east Switzerland nappes. Westward, in the French Briançonnais, Priabonian limestones followed by a chaotic complex are known (e.g. Deville, 1987), giving an even younger age of incorporation there between 37 and $34 \mathrm{Ma}$. The most eastern Briançonnais elements (i.e. Sulzfluh and Falknis cover nappes, northeast of Tambo and Suretta) have a lithological sequence very similar to the Préalpes Médianes (Trümpy, 1970, 1980). These sequences comprise the Couches Rouges formations terminated by a flysch sequence dated as Late Paleocene-Early Eocene in the Falknis nappe. However, the Couches Rouges of the Sulzfluh nappe are also dated as Paleocene. If we extrapolate the formation ages from the Préalpes Médianes, where the Paleocene Chenaux Rouges formation reaches the Middle Eocene, the Briançonnais flysch of eastern Switzerland could be younger than Early Eocene as the fossils in such deposits are usually reworked. Trümpy (1980) suggested the incorporation of these eastern Briançonnais elements during his Meso-Alpine phase which he places in Late Eocene. It could be suggested, however, that this incorporation into the accretionary 
prism was diachronous, starting in the Lutetian (49 to $41 \mathrm{Ma}$, Gradstein et al., 1995; 46 to $40 \mathrm{Ma}$, Odin and Odin, 1990) in the east and finishing in Priabonian (37 to $34 \mathrm{Ma}$ ) in the west.

The implications are as simple as they are fundamental. Regarding possible HP-LT metamorphism that some Briançonnais basement units could have developed, this metamorphism should be necessarily younger than 45 to $49 \mathrm{Ma}$. Even if the toe of the Briançonnais margin entered the accretionary prism around 47-49 Ma, with a convergence rate of 2.0 $\mathrm{cm} /$ year and a Benioff zone at 35 to $45^{\circ}$, it would take 3 to $5 \mathrm{Ma}$ for these rocks to reach HP-LT conditions, thus not before $45 \mathrm{Ma}$, or even $42-43 \mathrm{Ma}$ in the case of UHP rocks.

Most HP/LT ages measured so far in the internal massifs (Monte Rosa, Grand Paradis, Dora Maira) are older than $45 \mathrm{Ma}$ (see Dal Piaz and Lombardo, 1986 and Hunziker et al., 1992 for a review of older ages, and Duchêne et al., 1997a for younger ages). A younger Lu-Hf age (32.8 Ma, Duchêne et al., 1997a) obtained for the UHP rocks of Dora Maira is a cooling age (Lardeaux, oral comm. Biella, see Duchêne et al., 1997b). Therefore it cannot be used to prove the Penninic (Briançonnais) origin of these rocks, which were buried to nearly $150 \mathrm{~km}$. A 49.2 Ma age obtained by the same authors on the Monviso ophiolites proves that the Alpine Tethys oceanic crust was still being subducted around that time. The middle and upper Penninic nappes must have reached blueschist or eclogitic metamorphism during the subduction of the Alpine Tethys ocean, not during the collisional phases (Fig. 15). Being of continental origin, their motherland could only be the southern Piémont margin (Adria or Austroalpine) not the Briançonnais.

We hope that this will help conclude the ongoing discussion about the existence or non-existence of an eoalpine HP-LT metamorphic phase (e.g. Tilton et al., 1989; Deville, 1993; Bowtell et al., 1994),

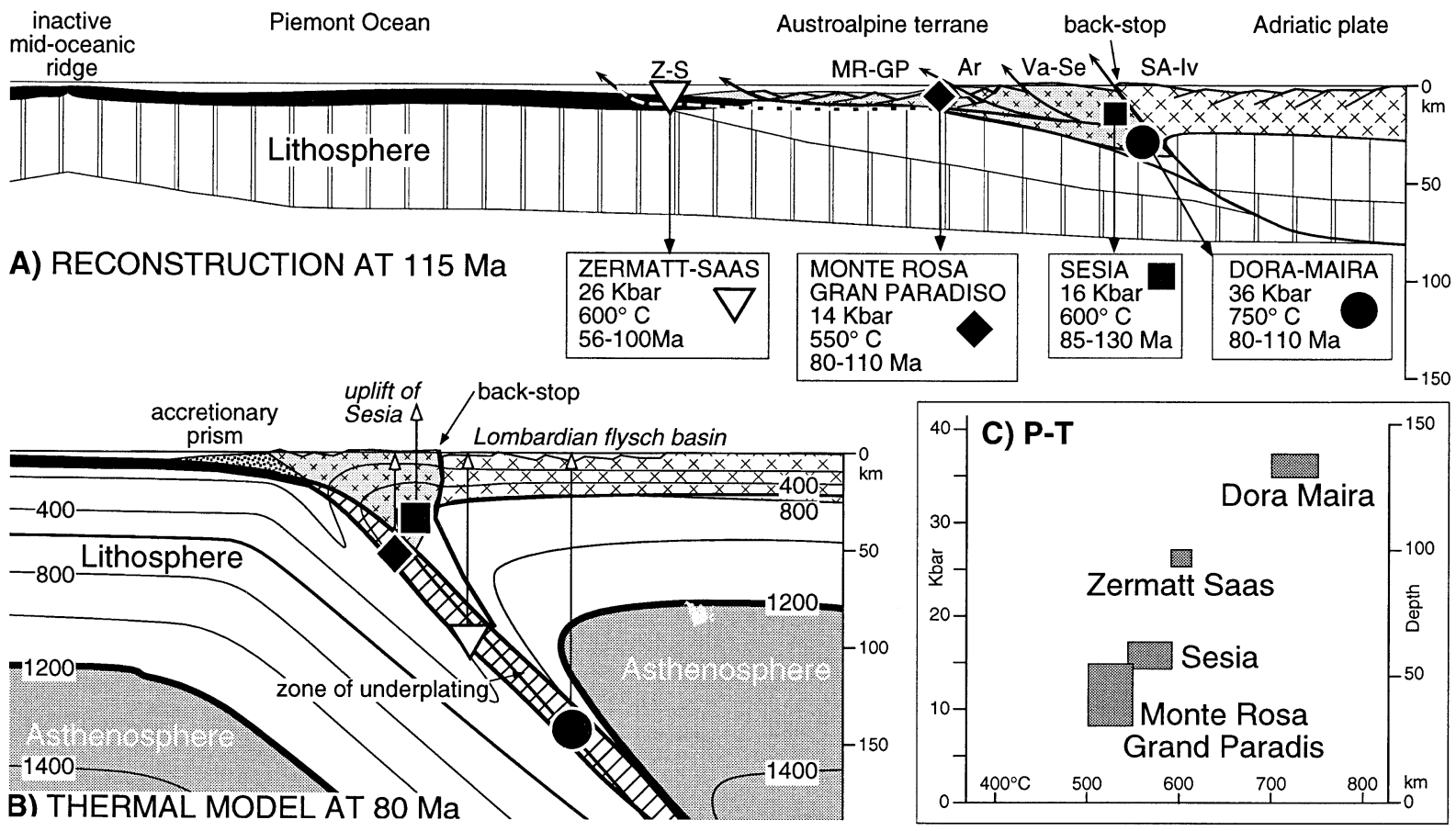

Fig. 15. (A) Reconstruction of the Alpine Tethys active margin in Aptian times: Ar= Arosa (Dent-Blanche); $M R-G P=$ Monte Rosa, Grand Paradis; $S A-I v=$ southern Alps-Ivrea; Va-Se = Valpelline (Dent-Blanche)-Sesia; Z-S = Zermatt-Saas ophiolite. (B) Thermal model in Campanian times with indication of depth reached by the eclogitic internal massifs. (C) Diagram of maximum P-T conditions for the western Alps eclogitic internal massifs. Dora Maira: Hunziker et al. (1989), Michard et al. (1993), Sharp et al. (1993); Zermatt-Saas: Hunziker et al. (1989), Reinecke (1991), Ballèvre and Merle (1993). Sesia: Hunziker et al. (1989), Ballèvre and Merle (1993), Venturini (1995); Monte Rosa, Grand Paradis: Monié (1985), Hunziker et al. (1989), Ballèvre and Merle (1993). 
A) PRESENT DAY CRUSTAL SCALE CROSS SECTION OF THE WESTERN ALPS ALONG THE NRP-20 DEEP SEISMIC TRAVERSE

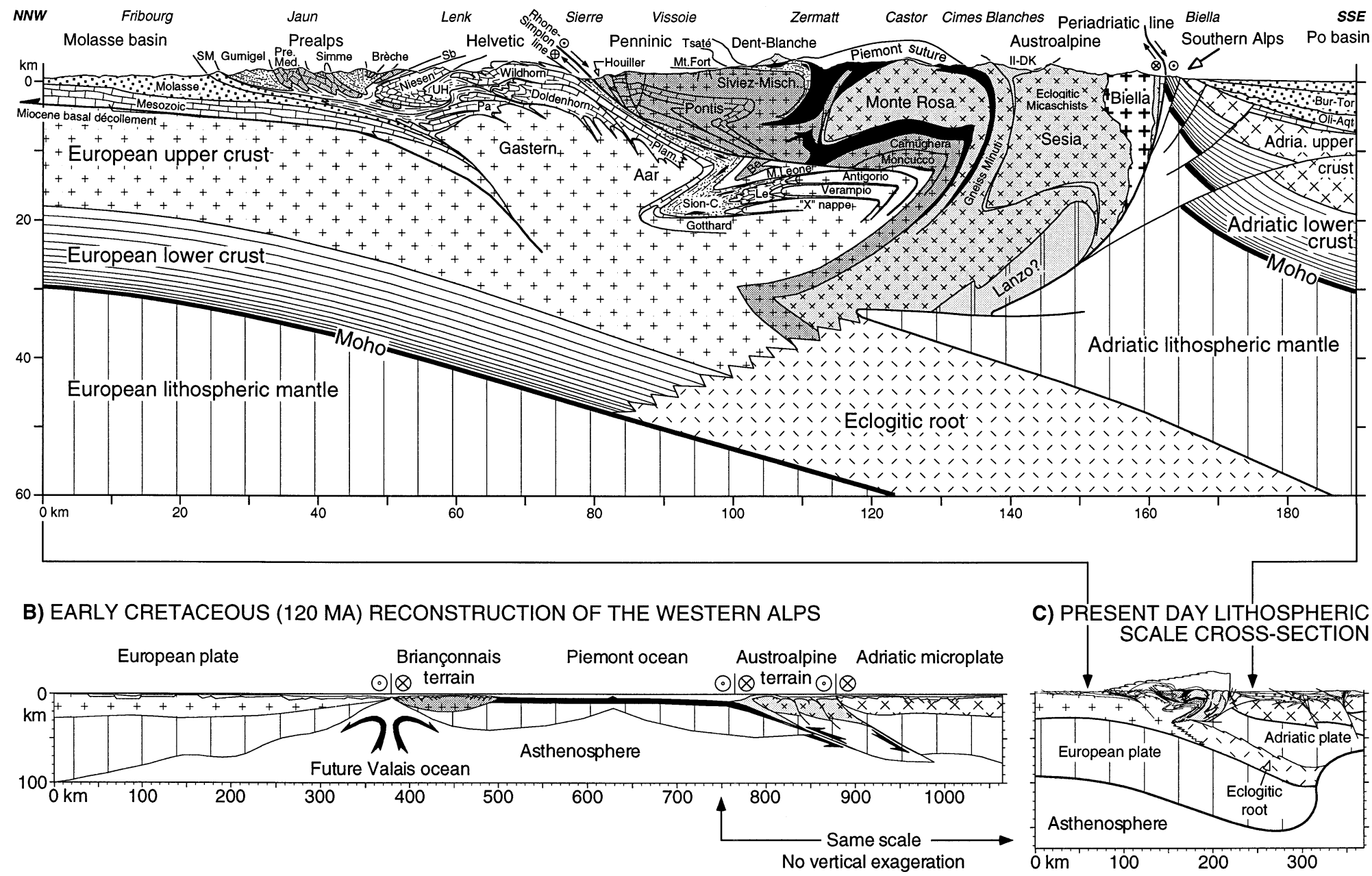

Fig. 16. Cross-section of the western Alps on a western Switzerland transect, and simplified palinspastic model, modified from Marchant (1993), Marchant and Stampfli (1997b). 
or its interpretation as evidence of a Cretaceous collision between Adria and the Briançonnais (e.g. Deville, 1993). Somehow this eoalpine subduction phase is needed as the subduction of the Piémont ocean lasted for approximately $80 \mathrm{Ma}$. Subduction most likely started in the Valanginian-Hauterivian due to the plate rearrangement at that time (Fig. 2) and subduction-related metamorphism just after that (e.g. HP-LT ages of the Sesia massif at $129 \mathrm{Ma}$, Oberhänsli et al., 1985). It was accompanied by major flysch input starting in the Cenomano-Turonian (Fig. 4) both in the Liguro-Piémont ocean (Caron et al., 1989; Gasinski et al., 1997) and Lombardian rim basin (e.g. Bichsel and Häring, 1981; Bernoulli and Winkler, 1990), related to increasing underplating. This implies that a subduction-related phase of deformation and metamorphism has to be present in the Alps as well as subduction-related mélanges where underplated elements of oceanic and continental origin are mixed together, either on their way down or during exhumation phases. Such a mélange is found in the upper Penninic nappes (Fig. 16) such as the Antrona (ophiolites), Monte Rosa (continental basement), Zermatt-Saas (ophiolites) and Sesia (continental basement) juxtaposition; all of these units present HP-LT assemblages and have ages between 52 (Bowtell et al., 1994) and 129 Ma (Oberhänsli et al., 1985).

Eclogitic eoalpine units also experienced more or less rapid uplift and changing $\mathrm{P}-\mathrm{T}$ conditions usually causing development of greenschist metamorphic facies and obliterating previous HP assemblages. In view of the changing geometry of the subduction zone (incorporation of exotic terranes, slab detachment) it could also be envisaged that some units went into HP-LT conditions in different stages, with only the last stage being recorded in terms of absolute dating. A stepwise burial of underplated units is merely the result of coupling and decoupling of both plates and depends largely on the buoyancy of the lower plate. The subduction of a mid-oceanic ridge or of lithospheric roots of terranes (like the Austroalpine) increases this buoyancy and increases the coupling. A unit formerly scrapped off in the prism can then be buried deeper and this process can be repeated several times. Tertiary ages do not exclude older eoalpine ages, both are compatible and necessary. Finally and to close this discussion on HP rocks, recent (Hunziker et al., 1992) and ongoing (J.C. Hunziker, pers. commun., 1998) measurements of fission track ages in the internal massifs retrace the exhumation processes of these rocks, ages as old as $49 \mathrm{Ma}$ have been found in Dora Maira and would confirm the eoalpine age of the UHP metamorphism.

\subsection{Ongoing subduction and collision}

The HP-LT metamorphism lasted until the incorporation of the Briançonnais into the prism but most likely after too, at least until the collision with the Helvetic margin as shown by the ages for the HP metamorphism in the Adula and Cima-Lunga nappes (37-44 Ma, Becker, 1993; 35 Ma, Gebauer, 1996) pertaining to the distal Helvetic margin. The subduction of the remnant Valais ocean is constrained by the ages of sedimentary rocks deposited in this region such as the Arblatsch flysch (Paleocene-Early Eocene, Ziegler, 1956; Eiermann, 1988), the inner Valais mélanges (Late Eocene-?Early Oligocene, M. Sartori, oral commun., 1998; Bagnoud et al., 1998) and the Zone Submédiane flysch, also of Paleocene to Early-Middle Eocene age. Actually the latter deposits are poorly dated and, as is the case for other Helvetic flysch, reworking of large foraminifers and even plankton is quite systematic and ages based on nummulites are maximum ages. The Sardona (east Switzerland, Lihou, 1996) and Meilleret flysch (west Switzerland, Homewood, 1974) of external Valais origin are as young as late-Middle Eocene (37 Ma).

These data point toward an ongoing process of obduction of the Briançonnais terrane between 45 and $40 \mathrm{Ma}$, then of the Valais sequences, followed by the obduction of distal Helvetic margin elements since 34-33 Ma. This is quite different from the Early Eocene subduction scenario developed by Pfiffner (1986) and still supported by Schmid et al. (1997) for the Valais and distal Helvetic units in eastern Switzerland.

As discussed above, closing of the Valais ocean had already started in Late Cretaceous during the rotation of Iberia from Turonian to Campanian. At a certain stage (during the Paleocene) the closure of the Valais ocean stopped and the Briançonnais was severed from the Iberian plate and somehow attached to the subducting European plate. This rearrangement of plates was accompanied by a relative lack 
of convergence between Africa-Adria and Europe at that time (Figs. 4 and 5). This is the Paleocene restoration phase of Trümpy (1980). One of the main outcomes is that the subducting European slab can be regarded since the Paleocene as a single slab carrying the lithospheric root of the Briançonnais terrane (Fig. 17).

Collision processes proper started as soon as the unthinned Helvetic basement entered the subduction zone. Decoupling of this basement left some room for continental subduction of the European plate (Marchant and Stampfli, 1997a) at least until the Pliocene. The overfed prism developed large-scale backthrusting and the Adriatic indenter and Insubric line turned into an A-subduction zone with important southward thrusting of the southern Alps (Figs. 16 and 18). Lateral westward escape of the over-thickened prism became possible as it advanced into the European plate leaving behind the Iberian plate. The prism was then affected by severe unroofing and E-

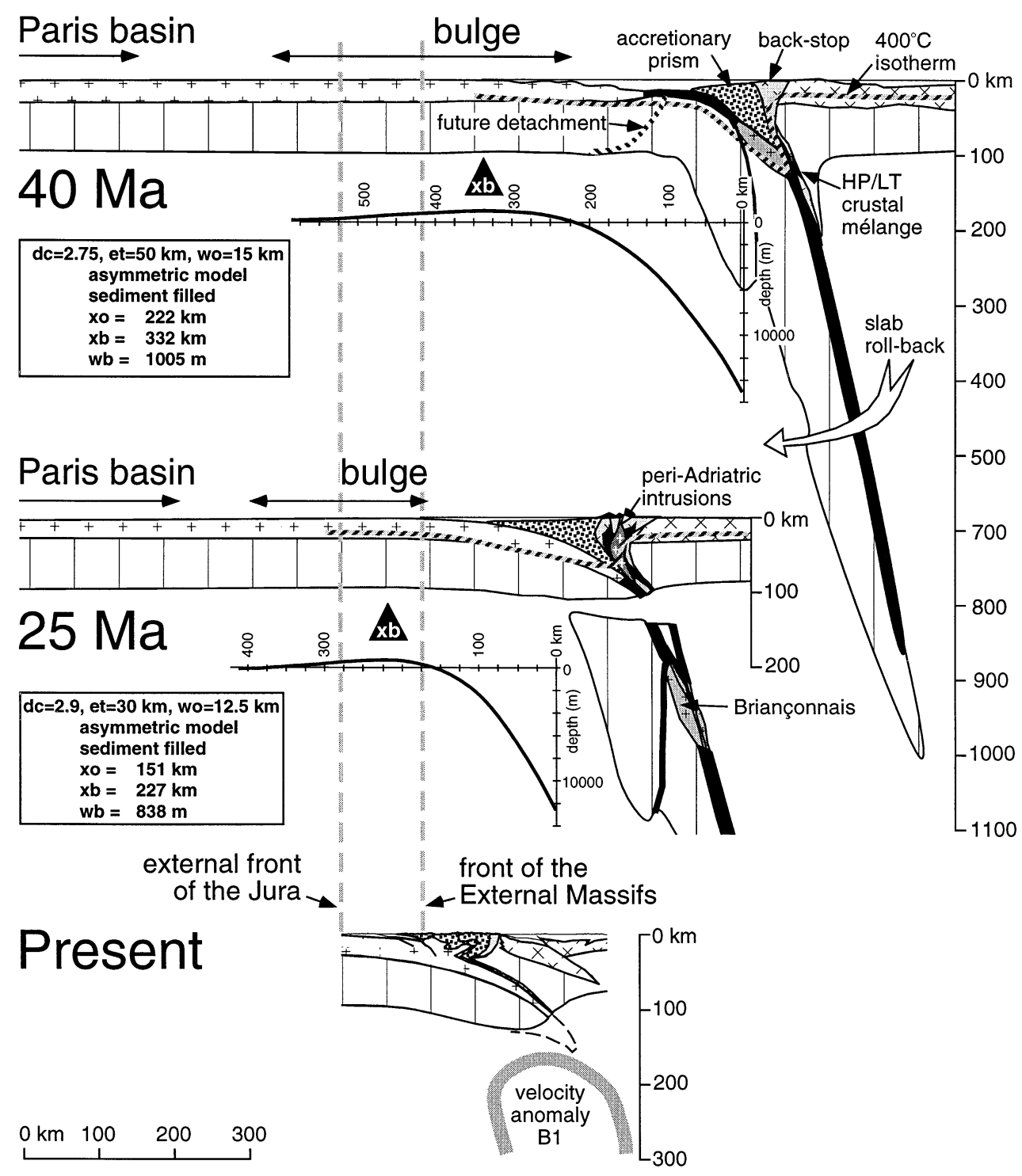

Fig. 17. Evolution of the Piémont subducting slab from Eocene to Present. Location of cross-sections in Fig. 18. 
W extension and the arc shape of the western Alps was formed by lateral escape of the upper plate; in this context HP units represent extensional core complexes. These events correspond to the D2 to D4 deformations of the eastern Briançonnais basement, straddling the $30 \mathrm{Ma}$ time boundary of the Bergell granitic intrusion.

As soon as the Helvetic basement entered the subduction zone, the increased buoyancy of the lower plate generated the detachment of the subducting slab (corresponding to the Piémont ocean, the Briançonnais lithospheric root and the Valais ocean; Fig. 17). The temporary unflexing of the lower plate generated a rapid transgression of deep water facies over the Helvetic domain around 34-35 Ma (Fig. 14), followed by the emplacement of the periAdriatic intrusions and related volcanism as found reworked in the Taveyannes flysch (Vuagnat, 1983).

In this context of changing geometries of the orogen, it is interesting to note the different structures of the flexural bulge. During Eocene times, before the slab detachment, the flexural bulge was quite large (Fig. 18) and the elastic thickness around $50 \mathrm{~km}$. After slab detachment the bulge became smaller as continental subduction took place. Modelling of the development of the Molassic foreland basin shows a decrease of the bulge and of the elastic thickness, possibly down to $25 \mathrm{~km}$ (Sinclair, 1996; Burkhard and Sommaruga, 1998). This changing behaviour can be explained by the fracturing of the European slab and the opening of the Rhine, Bresse and Limagnes grabens within the former bulge.

\subsection{How many slabs, how many subduction zones and the arc problem}

Figs. 1 and 2 show the probable location of the incipient subduction zone in the Alpine domain in the Early to Late Cretaceous. This subduction was initiated in the Early Jurassic by the eastward subduction of the Meliata ocean induced by the opening of the Alpine Tethys-Central Atlantic ocean (Fig. 1). The subduction zone followed the Meliata slab retreat, compensated eastward by the opening of the Vardar back-arc ocean. In the Early Cretaceous the subduction reached the western Austroalpine domain. The first phase of deformation affecting the southern Alpine Tethys margin in the Sesia area (130-120
Ma) has been related to the closure of the westernmost extension of the Meliata rift (Venturini, 1995). This closure in the Austroalpine domain produced HP rocks dated between 150 and 95 Ma (Thöni and Jagoutz, 1993) and HP detrital minerals are recycled in Turonian flysch in the eastern Alps (Winkler and Bernoulli, 1986). Early Cretaceous (Albian) primitive alkaline volcanism found in the Northern Calcareous Alps (Trommsdorff et al., 1990) preclude the existence of any subduction zone in the Austrian Penninic ocean at least before that time. Subduction of the Penninic oceanic domain might have started as late as the Campanian as shown by the rapid deepening of the Gosau basin at that time (Wagreich, 1993).

The Meliata slab produced a slab pull force into Europe. The subducting slab buoyancy might have become quite high due to remnants of continental crust attached to the slab (i.e. the Austro-Carpathian lithospheric roots); underplating was then the most probable type of subduction/obduction mechanism. The absence of an asthenospheric wedge between the two plates could then explain the absence of a magmatic arc along this subduction zone. Due to thick continental lithospheric roots, underplating of the subducting slab would have been more important in the Austroalpine Carpathian domain. This relatively high buoyancy and the absence of a separate subduction zone north of the Austro-Carpathian blocks could also explain the delayed slab break-off in the Carpathians; a break-off which is still occurring at the present. Tomographic images seem to prove such a changing geometry between the subduction zone around Adria and the Austro-Carpathian area (Spakman et al., 1993). High coupling of the two plates also explains the widespread inversion processes affecting most of western Europe since the Late Cretaceous, long before the final continentcontinent collision.

In the Turonian, the Alpine Tethys oceanic floor and its thin southern margin started subducting, inducing the HP metamorphism of the future internal massifs. The opening of the North Atlantic and Biscay oceans at this time induced a rapid rotation of Africa. This corresponds to the separation of the Austroalpine from Adria (Fig. 2) and the lateral escape of terranes (e.g. Trans-Danubian, Tizia terranes). The subduction zone first located in the 


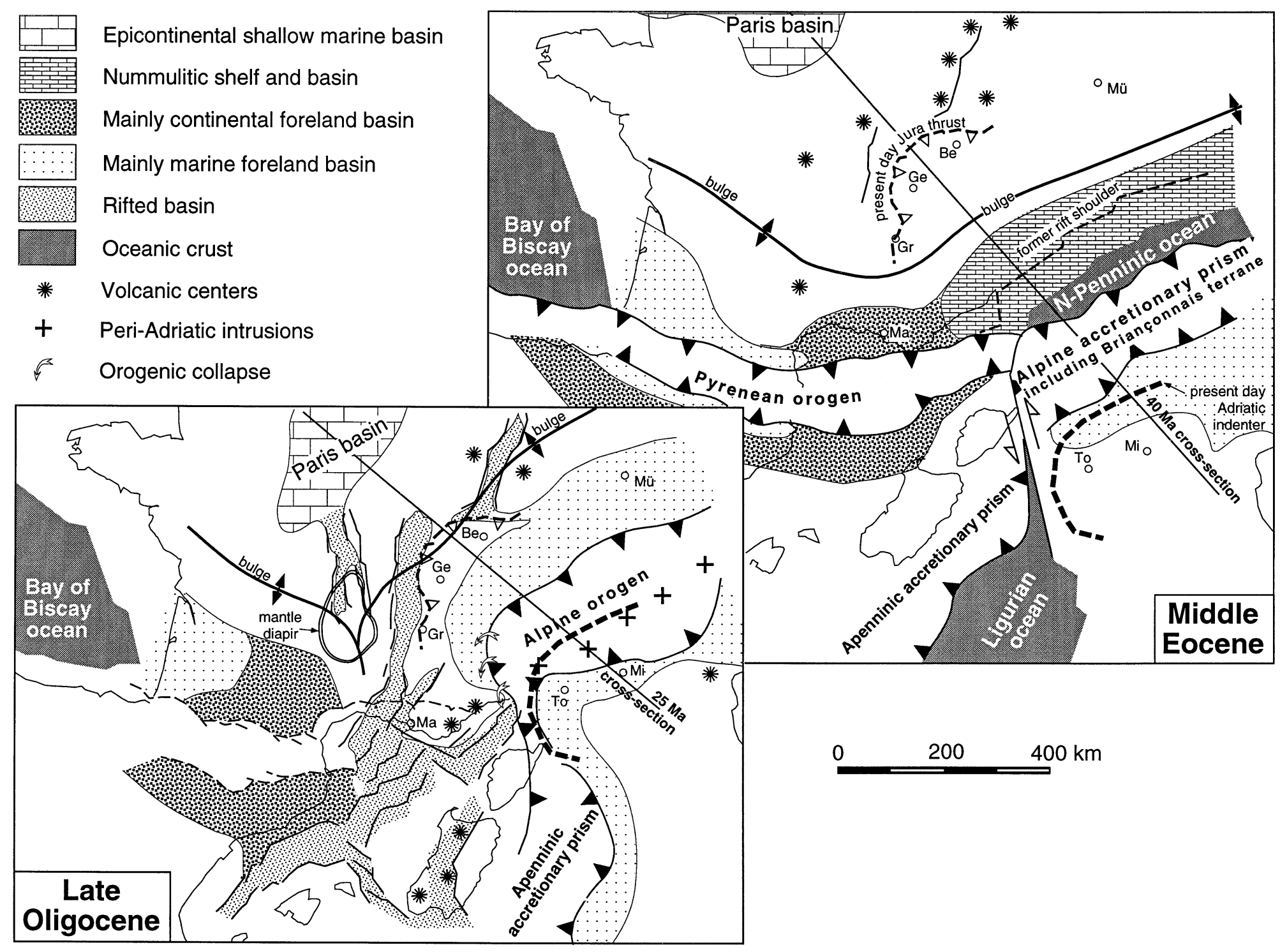

Fig. 18. Palaeogeographic-palaeotectonic maps of the Alpine-Pyrenean region in the Middle Eocene and Late Oligocene. 
Meliata ocean moved into the Alpine Tethys and Valais ocean, then after the Paleocene, it cut between the Briançonnais and the Iberian plate, propagating up to the Biscay ocean southern margin (Figs. 2 and 18). The plate limit westward was the mid-oceanic ridge of the northern Atlantic (Ziegler, 1988).

The Early to Middle Eocene Pyrenean collision induced a north-dipping subduction zone to develop south of the Iberian plate, grading into the formation of the Apenninic accretionary prism in Tertiary times (Fig. 18). A similar collision, affecting the south-dipping Alpine subduction zone, also occurred in the east where the Vardar ocean developed a north-dipping subduction zone under the Moesian platform in the Late Cretaceous (Fig. 2), accompanied by an active volcanic arc in these regions and slab detachment in the Eocene-Oligocene (Yanev and Bardintzeff, 1997). In a present-day configuration (Fig. 6), the N-vergent Alpine-Carpathian belt is relatively isolated from the S-vergent MaghrebidesApenninic-Dinaro-Hellenides younger segment, following a rather complicated Tertiary history of closing and opening oceans in the Mediterranean region.

\section{Conclusions}

Plate reconstruction as well as analysis of structural, stratigraphic and absolute age data sets for the Briançonnais and surrounding domains allows the timing of subduction/obduction processes of the western and eastern Alps to be constrained. The incorporation of the Briançonnais exotic terrane in the Piémont-Penninic accretionary prism did not take place before $45 \mathrm{Ma}$. Older, more internal HP-LT metamorphic units (internal massifs: Monte Rosa, Grand Paradis, Dora Maira) are therefore not of Briançonnais origin, they belonged to the Alpine Tethys southern margin. This margin became an active margin during the Cretaceous, the initial accretionary prism being represented by the lower Austroalpine units (internal massifs, Sesia, Dent-Blanche), some of them developing eclogitic metamorphic facies, and ophiolite-rich mélanges (Tsaté nappe). Subsequently, the accretionary prism accreted mainly Cretaceous oceanic sequences from the Alpine Tethys found nowadays in the Nappe Supérieure of the Préalpes (Gets and Simme nappes). The incorpo- ration of basement slivers and sedimentary covers from the Briançonnais domain took place from the Lutetian (in the east) to Priabonian (in the west). Following this, elements from the Valais ocean were mainly underplated, as were elements from the distal Helvetic margin which were locally affected by HP-LT metamorphism, although most of the oceanic/continental substratum of these domains was subducted. Collision processes started when the unthinned Helvetic crust started subducting in late-Early Oligocene. Detachment and obduction of large parts of the Helvetic basement allowed further subduction together with a reorganisation of the prism due to the Piémont slab detachment around the Eocene-Oligocene boundary.

From Paleocene to Oligocene a single subduction zone is envisaged as being responsible for the formation of the Pyrenean, Alpine, Austroalpine and Carpathian fold belt, a subduction zone which jumped from one ocean to the other in time: the Meliata ocean in the Jurassic, the Alpine Tethys in the Early Cretaceous and the Pyrenees-Biscay ocean until the Middle Eocene. This mainly southdirected subduction was replaced then by a mainly north-directed subduction which gave birth to the Maghrebides, Apennines, Dinarides and Hellenides and which is still active today.

\section{Acknowledgements}

We want to thank here our Alpine geologists colleagues who shared with us their sometimes contradicting opinions and data, and more particularly M. Sartori, M. Jaboyedoff, M. Cosca and J. Hunziker. W. Frish and T. Dumont reviewed this paper and we thank them for improving its readability. Part of this research was supported by the Swiss National Fund grant 20-49114.96.

\section{References}

Ackermann, A., 1986. Le flysch de la nappe du Niesen. Eclogae Geol. Helv. 79, 641-684.

Ackermann, T., 1979. Etude sédimentologique comparatrice du Mésozoïque ultrahelvétique de la Tour d'Anzeinde. Unpubl. Diplôme, Fribourg.

Allen, P.A., Crampton, S.L., Sinclair, H.D., 1991. The incep- 
tion and early evolution of the North Alpine Foreland Basin, Switzerland. Basin Res. 3, 143-163.

Antoine, P., 1971. La zone des brèches de Tarentaise entre Bourg-Saint-Maurice (vallée de l'Isère) et la frontière italosuisse. Thèse d'Etat, Univ. Grenoble.

Badoux, H., 1963. Les unités ultrahelvétiques de la Zone des Cols. Eclogae Geol. Helv. 56, 1-13.

Badoux, H., 1965. Les relations de l'Ultrahelvétique et des Préalpes médianes dans la vallée de la Grande Eau. Eclogae Geol. Helv. 58, 11-16.

Badoux, H., Homewood, P., 1978. Le soubassement de la nappe du Niesen dans la région du Sepey (Alpes vaudoises). Bull. Soc. Vaudoise Sci. Nat. 74, 15-23.

Badoux, H., Mercanton, C.H., 1962. Essai sur l'évolution tectonique des Préalpes médianes du Chablais. Eclogae Geol. Helv. 55, 135-188.

Badoux, H., Norbert, J., 1952. Une fenêtre d'Ultrahelvétique dans les Préalpes médianes du Chablais (région de la Vacheresse). Bull. Soc. Vaudoise Sci. Nat. 65, 1-5.

Bagnoud, A., Wernli, R., Sartori, M., 1998. Découverte de foraminifères planctoniques dans la zone de Sion-Courmayeur à Sion. Eclogae Geol. Helv., submitted.

Ballèvre, M., Merle, O., 1993. The Combin fault: compressional reactivation of a Late Cretaceous-early Tertiary detachment fault in the western Alps. Schweiz. Mineral. Petrogr. Mitt. 73, 205-227.

Baltzer, D., 1989. Petrographie, Geochemie, Tektonik, Metamorphose und Geochronologie im nordwestlichen Teil der Suretta Decke. Unpubl. Liz. arbeit, Univ. Bern.

Barféty, J.C., Tricard, P., Jeudy de Grissac, C., 1992. La quatrième écaille près de Briançon (Alpes Françaises); un olistostrome précurseur de l'orgénèse pennique éocène. C. R. Acad. Sci. Paris 314 (II), 71-76.

Baud, A., 1972. Observations et hypothèses sur la géologie de la partie radicale des Préalpes médianes. Eclogae Geol. Helv. 65, 43-55.

Baud, A., 1987. Stratigraphie et sédimentologie des calcaires de Saint-Triphon (Trias, Préalpes, Suisse et France). Mém. Géol. (Lausanne) 1, 1-322.

Baud, A., Masson, H., 1975. Preuves d'une tectonique de distension dans le domaine briançonnais; failles conjugées et paléokarst à Saint-Triphon (Préalpes médianes, Suisse). Eclogae Geol. Helv. 68, 131-145.

Baud, A., Septfontaine, M., 1980. Présentation d'un profil palinspastique de la nappe des Préalpes médianes en Suisse occidentale. Eclogae Geol. Helv. 73, 651-660.

Baud, A., Masson, H., Septfontaine, M., 1979. Karsts et paléotectonique jurassiques du domaine briançonnais des Préalpes. In: Symp. Sédimentation jurassique ouest Europe. Assoc. Sédimentol. Fr. Publ. Spec., Paris, pp. 441-452.

Baud, A., Heinz, R., Septfontaine, M., 1989. Compte rendu de l'excursion de la Société Géologique Suisse dans les Préalpes, du 2 au 4 octobre, 1988. Eclogae Geol. Helv. 82, 359-377.

Baudin, Th., Marquer, D., 1993. Histoire P-T-déformation du socle et de la couverture de la nappe de Tambo. Utilisation du géobaromètre phengitique (Alpes centrales suisses). Schweiz. Mineral. Petrogr. Mitt. 73, 293-307.
Baudin, Th., Marquer, D., Persoz, F., 1991. New lithological and structural results in the Tambo nappe, Central Alps, Switzerland. Terra Abstr. 3 (1), 222.

Baudin, Th., Marquer, D., Persoz, F., 1993. Basement-cover relationships in the Tambo nappe (Central Alps, Switzerland); geometry, structures and kinematics. J. Struct. Geol. $15(3 / 5)$, 543-553.

Baudin, Th., Marquer, D., Barfety, J.C., Kerckhove, C., Persoz, F., 1995. A new stratigraphical interpretation of the Mesozoic cover of the Tambo and Suretta nappes. Evidence for early thin-skinned tectonics. C. R. Acad. Sci. Paris, 321, IIa, pp. 401-408.

Becker, H., 1993. Garnet peridotite and eclogite Sm-Nd mineral ages from the Lepontine dome (Swiss Alps). New evidence for Eocene high-pressure metamorphism in the central Alps. Geology 21, 599-602.

Bernoulli, D., Winkler, W., 1990. Heavy mineral assemblages from Upper Cretaceous South and Austro-Alpine flysch sequences (N-Italy and S-Switzerland). Source terranes and paleotectonic implications. Eclogae Geol. Helv. 83, 287-310.

Bernoulli, D., Caron, C., Homewood, P., Kälin, O., van Stuijvenberg, J., 1979. Evolution of continental margins of the Alps. Schweiz. Mineral. Petrogr. Mitt. 59, 165-170.

Bertotti, G., Picotti, V., Bernoulli, D., Castellarin, A., 1993. From rifting to drifting. Tectonic evolution of the South-Alpine upper-crust from the Triassic to the Early Cretaceous. Sediment. Geol. 86, 53-76.

Bichsel, M., Häring, M.O., 1981. Facies evolution of late Cretaceous flysch in Lombardy (Northern Italy). Eclogae Geol. Helv. 74, 383-420.

Biino, G., Marquer, D., Nussbaum, Ch., 1997. Alpine and PreAlpine subduction events in polycyclic basements of the Swiss Alps. Geology 25 (8), 751-754.

Bill, M., Bussy, F., Cosca, M., Masson, H., Hunziker, J.C., 1997. High precision $\mathrm{U}-\mathrm{Pb}$ and ${ }^{40} \mathrm{Ar} /{ }^{39} \mathrm{Ar}$ dating of an Alpine ophiolite (Gets nappe, French Alps). Eclogae Geol. Helv. 90, 43-54.

Blanc, B.L., 1965. Zur Geologie zwischen Madesimo und Chiavenna (Provinz Sondrio Italien). Mitt. Geol. Inst. ETH Univ. Zürich 37.

Boller, K., 1963. Stratigraphische und Mikropaläontologische Untersuchungen im Neocom der Klippendecke (östlich der Rhône). Eclogae Geol. Helv. 56, 15-102.

Borel, G., 1995. Préalpes médianes. Courbes de subsidence et implications géodynamiques. Bull. Soc. Vaudoise Sci. Nat. 83, 293-315.

Borel, G., 1998. Dynamique de l'extension mésozoique du domaine briançonnais. Les Préalpes médianes au Lias. Thèse, Univ. Lausanne.

Bowtell, S.A., Cliff, R.A., Barnicoat, A.C., 1994. Sm-Nd isotopic evidence on the age of eclogitization in the Zermatt-Saas ophiolite. J. Metamorph. Geol. 12, 187-196.

Bradbury, H.J., Nolen-Hoeksema, R.C., 1985. The Lepontine Alps as an evolving metamorphic core complex during A-Type subduction. Evidence from heat flow, mineral cooling ages, and tectonic modeling. Tectonophysics 4, 187-211.

Burkhard, M., 1988. L'Helvétique de la bordure occidentale 
du Massif de l'Aar (évolution tectonique et métamorphique). Eclogae Geol. Helv. 81, 63-114.

Burkhard, M., Sommaruga, A., 1998. Evolution of the Swiss Molasse basin: structural relations with the Alps and the Jura belt. Geol. Soc. London Spec. Publ., in press.

Burri, M., 1958. La zone de Sion-Courmayeur au nord du Rhône. Matér. Carte Géol. Suisse N.S. 105, 45 pp.

Cannic, S., 1996. L'évolution magmatique et tectono-métamorphique du substratum du domaine Valaisan (complexe du Versoyen, Alpes occidentales) implications dans l'histoire alpine. Thèse, Univ. Joseph-Fourier, Grenoble, 209 pp.

Cannic, S., Lardeaux, J.-M., Mugnier, J.-L., Hernandez, J., 1996. Tectono-metamorphic evolution of the Roignais-Versoyen Unit (Valaisan domain, France). Eclogae Geol. Helv. 89, 321-343.

Caron, C., 1972. La nappe supérieure de Préalpes. Subdivisions et principaux caractères du sommet de l'édifice préalpin. Eclogae Geol. Helv. 65, 47-73.

Caron, C., 1973. Survol géologique des Alpes occidentales. Bull. Soc. Frib. Sci. Nat. 62, 73-81.

Caron, C., Homewood, P., Morel, R., van Stuijvenberg, J., 1980a. Témoins de la Nappe du Gurnigel sur les Préalpes Médianes. Une confirmation de son origine ultrabriançonnaise. Bull. Soc. Frib. Sci. Nat. 69, 64-79.

Caron, C., Homewood, P., van Stuijvenberg, J., 1980b. Flysch and molasse of western and central Switzerland. In: Trümpy, R. (Ed.), Geology of Switzerland, a Guidebook, Part B, Geological Excursions. Wepf, Basel, pp. 274-278.

Caron, C., Homewood, P., Wildi, W., 1989. The original Swiss flysch. A reappraisal of the type deposits in the Swiss Prealps. Earth-Sci. Rev. 26, 1-45.

Caron, M., Dupasquier, C., 1989. Litho- et biostratigraphie des dépôts du 'Crétacé moyen' dans les Préalpes Médianes. Geobios, Mém. Spéc. 11, 49-58.

Channell, J.E.T., 1992. Paleomagnetic data from Umbria (Italy). Implications for the rotation of Adria and Mesozoic apparent polar wander paths. Tectonophysics 216, 365-378.

Channell, J.E.T., 1996. Paleomagnetism and paleogeography of Adria. Geol. Soc. London Spec. Publ. 105, 119-132.

Channell, J.E.T., Doglioni, C., 1994. Early Triassic paleomagnetic data from the Dolomites (Italy). Tectonics 13, 157-166.

Channell, J.E.T., Kozur, H.W., 1997. How many oceans? Meliata, Vardar and Pindos oceans in Mesozoic Alpine paleogeography. Geology 25, 183-186.

Channell, J.E.T., Doglioni, C., Stoner, J.S., 1992. Jurassic and Cretaceous paleomagnetic data from the Southern Alps (Italy). Tectonics 11, 811-822.

Charollais, J., Atrops, F., Busnardo, R., Fontannaz, L., Kindler, P., Wernli, R., 1993. Précisions stratigraphiques sur les Collines du Faucigny, Préalpes ultrahevétique de haute Savoie (France). Eclogae Geol. Helv. 86, 397-414.

Chaulieu, P., 1992. La sédimentation détritique sur la marge nord-téthysienne témoin de l'évolution géodynamique des Alpes occidentales. Thèse, Grenoble, 394 pp.

Cosca, M.A., Hunziker, J.C., Huon, S., Masson, H., 1992. Radiometric age constraints on mineral growth, metamorphism, and tectonism of the Gummfluh klippe, Briançonnais domain of the Préalpes, Switzerland. Contrib. Mineral. Petrol. 112, 439-449.

Coward, M., Dietrich, D., 1989. Alpine tectonics - an overview. In: Coward, M.P., Dietrich, D., Park, R.G. (Eds.), Alpine Tectonics. Geol. Soc. London Spec. Publ. 45, 1-29.

Dal Piaz, G.V., Lombardo, B., 1986. Early Alpine eclogite metamorphism in the Penninic Monte Rosa-Gran Paradiso basement nappes of the northwestern Alps. Geol. Soc. Am. Mem. 164, 249-265.

Davidson, C., Rosenberg, C., 1996. Synmagmatic folding of the base of the Bergell pluton, Central Alps; evidence from the western contact. Tectonophysics 265, 213-238.

Davies, J.H., von Blanckenburg, F., 1995. Slab breakoff: a model of lithosphere detachment and its test in the magmatism and deformation of collisional orogens. Earth Planet. Sci. Lett. $129,85-102$

Debrand-Passard, S., Courbouleix, S., 1984. Synthèse géologique du S-E de la France. Mém. BRGM 126, 234 pp.

De Coulon, S., 1990. Géologie et minéralogie de l'écaille de l'Amsalgrat. Diploma, Lausanne (unpubl.).

De Jonge, M.R., Wortel, M.J.R., Spakman, W., 1994. Regional scale tectonic evolution and the seismic velocity structure of the lithosphere and upper mantle. The Mediterranean region. J. Geophys. Res. 99, 12091-12108.

Dercourt, J., Zonenshain, L.P., Ricou, L.C., 1985. Présentation des 9 cartes paléogéographiques au 1/20000 000 s'étendant de l'Atlantique au Pamir pour la période du Lias à l'Actuel. Bull. Soc. Géol. Fr. 8, 637-652.

Dercourt, J., Ricou, L.E., Vrielinck, B., 1993. Atlas Tethys, Paleoenvironmental Maps. Gauthier-Villars, Paris, 307 pp.

Deville, E., 1987. Etude géologique en Vanoise orientale (Alpes occidentales françaises, Savoie). De la naissance à la structuration d'un secteur de la paléomarge européenne et de l'ocèan téthysien. Aspects stratigraphiques, pétrographiques et tectoniques. Thèse 8 , Univ. de Savoie.

Deville, E., 1993. Tectonique précoce crétacée et orogénèse tertiaire dans les schistes lustrés des Alpes occidentales. Exemple de la transversale de la Vanoise. Geodin. Acta 6, 19-37.

Deville, E., Fudral, S., Lagabrielle, Y., Marthaler, M., Sartori, M., 1992. From oceanic closure to continental collision. A synthesis of the schistes lustrés metamorphic complex of the Western Alps. Geol. Soc. Am. Bull. 104, 127-139.

Duchêne, S., Blichert-Toft, J., Luais, B., Telouk, P., Lardeaux, J.-M., Albarède, F., 1997a. The Lu-Hf dating of garnets and the ages of the Alpine high-pressure metamorphism. Nature 387, 586-589.

Duchêne, S., Lardeaux, J.-M., Albarède, F., Blichert-Toft, J., Luais, B., Télouk, P., 1997b. Diachronous Lu-Hf ages of high-pressure rocks in the western Alps. In: 3rd Workshop on Alpine Geological Studies. Biella 4, 40-41.

Dürr, S.B., Ring, U., Frisch, W., 1993. Geochemistry and geodynamic significance of North Penninic ophiolites from the central Alps. Schweiz. Mineral. Petrogr. Mitt. 73, 407-419.

Eiermann, D., 1988. Zur Stellung des Martegnas-Zuges. Eclogae Geol. Helv. 81, 259-272.

Ellenberger, F., 1950. Sur les affinitées briançonnaises du Trias à 
faciès des Préalpes médianes suisses. C. R. Soc. Géol. Fr. 4, 55-57.

Ellenberger, F., 1952. Sur l'extension des faciès briançonnais en Suisse, dans les Préalpes médianes et les Pennides. Eclogae Geol. Helv. 45, 285-286.

Escher, A., Hunziker, J., Masson, H., Sartori, M., Steck, A., 1997. Geologic framework and structural evolution of the western Swiss-Italian Alps. In: Pfiffner, O.A., Lehner, P., Heitzman, P.Z., Mueller, S., Steck, A. (Eds.), Deep Structure of the Swiss Alps - Results from NRP 20. Birkhäuser AG, Basel, pp. 205-222.

Favre, P., Stampfli, G.M., 1992. From rifting to passive margin. The Red Sea, the central Atlantic and the Alpine Tethys as examples. Tectonophysics 215, 69-97.

Frank, W., 1987. Evolution of the Austroalpine elements in the Cretaceous. In: Flügel, H., Faupl, P. (Eds.), Geodynamics of the Eastern Alps. Deuticke, Vienna, pp. 379-406.

Frei, W., Heitzmann, P., Lehner, P., Muller, St. Olivier, R., Pfiffner, A., Steck, A., Valasek, P., 1989. Geotraverses across the Swiss Alps. Nature 340, 544-548.

Frisch, W., 1979. Tectonic progradation and plate tectonic evolution of the Alps. Tectonophysics 60, 121-139.

Froitzheim, N., Manatschal, G., 1996. Kinematics of Jurassic rifting, mantle exhumation, and passive-margin formation in the Austroalpine and Penninic nappes (Eastern Switzerland) Geol. Soc. Am. Bull. 108 (9), 1120-1133.

Froitzheim, N., Schmid, S., Conti, P., 1994. Repeated change from crustal shortening to orogen-parallel extension in the Austroalpine units of Graubünden. Eclogae Geol. Helv. 87 (2), 559-612.

Froitzheim, N., Conti, P., van Daalen, M., 1997. Late Cretaceous, synorogenic low-angle normal faulting along the Schlinig fault (Switzerland, Italy, Austria) and its significance for the tectonics of the eastern Alps. Tectonophysics 280, 267-293.

Fudral, S., 1996. Etude géologique de la suture téthysienne dans les Alpes franco-italiennes nord-occidentales de la Doire Ripaire (Italie) à la région de Bourg-Sanit-Maurice (France). Thèse d'Etat, Savoie, 284 pp.

Furrer, U., 1979. Stratigraphie des Doggers der östlichen Préalpes (Bern). Eclogae Geol. Helv. 72, 623-672.

Furrer, U., Septfontaine, M., 1977. Nouvelles données biostratigraphiques dans le Dogger à faciès briançonnais des Préalpes médianes romandes (Suisse). Eclogae Geol. Helv. 70, 717737.

Gansser, A., 1937. Der Nordrand der Tambodecke. Schweiz. Mineral. Petrogr. Mitt. 17 (2), 291-523.

Gasinski, A., Slaczca, A., Winkler, W., 1997. Tectono-sedimentary evolution of the Upper Prealpine nappe (Switzerland and France): nappe formation by late Cretaceous-Paleogene accretion. Geodin. Acta 10, 137-157.

Gebauer, D., 1996. A P-T-t path for an (ultra?-) high-pressure ultramafic/mafic rock-association and its felsic country-rocks based on SHRIMP-dating of magmatic and metamorphic zircon domains. Example. Alpe Arami (central Swiss Alps). In: Basu, A., Hart, S. (Eds.), Earth Processes. Reading the Isotopic Code. Am. Geophys. Union 95, 307-329.

Gély, J.-P., 1989. Stratigraphie, tectonique et métamorphisme comparés de part et d'autre du front pennique en Tarentaise. Univ. de Savoie, Chambéry, 343 pp.

Goffé, B., Oberhänsli, R., 1992. Ferro- and magnesiocarpholite in the 'Bündnerschiefer' of the eastern Central Alps (Grisons and Engadine window). Eur. J. Mineral. 4, 835-838.

Gradstein, F.M., Agterberg, F.P., Ogg, J.G., Hardenbol, J., Van Veen, P., Thierry, J., Huang, Z., 1995. A Triassic, Jurassic and Cretaceous time scale. In: Berggren, W.A., Kent, D.V., Aubry, M.P., Hardenbol, J. (Eds.), Geochronology, Time Scales and Global Stratigraphic Correlation. Soc. Econ. Paleontol. Mineral. Spec. Publ. 54, 95-126.

Grünenfelder, M., 1956. Petrographie des Roffnakristallins in Mittelbünden und seine Eisenvererzung. Beitr. Geol. Karte Schweiz 35, 57 pp.

Gübeli, A.A., 1982. Stratigraphische und sedimentologische Untersuchung der detritischen Unterkreide-Serien des zentralen Rif (Marokko). Ph.D. Thesis, Univ. Zürich.

Guillaume, M., 1986. Révision stratigraphique des Couches Rouges de la nappe des Préalpes Médianes Romandes. Ph.D. Thesis 910, Univ. Fribourg, 154 pp.

Gulson, B.L., 1973. Age relations in the Bergell region of the southeast Swiss Alps - with some geochemical comparisons. Eclog. Geol. Helv. 66 (2), 293-313.

Hable, R., 1997. Biostratigraphie, Sedimentologie und paläogeographische Entwicklung der Préalpes Médianes des Chablais (Haute Savoie) vom Apt bis Unter-Eözan. Thesis 1166, Univ. Fribourg, 324 pp.

Hanson, G.N., Grünenfelder, M., Soptraynova, G., 1969. The geochronology of a recrystallised tectonite in Switzerland the Roffna gneiss. Earth Planet. Sci. Lett. 5, 413-422.

Heinrich, C.A., 1982. Kyanite-eclogite to amphibolite facies evolution of hydrous mafic and pelitic rocks, Adula nappe, Central Alps. Contrib. Mineral. Petrol. 81, 30-38.

Heinz, R.A., 1985. Mikrofazielle Untersuchungen des Massifkalks (Malm) der Préalpes Médianes im Querschnitt Moléson Ruebli/Gummfluh. Ph.D. Thesis 209, Univ. Bern.

Heinz, R., Isenschmid, C., 1988. Mikrofazielle und stratigrafische Untersuchungen im Massifkalk (Malm) der Préalpes Médianes. Eclogae Geol. Helv. 81, 1-62.

Heitzmann, P., 1987. Evidence of late Oligocene/early Miocene backthrusting in the central alpine 'root zone'. Geodin. Acta 1, 183-192.

Herb, R., 1988. Eocene Paläogeographie und Paläotektonik des Helvetikums. Eclogae Geol. Helv. 81, 611-657.

Hesse, R., 1974. Long-distance continuity of turbidites. Possible evidence for an early Cretaceous trench abyssal plain in the East Alps. Geol. Soc. Am. Bull. 85, 859-870.

Homewood, P., 1974. Le flysch du Meilleret (Préalpes romandes) et ses relations avec les unités l'encadrant. Eclogae Geol. Helv. 67, 349-401.

Homewood, P., Caron, C., 1982. Flysch of the Western Alps. In: Hsü, K.J. (Ed.), Mountain Building Processes. Academic Press, New York, pp. 157-168.

Huber, R., Marquer, D., 1996. Tertiary deformations and kinematics of the southern part of the Tambo and Suretta nappes (Val Bregeglia, Eastern Swiss Alps). Schweiz. Mineral. Petrogr. Mitt. 76 (3), 383-397. 
Hunziker, J., Desmons, J., Martinotti, G., 1989. Alpine thermal evolution in the central and western Alps. In: Coward, M.P., Dietrich, D., Park, R.G. (Eds.), Alpine Tectonics. Geol. Soc. London Spec. Publ. 45, 353-368.

Hunziker, J.C., Desmons, J., Hurford, A.J., 1992. Thirty-two years of geochronological work in the Central and Western Alps. A review on seven maps. Mém. Géol. (Lausanne) 13, 59 pp.

Huon, S., Kübler, B., Hunziker, J., 1988. Identifications de mélanges de micas blancs par diffraction des rayons X. Application à des séries carbonatées faiblement métamorphiques. Schweiz. Mineral. Petrogr. Mitt. 68, 185-202.

Hurford, A.J., 1986. cooling and uplift patterns in the Lepontine Alps south-central Switzerland and an age of vertical movement on the Insubric fault line. Contrib. Mineral. Petrol. 92 (4), 413-427.

Hurford, A., Flisch, M., Jäger, E., 1989. Unravelling the thermotectonic evolution of the Alps. A contribution from fission track analysis and mica dating. In: Coward, M., Dietrich, D., Park, R. (Eds.), Alpine Tectonics. Geol. Soc. London Spec. Publ. 45, 369-398.

Hürlimann, A., Besson-Hürlimann, A., Masson, H., 1996. Stratigraphie et tectonique de la partie orientale de l'écaille de la Gummfluh (Domaine Briançonnais des Préalpes). Mém. Géol. (Lausanne) 28, 132.

Huyghes, P., Mugnier, J.-L., 1995. A comparison of inverted basins of the Southern North Sea and inverted structures of the external Alps. In: Buchanan, J.G., Buchanan, P.G. (Eds.), Basin Inversion. Geol. Soc. London Spec. Publ. 88, 339-353.

Isenschmid, C., 1983. Der Malm im Mittelabschnitt der Préalpes médianes zwischen Thuner- und Genfersee. Ph.D. Thesis, Univ. Bern.

Jaboyedoff, M., Thélin, P., 1995. New data on low metamorphism in the Briançonnais domain of the Préalpes, Western Switzerland. Eur. J. Mineral. 8, 577-592.

Jäger, E., Niggli, E., Wenk, E., 1967. Altersbestimmungen an Glimmer der Zentralalpen. Beitr. Geol. Karte Schweiz, N.F.L. 134, 1-67.

Jaillard, E., 1988. Une image paléogéographique de la Vanoise briançonnaise (Alpes françaises). Eclogae Geol. Helv. 81, 553-566.

Jeanbourquin, P., 1991a. L'Ultrahelvétique à Derborence (Valais, Suisse). Bull. Murithienne, Soc. Valais. Sci. Nat. 109, 65-95.

Jeanbourquin, P., 1991b. Ultrahelvétique et mélanges sur le dos des nappes helvétiques des Diablerets et du Wildhorn. Bull. Soc. Frib. Sci. Nat. 80, 76-104.

Jeanbourquin, P., 1992. Les mélanges suprahelvétiques dans le synclinal de Thônes (Massifs subalpins, Haute-Savoie, France). Une nouvelle hypothèse de travail. Arch. Sci. Phys. Nat. Genève 45, 109-126.

Jeanbourquin, P., 1994. Early deformation of Ultrahelvetic mélanges in the Helvetic nappes (Western Swiss Alps). J. Struct. Geol. 16, 1367-1383.

Jeanbourquin, P., Burri, M., 1991. Les métasédiments du Pennique inférieur dans la région de Brigue-Simplon. Lithostratigraphie, structure et contexte géodynamique dans le bassin valaisan. Eclogae Geol. Helv. 84, 463-481.
Jeanbourquin, P., Kindler, P., Dall'Agnolo, S., 1992. Les mélanges des Préalpes internes entre Arve et Rhône (Alpes occidentales franco-suisses). Eclogae Geol. Helv. 85, 59-83.

Kerckhove, C., 1969. La zone du flysch dans les nappes de l'Embrunais-Ubaye. Géol. Alp. 45, 5-204.

Kerckhove, C., Lereus, C., 1987. Le détritisme des black-shales crétacés du domaine subbriançonnais durancien, nouvelles données tirées du massif du Morgon. Un olistolite à matériel triasique issu d'un diapir synsédimentaire. Géol. Alp. Mém. 13, 235-245.

Keusen, H.R., 1972. Mineralogie und Petrographie des metamorphen Ultramafit-Komplexes vom Geisspfad (Penninische Alpen). Schweiz. Mineral. Petrogr. Mitt. 52, 385-478.

Kindler, P., 1988. Géologie des wildflyschs entre Arve et Giffre (Haute-Savoie, France). Thèse 6, Univ. Genève, 134 pp.

Kirshner, D.L., Cosca, M.A., Masson, H., Hunziker, J.C., 1996. Staircase ${ }^{40} \mathrm{Ar} /{ }^{39} \mathrm{Ar}$ spectra of fine grained mica. Timing and duration of deformation and empirical constraints on argon diffusion. Geology 24, 747-750.

Klitgord, K.D., Schouten, H., 1986. Plate kinematics of the Central Atlantic. In: Vogt, P.R., Tucholke, B.E. (Eds.), The Western North Atlantic Region, Vol. M. Geological Society of America, Boulder, CO, pp. 351-377.

Lempicka-Münch, A., Masson, H., 1993. Dépôts d'âge tertiaire de la nappe ultrahelvétique du Sex Mort entre la Simme et Adelboden (Préalpes). Bull. Soc. Vaudoise Sci. Nat. 82, 369389

Lihou, J.C., 1996. Stratigraphy and sedimentology of the Sardona unit, Glarus Alps. Upper Cretaceous/middle Eocene deep marine flysch sediments from the Ultrahelvetic realm. Eclogae Geol. Helv. 89, 721-752.

Lihou, J.C., Allen, P.A., 1996. Importance of inherited rift margin structures in the early north Alpine foreland basin, Switzerland. Basin Res. 8, 425-442.

Liniger, M., 1992. Der ostalpin-penninische Grenzbereich im Gebiet der nördlichen Margna-Decke (Graubünden, Schweiz). Ph.D. Thesis 9769, Mitt. Geol. Inst. ETH Univ. Zürich, 186 pp.

Loup, B., 1992. Mesozoic subsidence and stretching models of the lithosphere in Switzerland (Jura, Swiss Plateau and Helvetic realm). Eclogae Geol. Helv. 85, 541-572.

Löw, S., 1987. Die tektono-metamorphe Entwicklung der nördlichen Adula-Decke. Beitr. Geol. Karte Schweiz 161, 84 pp.

Malod, J.A., Mauffret, A., 1990. Iberian plate motion during the Mesozoic. Tectonophysics 184, 261-278.

Mancktelow, N., 1985. The Simplon line. A major displacement zone in the western Lepontine Alps. Eclogae Geol. Helv. 78 (1), 73-96.

Marchant, R.H., 1993. The underground of the Western Alps. Mém. Géol. (Lausanne) 15, 137 pp.

Marchant, R.H., Stampfli, G.M., 1997a. Subduction of continental crust in the Western Alps. Tectonophysics 269, 217-235.

Marchant, R.H., Stampfli, G.M., 1997b. Crustal and lithospheric structures of the Western Alps: geodynamic significance. In: Pfiffner, O.A., Lehner, P., Heitzman, P.Z., Mueller, S., Steck, 
A. (Eds.), Deep Structure of the Swiss Alps - Results from NRP 20. Birkhaüser AG, Basel, pp. 326-337.

Markley, M., Teyssier, C., Cosca, M., 1995. Deformation vs. cooling ages: the application of the ${ }^{40} \mathrm{Ar} /{ }^{39} \mathrm{Ar}$ method to synkynematic white micas. Geol. Soc. Am. Annu. Mtg., A-217.

Markley, M., Teyssier, C., Cosca, M., Caby, R., Hunziker, J.C., Sartori, M., 1998. Alpine deformation and ${ }^{40} \mathrm{Ar} /{ }^{39} \mathrm{Ar}$ geochronology of synkynematic white micas in the SiviezMischabel Nappe, western Penninic Alps, Switzerland. Tectonics 17 (3), 407-425.

Marquer, D., 1991. Structures et cinématique des déformations alpines dans le granite de Truzzo (Nappe de Tambo, Alpes centrales suisses). Eclogae Geol. Helv. 84 (1), 107-123.

Marquer, D., Baudin, T., Peucat, J.J., Persoz, F., 1994. Rb-Sr micas ages in the Alpine shear zones of the Truzzo granite. The timing of the Tertiary Alpine P-T-deformations in the Tambo nappe (Central Alps, Switzerland). Eclogae Geol. Helv. 87 (1), 225-240.

Marquer, D., Challandes, N., Baudin, Th., 1996. Shear zone patterns and strain partitioning at the scale of a Pennine nappe. The Suretta nappe (eastern Swiss Alps). J. Struct. Geol. 18 (6), 753-764.

Marthaler, M., Stampfli, G.M., 1989. Les Schistes lustrés à ophiolites de la nappe du Tzaté. Un ancien prisme d'accrétion issu de la marge active appulienne. Schweiz. Mineral. Petrogr. Mitt. 69, 211-216

Masson, H., 1976. Un siècle de géologie dans des Préalpes de la découverte des nappes à la recherche de leur dynamique. Eclogae Geol. Helv. 69, 527-575.

Masson, H., Baud, A., Escher, A., Gabus, J., Marthaler, M., 1980. Compte rendu de l'excursion de la Société Géologique Suisse. Coupe Préalpes-Helvétique-Pennique en Suisse occidentale. Eclogae Geol. Helv. 73, 331-349.

Massonne, H.J., Schreyer, W., 1987. Phengite geobarometry based on the limiting assemblage with K-feldspar, phlogopite, and quartz. Contrib. Mineral. Petrol. 96, 212-224.

Matter, A., Homewood, P., Caron, C., Rigassi, D., van Stuijvenberg, J., Weidmann, M., Winkler, W., 1980. Flysch and molasse of western and central Switzerland. In: Trümpy, R. (Ed.), Geology of Switzerland. 26th Int. Geol. Congr. Part B. Geological excursions, excursion IV. Wepf, Basel, pp. 261293.

Mayerat, A.M., 1994. Analyse structurale de la zone frontale de la nappe de Tambo (Pennique, Grisons, Suisse). Mat. Carte Géol. Suisse NS 165, 68 pp.

Mégnien, C., 1980. Synthèse géologique du bassin de Paris. Mém. BRGM, vols. 101, 102, 103, 467 pp.

Menkweld-Gfeller, U., 1997. Die Bürgen-Fm, und die Klimsenhorn-Fm. Formelle Definition zweier lithosstratigraphischer Einheiten des Eozäns der helvetischen Decken. Eclogae Geol. Helv. 90, 245-261.

Merle, O., 1994. Syn-convergence exhumation of the Central Alps. Geodin. Acta 7, 129-138.

Merle, O., Cobbold, P., Schmid, S., 1989. Tertiary kinematics in the Lepontine dome. Geol. Soc. London Spec. Publ. 45, 113-134.
Mettraux, M., 1989. Sédimentologie, paléotectonique et paléoocéanographie des Préalpes Médianes (Suisse Romande) du Rhétien au Toarcien. Ph.D. Thesis 947, Univ. Fribourg.

Mettraux, M., Mosar, J., 1989. Tectonique alpine et paléotectonique liasique dans les Préalpes Médianes en rive gauche du Rhône. Eclogae Geol. Helv. 82, 517-540.

Meyre, Ch., Puschnig, A.R., 1993. High-pressure metamorphism and deformation at Trescolmen, Adula nappe, Central Alps. Schweiz. Mineral. Petrogr. Mitt. 73 (2), 277-285.

Michard, A., Chopin, C., Henry, C., 1993. Compression versus extension in the exhumation of the Dora-Maira coesite bearing unit, Western Alps, Italy. Tectonophysics 221, 173-193.

Milnes, A.G., 1974. Structure of the Pennine zone (central Alps); a new working hypothesis. Geol. Soc. Am. Bull. 85, 17271732.

Milnes, A.G., Schmutz, H.U., 1978. Structure and history of the Suretta nappe (Pennine zone, Central Alps). A field study. Eclogae Geol. Helv. 71 (1), 19-33.

Monié, P., 1985. La méthode ${ }^{39} \mathrm{Ar}-{ }^{40} \mathrm{Ar}$ appliquée au métamorphisme alpin du Mont Rose (Alpes occidentales). Chronologie détaillée depuis 110 Ma. Eclogae Geol. Helv. 78, 487-516.

Montigny, R., Azambre, B., Rossy, M., Thuizat, R., 1986. KAr study of Cretaceous magmatism and metamorphism in the Pyrenees; age and length of rotation of the Iberian Peninsula. Tectonophysics 129, 257-273.

Moreau, M.G., Canérot, J., Malod, J.-A., 1992. Paleomagnetic study of Mesozoic sediments from the Iberian Chain (Spain) suggestions for Barremian remagnetization and implications for the rotation of Iberia. Bull. Soc. Géol. Fr. 163, 393-402.

Mosar, J., 1988. Métamorphisme transporté dans les Préalpes. Schweiz. Mineral. Petrogr. Mitt. 68, 77-94.

Mosar, J., 1989. Déformation interne dans les Préalpes Médianes (Suisse). Eclogae Geol. Helv. 82, 765-793.

Mosar, J., 1994. Géologie structurale à l'est de Montreux (Préalpes médianes plastiques, Suisse). Eclogae Geol. Helv. 87, 11-32.

Mosar, J., 1997. Folds and thrust in the Préalpes Médianes plastiques romandes. Bull. Soc. Vaudoise Sci. Nat. 84, 347384

Mosar, J., Borel, G., 1992. Paleostress from the Préalpes médianes (Switzerland). Ann. Tectonicae 6, 115-133.

Mosar, J., Stampfli, G.M., Girod, F., 1996. Western Préalpes médianes; timing and structure. A review. Eclogae Geol. Helv. 89, 389-425.

Nievergelt, P., Liniger, M., Froitzheim, N., Mählmann, R.F., 1996. Early to mid Tertiary crustal extension in the Central Alps. the Turba mylonite zone (Eastern Switzerland). Tectonics 15 (2), 329-340.

Nussbaum, Ch., Marquer, D., Biino, G., 1998. Two subduction events in a polycyclic basement. example of Alpine and preAlpine high pressure in the Alps (Suretta nappe, Swiss Eastern Alps). J. Metamorph. Geol, in press.

Oberhänsli, R., Hunziker, J.C., Martinotti, G., Sten, W.B., 1985. Geochemistry, geochronology and petrology of Monte $\mathrm{Mu}$ crone. An example of eo-alpine eclogitisation of Permian granitoids in the Sesia Lanzo zone, western Alps, Italy. Chem. Geol. 52, 165-184. 
Odin, G.-S., Odin, C., 1990. Echelle numérique des temps géologiques, mis à jour, 1990. Géochronique 35, 12-23.

Olivet, J.-L., 1996. La cinématique de la plaque Ibérique. Bull. Rech. Explor. Elf-Aquitaine 20, 131-195.

Pastorelle, S., Martinotti, G., Piccardo, G.B., Rampone, E., Scambelluri, M., 1995. The geisspfad complex and its relationships with the Monte Leone Nappe (lower Pennine region, Western Alps). In: Polino, R., Sacchi, R. (Eds.), Rapporti Alpi-Appennino e Guide alle Escursioni. XIV, Scritti e Documenti/Acc. Naz. Scienze, Peveragno (CN), pp. 349-358.

Peybernès, B., 1976. Le Jurassique et le Crétacé inférieur des Pyrénées franco-espagnoles. Thèse 696, Univ. Paul-Sabatier, Toulouse, $459 \mathrm{pp}$

Peybernès, B., Souquet, P., 1984. Basement blocks and tecto-sedimentary evolution in the Pyrenees during Mesozoic times. Geol. Mag. 121, 397-405.

Pfiffner, O.A., 1986. Evolution of the north Alpine foreland basin in the Central Alps. Int. Assoc. Sedimentol. Spec. Publ. 8, 219-228.

Pfiffner, O.A., 1990. Crustal shortening of the Alps along the EGT profile. In: Freeman, R., Giere, P., Müller, St. (Eds.), The European Geotraverse. Intergr. Studies. European Science Foundation, pp. 255-262.

Pfiffner, O.A., Frei, W., Finckh, P., Valasek, P., 1988. Deep seismic reflection profiling in the Swiss Alps. Explosion seismology results for line NFP 20-East. Geology 16, 987-990.

Pfiffner, O.A., Klaper, E.M., Mayerat, A.M., Heitzmann, P., 1990a. Structure of the basement-cover contact in the Swiss Alps. Mém. Soc. Géol. Suisse 1, 247-262.

Pfiffner, O.A., Frei, W., Valasek, P., Stauble, M., Levato, L., Dubois, L., Schmid, S.M., Smithson, S.B., 1990b. Crustal shortening in the Alpine orogen. Results from deep seismic reflection profiling in the eastern Swiss Alps line NFP 20-east. Tectonics 9 (6), 1327-1355.

Philip, J., Masse, P.J.-L., Machhour, L., 1987. L'évolution paléogéographique et structurale du front de chevauchement nord-toulonnais (Basse-Provence occidentale, France). Bull. Soc. Géol. Fr. 8, 541-550.

Plancherel, R., 1979. Aspects de la déformation en grand dans les Préalpes médianes plastiques entre Rhône et Aar. Eclogae Geol. Helv. 72, 145-214.

Plancherel, R., 1990. Les Préalpes du Chablais — Présentation générale. In: Charollais, J., Badoux, H. (Eds.), Suisse Lémanique Pays de Genève et Chablais. Guides Géologiques Régionaux. Masson, Paris, pp. 183-190.

Plasienka, D., 1996. Mid-Cretaceous (120-80 Ma) orogenic processes in the central Western Carpathians. Brief review and interpretation of data. Slovak Geol. Mag. 3-4, 319-324.

Platt, J.P., 1993. Exhumation of high-pressure rocks. A review of concepts and processes. Terra Nova 5, 119-133.

Poinssot, C., Goffé, B., Toulhoat, P., 1997. Geochemistry of the Triassic-Jurassic Alpine continental deposits. Origin and geodynamic implications. Bull. Soc. Géol. Fr. 168, 287-300.

Puga, E., Diaz de Federico, A., Demant, A., 1995. The eclogitized pillows of the Betic Ophiolitic Asoociation. relics of the Tethys Ocean floor incorporated in the Alpine chain after subduction. Terra Nova 7, 31-43.
Purdy, J.W., Jäger, E., 1976. K-Ar ages on rock-forming minerals from the Central Alps. Mem. Ist. Geol. Mineral. Univ. Padova 30, 32 pp.

Python-Dupasquier, C., 1990. La Formation de l'Intyamon (Crétacé moyen) des Préalpes médianes romandes. Ph.D. Thesis 978, Univ. Fribourg, 197 pp.

Ratschbacher, L., Neubauer, F., 1989. West-directed décollement of Austro-Alpine cover nappes in the eastern Alps. Geometrical and rheological considerations. In: Coward, M.P., Dietrich, D., Park, R.G. (Eds.), Alpine Tectonics. Geol. Soc. London Spec. Publ. 45, 243-264.

Reinecke, T., 1991. Very high pressure metamorphism and uplift of coesite bearing metasediments from the Zermatt Saas zone, Western Alps. Eur. J. Mineral. 3, 7-17.

Rosenberg, C., Berger, A., Davidson, C., Schmid, S.M., 1994. Messa in posto del plutone di Masino-Bregaglia, Alpi centrali. Atti Tic. Sci. Terra 1, 31-39.

Rosenberg, C., Berger, A., Schimd, S.M., 1995. Observation from the floor of a granitoid pluton. Inferences on the driving force of final emplacement. Geology 23, 443-446.

Rowley, D.B., Lottes, A.L., 1988. Plate-kinematic reconstructions of the North Atlantic and Artic. Late Jurassic to Present. Tectonophysics 155, 73-120.

Sartori, M., 1987. Blocs basculés briançonnais en relation avec leur socle originel dans la nappe de Siviez-Mischabel (Valais, Suisse). C. R. Seances Acad. Sci. Paris, Sér. 2 305, 999-1005.

Sartori, M., 1990. L'unité du Barrhorn (Zone Pennique, Valais, Suisse). Mém. Géol. (Lausanne) 6, 1-156.

Sartori, M., Marthaler, M., 1994. Exemples de relations socle-couverture dans les nappes penniques du Val d'Hérens. Schweiz. Mineral. Petrogr. Mitt. 74, 503-509.

Schaerer, G., 1974. Geologisch-strukturelle Untersuchungen des unteren Val Madris and Val di Lei. Diplomarb. ETH Zürich.

Schardt, H., 1884. Etudes géologiques sur le Pays d'Enhaut vaudois. Bull. Soc. Vaudoise Sci. Nat. 20, 1-183.

Schardt, H., 1893. Sur l'origine des Préalpes romandes. Arch. Sci. Phys. Nat. Genève 3, 570-583.

Schardt, H., 1898. Les régions exotiques du versant Nord des Alpes Suisse. Préalpes du Chablais et du Stockhorn et les Klippes. Bull. Soc. Vaudoise Sci. Nat. 34, 113-219.

Schlunegger, F., Matter, A., Burbank, D.W., Klaper, E.M., 1997. Magnetostratigraphic contraints on relationships between evolution of the central Swiss Molasse basin and Alpine orogenic events. Geol. Soc. Am. Bull. 109, 225-241.

Schmid, S.M., Froitzheim, N., 1993. Oblique slip and block rotation along the Engadine line. Eclogae Geol. Helv. 86 (2), 569-593.

Schmid, S.M., Zingg, A., Handy, M., 1987. The kinematics of movements along the Insubric Line and the emplacement of the Ivrea Zone. Tectonophysics 135, 47-66.

Schmid, S.M., Aebli, H.R., Heller, F., Zingg, A., 1989. The role of Periadriatic line in the tectonic evolution of the Alps. In: Coward, M.P., Dietrich, D., Park, R.G. (Eds.), Alpine Tectonics. Geol. Soc. London Spec. Publ. 45, 153-171.

Schmid, S.M., Rück, P., Schreurs, G., 1990. The significance of the Schams nappes for the reconstruction of the paleotectonic and orogenic evolution of the Penninic zone along the NFP 
20-East traverse (Grisons, Eastern Switzerland). Mém. Soc. Géol. Suisse 1, 263-287.

Schmid, S.M., Pfiffner, O.A., Froitzheim, N., Schönborn, G., Kissling, E., 1996. Geophysical-geological transect and tectonic evolution of the Swiss-Italian Alps. Tectonics 15 (5), 1036-1064

Schmid, S.M., Pfiffner, O.A., Schreurs, G., 1997. Rifting and collision in the Penninic zone of eastern Switzerland. In: Pfiffner, O.A., Lehner, P., Heitzman, P.Z., Mueller, S., Steck, A. (Eds.), Deep Structure of the Swiss Alps - Results from NRP 20. Birkhäuser AG, Basel, pp. 160-185.

Schreurs, G., 1993. Structural analysis of the Schams nappes and adjacent tectonic units. Implications for the orogenic evolution of the Penninic zone in Eastern Switzerland. Bull. Soc. Géol. Fr. 164 (3), 425-435.

Schweigl, J., Neubauer, F., 1997. Northern Calcareous Alps structural evolution. Eclogae Geol. Helv. 90, 303-324.

Septfontaine, M., 1983. Le Dogger des Préalpes médianes suisses et françaises (Stratigraphie, évolution paléogéographique et paléotectonique). Mém. Soc. Helv. Sci. Nat. 97, 1-121.

Septfontaine, M., 1995. Large scale progressive unconformities in Jurassic strata of the Prealps $\mathrm{S}$ of lake Geneva. Interpretation as synsedimentary inversion structures; paleotectonic implications. Eclogae Geol. Helv. 88, 553-576.

Sharp, Z.D., Essene, E.J., Hunziker, J.C., 1993. Stable isotope geochemistry and phase equilibria of coesite bearing whiteschist, Dora Maira Massif, western Alps. Contrib. Mineral. Petrol. 114, 1-12.

Sibuet, J.-C., Colette, B.J., 1991. Triple junctions of Bay of Biscay and North Atlantic. New constraints on the kinematic evolution. Geology 19, 522-525.

Simo, A., 1986. Carbonate platform depositional sequences, upper Cretaceous, south-central Pyrenees (Spain). Tectonophysics $129,205-231$.

Sinclair, H.D., 1996. Plan view curvature of foreland basins and its implications for the paleostrength of the lithosphere underlying the western Alps. Basin Res. 8, 173-182.

Sinclair, H.D., 1997. Tectonostratigraphic model for underfilled peripheral foreland basins: an Alpine perpspective. Geol. Soc. Am. Bull. 109, 324-346.

Spakman, W., van der Lee, S., van der Hilst, R., 1993. Travel time tomography of the European Mediterranean-mantle down to $1400 \mathrm{~km}$. Phys. Earth Planet. Inter. 79, 3-74.

Spring, L., Reymond, B., Masson, H., Steck, A., 1992. La nappe du Lebendun entre Alte Kaserne et le Val Cairasca (massif du Simplon); nouvelles observations et interprétations. Eclogae Geol. Helv. 85, 85-104.

Srivastava, S.P., Tapscott, C.R., 1986. Plate kinematics of the North Atlantic. In: Vogt, P.R., Tucholke, B.E. (Eds.), The Western North Atlantic Region. The Geology of North America, Geological Society of America, Boulder, CO, pp. 379404.

Srivastava, S.P., Verhoef, J., 1992. Evolution of Mesozoic sedimentary basins around the North Central Atlantic. A preliminary plate kinematic solution. In: Parnell, J. (Ed.), Basins on the Atlantic Seabord. Geol. Soc. London Spec. Publ. 62, 397-420.
Srivastava, S.P., Roest, W.R., Kovacs, L.C., Oakay, G., Lévesque, S., Verhoef, J., Macnab, R., 1990. Motion of Iberia since the Late Jurassic. Results from detailed aeromagnetic measurements in the Newfoundland Basin. Tectonophysics 184, 229260.

Stampfli, G.M., 1993. Le Briançonnais, terrain exotique dans les Alpes? Eclogae Geol. Helv. 86, 1-45.

Stampfli, G.M., 1994. Exotic terrains in the Alps. A solution for a single Jurassic ocean. Schweiz. Mineral. Petrogr. Mitt. 74, 449-452.

Stampfli, G.M., 1996. The Intra-Alpine terrain. A Paleotethyan remnant in the Alpine Variscides. Eclogae Geol. Helv. 89, 13-42.

Stampfli, G.M., Marchant, R.H., 1995. Plate configuration and kinematics in the Alpine region. In: Polino, R., Sacchi, R. (Eds.), Rapporti Alpi-Appennino e Guide alle Escursioni XIV, Scritti e Documenti/Acc. Naz. Scienze, Peveragno (CN), pp. $1-19$

Stampfli, G.M., Marchant, R.H., 1997. Geodynamic evolution of the Tethyan margins of the Western Alps. In: Pfiffner, O.A., Lehner, P., Heitzman, P.Z., Mueller, S., Steck, A. (Eds.), Deep Structure of the Swiss Alps - Results from NRP 20. Birkhaüser AG, Basel, pp. 223-239.

Stampfli, G.M., Marthaler, M., 1990. Divergent and convergent margins in the northwestern Alps. Confrontation to actualistic models. Geodin. Acta 4, 159-184.

Stampfli, G.M., Pillevuit, A., 1993. An alternative Permo-Triassic reconstruction of the kinematics of the Tethyan realm. In: Dercourt, J., Ricou, L.-E., Vrielinck, B. (Eds.), Atlas Tethys Palaeoenvironmental Maps. Explanatory Notes. Gauthier-Villars, Paris, pp. 55-62.

Stampfli, G.M., Marcoux, J., Baud, A., 1991. Tethyan margins in space and time. In: Channell, J.E.T., Winterer, E.L., Jansa, L.F. (Eds.), Paleogeography and Paleoceanography of the Tethys. Palaeogeogr., Palaeoclimatol., Palaeoecol. 87, 373-410.

Stampfli, G.M., Favre, P., Mosar, J., Pillevuit, A., Vannay, J.-C., 1998. Permo-Triassic evolution of the western Tethyan realm; the Neotethys/East-Mediterranean connection. In: Ziegler, P., Robertson, A.H.F., Cavazza, W. (Eds.), IGCP 369, Bull. Mus. Hist. Nat., Paris, in press.

Staub, R., 1916. Zur Tektonik der Südostlichen Schweizeralpen. Beitr. Geol. Karte Schweiz (N.F.) 46, 198 pp.

Staub, R., 1924. Der Bau der Alpen. Beitr. Geol. Karte Schweiz (N.F.) 52, $272 \mathrm{pp}$.

Staub, R., 1958a. Klippen decke und Zentralalpenbau. Beitr. Geol. Karte Schweiz (N.F.) 103, 184 pp.

Staub, R., 1958b. Tektonische Karte der schamser Decken und ihre Umgebung. Beitr. Geol. Karte Schweiz (N.F.) 103, 184 pp.

Steck, A., 1984. Structures de déformations tertiaires dans les Alpes centrales (transversale Aar-Simplon-Ossola). Eclogae Geol. Helv. 77 (1), 55-100.

Steck, A., 1990. Une carte des zones de cisaillement ductile des Alpes centrales. Eclogae Geol. Helv. 83, 603-627.

Steck, A., Hunziker, J., 1994. The Tertiary structural and thermal evolution of the Central Alps - compressional and exten- 
sional structures in an orogenic belt. Tectonophysics 238, 229-254.

Steffen, D., Jaques, C., Nydegger, T., Petroons, D., Wildi, W., 1993. La Brèche du Chablais à son extremité occidentale (Haute-Savoie, France). Sédimentologie, éléments stratigraphiques et interprétation paléogéographique. Eclogae Geol. Helv. 86, 543-568.

Steiner, C.W., Hobson, A., Favre, P., Stampfli, G.M., Hernandez, J., 1998. The Mesozoic sequence of Fuerteventura (Canary islands): witness of an Early to Middle Jurassic sea-floor spreading in the Central Atlantic. Geol. Soc. Am. Bull., in press.

Steinitz, G., Jäger, E., 1985. Rb-Sr and K-Ar studies on rocks from the Suretta nappe, Eastern Switzerland. Schweiz. Mineral. Petrogr. Mitt. 61, 121-131.

Steinmann, M., 1994a. Die nordpenninischen Bündnerschiefer der Zentralpen Graubünden. Tektonik, Stratigraphie und Beckenentwicklung. Ph.D. Thesis 10668, ETH Zürich, 221 pp.

Steinmann, M., 1994b. Ein Beckenmodell für das Nordpenninikum der Ostschweiz. Jahrb. Geol. Bundesanst. 137 (4), $675-721$.

Streiff, V., Jäckli, H., Neher, J., 1976. Atlas géologique de la Suisse $1: 25$ 000, 1235 Andeer, Comm. Géol. Suisse, 56.

Strohbach, H., 1965. Der mittlere Abschnitt der Tambodecke samt seiner mesozoischen Unterlage und Bedeckung. Mitt. Geol. Inst. ETH Univ. Zürich 38.

Thöni, M., Jagoutz, E., 1993. Isotopic constraints for eo-alpine high-P metamorphism in the Austroalpine nappes of the eastern Alps - bearing on Alpine orogenesis. Schweiz. Mineral. Petrogr. Mitt. 73, 177-189.

Thurow, J., 1987. Die kretazischen Turbiditserien im Gibraltarbogen. Bindeglied zwischen atlantischer und tethyaler Entwicklung. Ph.D. Thesis, Univ. Tübingen.

Thury, M., 1973. Der Lias der östlichen Préalpes médianes zwischen Boltigen und Spiez. Ph.D. Thesis, Univ. Bern.

Tilton, G.R., Schreyer, W., Schertl, H.P., 1989. Pb-Sr-Nd isotopic behavior of deeply subducted crustal rocks from the Dora Maira Massif, Western Alps, Italy. Geochim. Cosmochim. Acta 53, 1391-1400.

Torsvik, T.H., Smethurst, M.A., 1994. Geographic mapping and paleoreconstruction package (GMAP). Software description and examples of paleoreconstructions, vers. GMAP for Windows v. 1.0.

Trommsdorff, V., Dietrich, V., Flisch, M., Stille, P., Ulmer, P., 1990. Mid-Cretaceous, primitive magmatism in the Northern calcareous Alps. Significance for Austroalpine geodynamics. Geol. Rundsch. 79, 85-97.

Trümpy, R., 1960. Paleotectonic evolution of the Central and Western Alps. Geol. Soc. Am. Bull. 71, 843-908.

Trümpy, R., 1970. Aperçu général sur la géologie des Grisons. Bull. Soc. Géol. Fr. Suppl. 9, 330-394.

Trümpy, R., 1980. Geology of Switzerland, Part A. Wepf, Basel, 104 pp.

Trümpy, R., 1992. Ostalpen und Westalpen - Verbindendes und Trennendes. Jahrb. Geol. Bundesanst. 135, 875-882.

Venturini, G., 1995. Geology, geochemistry and geochronology of the inner central Sesia Zone (Western Alps, Italy). Mém. Géol. (Lausanne) 25, $183 \mathrm{pp}$.

Von Blanckenburg, F., 1990. Isotope geochemical and geochronological case studies of Alpine magmatism and metamorphism. The Bergell intrusion and Tauern Window. Unpubl. Diss. 9258, ETH Zürich.

Vuagnat, M., 1983. Les grès de Taveyannes et roches similaires. Vestiges d'une activité magmatique tardi alpine. Mem. Soc. Geol. Ital. 26, 39-53.

Wagreich, M., 1993. Subcrustal tectonic erosion in orogenic belts - a model for the late Cretaceous subsidence of the Northern Calcareous Alps (Austria). Geology 21, 941-944.

Weber, W., 1966. Zur geologie zwischen Chiavenna und Mesocco. Mitt. Geol. Inst. ETH Univ. Zurich (N.F.) 57, 248 pp.

Wei, W., Peleo-Alampay, A., 1993. Cenozoic nannofossils magnetostratigraphy. INA Newslett. 15, 1-23.

Weidmann, M., 1985. Géologie des Pléiades. Bull. Soc. Vaudoise Sci. Nat. 367, 11-20

Weidmann, M., 1992. Châtel-Saint-Denis, Feuille 92, notice. Serv. Hydrol. Géol. Nat., Bern (Switzerland).

Weidmann, M., Homewood, P., Caron, C., Baud, A., 1976. Réhabilitation de la Zone Submédiane des Préalpes. Eclogae Geol. Helv. 69, 265-277.

Weiss, H., 1949. Stratigraphie und Mikrofauna des Klippenmalm. Ph.D. Thesis, Univ. Zürich.

Wildi, W., 1983. La chaîne tello-rifaine (Algérie, Maroc, Tunisie) structure, stratigraphie et évolution du Trias au Miocène. Rev. Géogr. Phys. Géol. Dyn. 24, 201-297.

Wilhelm, O., 1921. Geologische Karte der Landchaft Schams und Profile. 1:50000. Beitr. Geol. Karte Schweiz, Spezialk. 114A, B.

Wilhelm, O., 1933. Geologie der Landschaft Schams (Graubünden). Beitr. Geol. Karte Schweiz N.F. 64, 1-32.

Winkler, W., Bernoulli, D., 1986. Detrital high-pressure/lowtemperature minerals in a late Turonian flysch sequence of the eastern Alps (western Austria). Implications for early Alpine tectonics. Geology 14, 598-601.

Winterer, E.L., Bosellini, A., 1981. Subsidence and sedimentation on Jurassic passive continental margin, southern Alps, Italy. Am. Assoc. Pet. Geol. Bull. 65, 394-417.

Wortel, M.J.R., Spakman, W., 1992. Structure and dynamics of subducted lithosphere in the Mediterranean region. Proc. K. Nederl. Akad. Wetensch. Ser. B 95, 325-347.

Yanev, Y., Bardintzeff, J.-M., 1997. Petrology, volcanology and metalogeny of Paleogene collision related volcanism of the eastern Rhodope. Terra Nova 9, 1-8.

Yilmaz, P.O., Norton, I.O., Leary, D., Chuchla, R.J., 1996. Tectonic evolution and paleogeography of Europe. In: Ziegler, P.A., Horvath, F. (Eds.), Structure and Prospect of Alpine Basins and Forelands. Mém. Mus. Natl. Hist. Nat., Peri-Tethys Memoir 2, pp. 47-59.

Zahner, P., Mosar, J., 1993. In: Résultats des recherches effectuées sur le site potentiel du Bois de la Glaive (Commune d'Ollon, VD). Cédra Rapport Technique 93, 1-54.

Ziegler, P.A., 1988. Evolution of the Arctic-North Atlantic and the Western Tethys. Am. Assoc. Pet. Geol. Mem. 43, 198 pp. 
Ziegler, P.A., 1990. Geological Atlas of Western and Central Europe (2nd ed.). Shell Int. Petroleum Mij., Den Haag, 239 pp.

Ziegler, P.A., Cloetingh, S., van Wees, J.-D., 1995. Dynamics of intra-plate compressional deformation. The Alpine foreland and other examples. Tectonophysics 252, 7-59.

Ziegler, W., 1956. Geologische Studien in den Flyschgebieten des Oberhalbsteins (Graubünden). Eclogae Geol. Helv. 49 (1),
$1-78$.

Zingg, A., Handy, M.R., Hunziker, J.C., Schmid, S.M., 1990. Tectonometamorphic history of the Ivrea zone and its relationship to the crustal evolution of the southern Alps. Tectonophysics 182, 169-192.

Zurflüh, E., 1961. Zur Geologie des Monte Spluga. Mitt. Geol. Inst. ETH Univ. Zürich 83. 